Portland State University

PDXScholar

\title{
Mangrove Enhancement as a Climate Change Adaptation Strategy in the Republic of the Marshall Islands (RMI): Potential Ecosystem Service Shifts Following Colonization
}

Andrew S. Harwood

Portland State University

Follow this and additional works at: https://pdxscholar.library.pdx.edu/mem_gradprojects

Part of the Environmental Indicators and Impact Assessment Commons, Environmental Monitoring Commons, and the Natural Resources Management and Policy Commons Let us know how access to this document benefits you.

\section{Recommended Citation}

Harwood, Andrew S., "Mangrove Enhancement as a Climate Change Adaptation Strategy in the Republic of the Marshall Islands (RMI): Potential Ecosystem Service Shifts Following Colonization" (2016). Master of Environmental Management Project Reports. 51.

https://pdxscholar.library.pdx.edu/mem_gradprojects/51

https://doi.org/10.15760/mem.53

This Project is brought to you for free and open access. It has been accepted for inclusion in Master of Environmental Management Project Reports by an authorized administrator of PDXScholar. Please contact us if we can make this document more accessible: pdxscholar@pdx.edu. 


\title{
Mangrove Enhancement as a Climate Change Adaptation Strategy in the Republic of the Marshall Islands (RMI): Potential Ecosystem Service Shifts Following Colonization
}

\section{Prepared for LIVING ISLANDS, NGO}

\author{
By: Andrew S. Harwood M.S.; M.E.M. Candidate
}

Portland State University, Department of Environmental Science and Management P.O. Box 751, Portland, OR 97207, USA

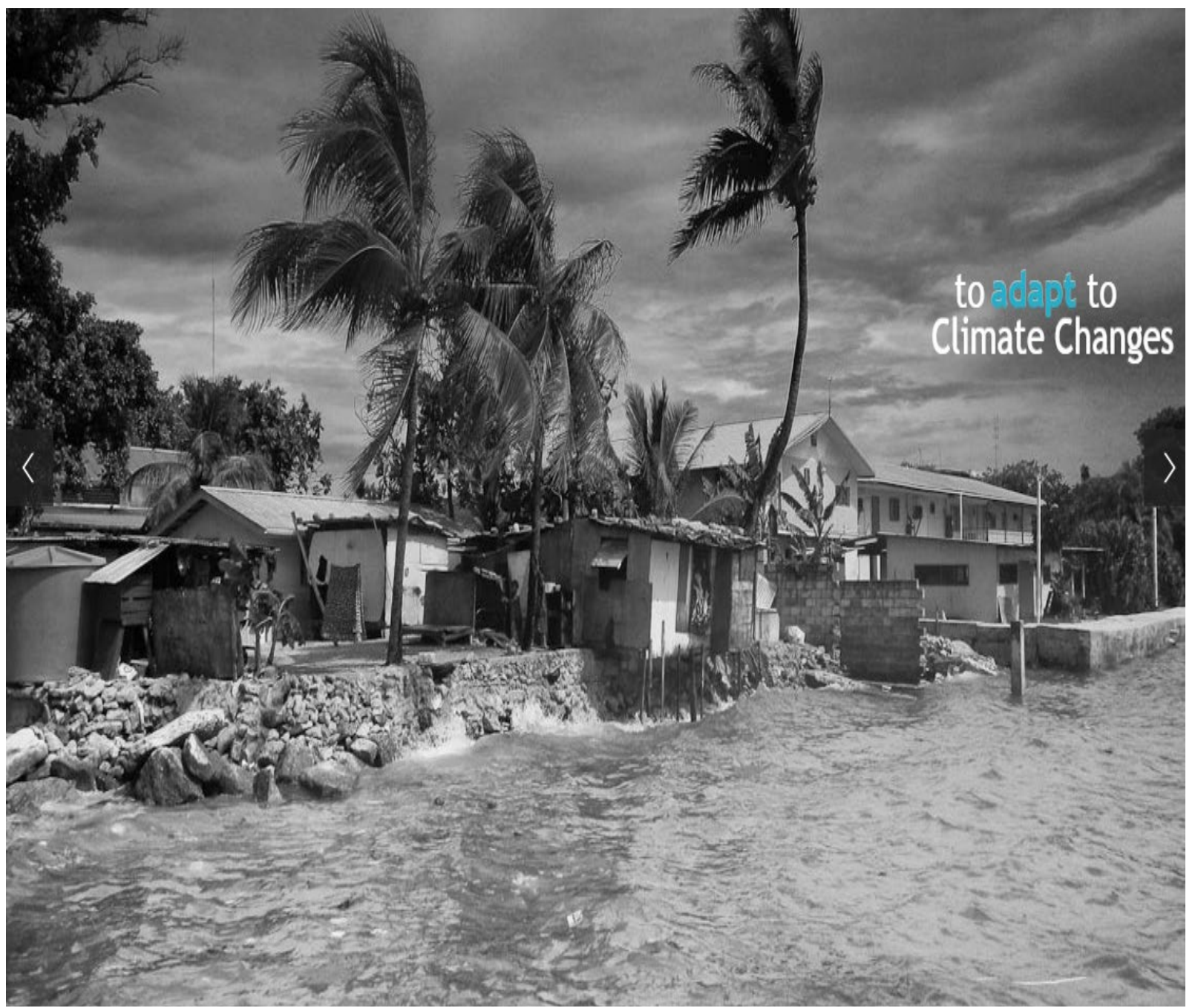

(LivingIslands.Org) 


\section{ABSTRACT}

The ability of Small Island Developing States (SIDS) and Pacific Island communities to adapt to the increasing sea-levels, storm surge, saltwater intrusion, and other threats posed by global climate change is critical to the survival of many of these local communities as well as their cultures (LivingIslands.org). One of the world's most striking examples of a nation at great risk is the Republic of the Marshall Islands (RMI) in the central Pacific Ocean. Due to a combination of factors, including the country's extremely low elevation above sea-level (an average of 2 meters) and lack of adequate structures to provide safety during extreme weather events, the RMI is expected to be severely impacted by the increased frequency and intensity of floods, droughts, coastal erosion, and elevated sea surface levels and temperatures predicted from global climate change models (IPCC, 2014).

The broad objectives of this project are to 1) collect and review some of the most up-todate scientific knowledge regarding the potential effects of introducing mangrove trees in local communities and ecosystems from around the globe and 2) to assist the Republic of the Marshall Islands in developing climate change adaptation (and natural resource management) strategies for the $21^{\text {st }}$ century. The standard ecosystem services framework (provisioning, regulating, supporting, and cultural ecosystem services) from the Millennium Ecosystem Assessment (MEA, 2005 ) is applied to discuss the potential environmental changes brought about by mangrove introductions.

The first specific goal of this project is to provide an evaluation of potential impacts and benefits associated with mangrove introductions by examining their influences in regions where mangroves are historically present versus historically absent. The scientific literature indicates a clear distinction between these case studies. Introduction of mangroves into regions where other mangrove species already exist (Similar Species Introductions) tends enhance pre-existing mangrove related ecosystem services. Conversely, Exotic Species Introductions of mangroves into regions lacking shoreline vascular plants like mangroves tends to have more negative impacts on local communities and ecosystems. This apparent distinction is used as a foundation for much of the future scenario discussions in this paper.

The second major goal of this project is to examine how mangrove introductions in the Republic of the Marshall Islands, specifically, may affect local ecosystem services. Only the 5 historically occurring mangrove species present in the RMI are recommended to be used in mangrove introduction efforts into new habitats/islands within the RMI.

However, care must be taken when generalizing any location specific impacts. Therefore the third goal of this project is to examine how several key ecological theories can help synthesize global lessons and guide future scientific research. Knowledge gaps in the fields of island biogeography, population genetics, invasive species ecology, etc. are highlighted as ways to advance basic science and provide baseline data for future comparative research.

The final goal of this project is to recommend specific actions to the Republic of the Marshall Islands regarding the introduction of mangroves as a strategy to combat the effects of climate change. This section of the report explores the likely changes to ecosystem services and the precautions to be heeded when introducing mangroves to outer atolls in the RMI. 


\section{INTRODUCTION}

Mangrove trees represent a diverse group roughly 55 species from over 20 genera of semiaquatic plants specifically adapted to thrive in salt water conditions up to, and sometimes exceeding, full strength sea water. Dense "mangle" or "mangrove forests/ecosystems" straddle shorelines and fill coastal depressions to provide tropical and subtropical coastal communities with a wide range of benefits, called ecosystem services. Documented services related to mangroves include enhancing coastal fisheries (Dorenbosch et al. 2004; Primavera, 2008), protecting coastal communities from extreme geologic and weather events like earthquake born tsunamis and hurricanes (Danielsen et al. 2005; Williams et al. 2007), mitigating coastal eutrophication and nutrient pollution from urban and agri/aquaculture systems (Bouchez et al. 2013; Krauss et al. 2008), promoting terrestrial and marine biological/genetic diversity while enhancing terrestrial/marine and benthic/pelagic coupling of nutrient cycles and aiding in soil formation (Nagelkerken et al. 2008), and finally, of equal importance, are the ways mangroves provide spiritual, recreational and educational opportunities for millions of people around the globe every day (Walters et al. 2008; Hergazy et al. 2002).

As newly introduced mangroves provide specific ecosystem services to coastal communities, including protection against coastal erosion (Perry and Berkeley, 2009; Allen, 1998), creation of habitat for commercially important fisheries (Langer and Lipps, 2006), and their use to reforest previously cleared coastal habitat for development or aquaculture (Liu et al. 2014), these same trees have also been shown to have some dramatic negative ecological, economic, and social consequences. This appears particularly evident in regions where mangroves have been introduced in large numbers (high propagule pressure), and into areas that did not historically have mangroves present (Exotic Species Introductions-ESI scenarios). Cited examples include loss of critical habitat for endangered shorebirds and anchialine pond species on the island of Oahu (Drigot et al. 2001), altered hydrologic flows resulting in drainage problems in coastal Pacific Island communities (Allen, 1998), root-caused mechanical deterioration of archeological sites and culturally important fishponds on the island of Moloka'i (Farber, 1997), and negatively impacted coastal aesthetics on the French Polynesian islands of Morea and Tahiti (Langer and Lipps, 2006).

As climate change impacts loom, many nations are looking for natural and cost effective ways to buffer shorelines, such as by planting intertidal vegetation including mangrove trees, and help protect coastal communities from sea level rise, storm surge and tsunami waves, while also providing additional ecosystem services for locals between extreme weather or geologic events. Although many nations are benefiting from the ecosystem services provided by mangrove introductions, a general trend arises through reviewing the scientific literature and case studies. Similar Species Introductions (SSI) into regions already containing mangroves tend to have more positive effects on local ecosystems and communities than Exotic Species Introductions (ESI) of mangroves into habitats where mangroves are not historically present. The SSI vs. ESI distinction serves as a thematic foundation for the synthesis of reviewed literature and provides an additional layer for understanding the complexities of dynamic ecosystem service shifts following mangrove introductions.

One nation considering expanding the populations of existing mangroves (SSI) to additional islands as an adaption strategy to global climate change is the Republic of the Marshall Islands. Republic of the Marshall Islands (RMI) consists of 29 atolls and 5 flat coral islands, divided into two main geographic chains. The Eastern (Sunrise) Branch or "Ratak" island chain and the Western (Sunset) Branch or " $\mathrm{Ra}^{-}$lik" island chain are found in the Pacific 
Ocean between roughly $160^{\circ}$ and $173^{\circ}$ longitude east and $4^{\circ}$ and $14^{\circ}$ latitude north.

Unfortunately, much of the world is mostly familiar with the Marshall Islands from their colonial wartime past, and the ongoing nuclear tests which began on Bikini Atoll back in World War II, and less familiar with its pristine coral reefs, proud maritime cultural, and the Traditional Ecological Knowledge (TEK) of the native Marshallese surviving on remote atolls for thousands of years. United States based NGOs and non-profit organizations such as Living Islands (The Community Partner for this project) work closely with multiple levels of the business and political communities in both the RMI and USA to "protect the inhabitants [of the Marshall Islands] against the loss of their lands and resources..." mandated first in July of 1947 (http://www.rmiembassyus.org)." The broad objective of this project is to increase the scientific understanding of how introducing mangroves can alter a wide range of ecosystem services along colonized coastlines. Relatively ecologically pristine outer atolls in the southern Marshall Islands, including Namdrik with a Ramsar sanctioned mangrove Wetland of International Importance, provide a unique research platform for exploring how expanding existing mangrove forests on Namdrik, and introducing these mangroves to nearby atolls, provides climate change and intertidal marine biologists a platform for long term ecological research. This is uniquely facilitated by the gracious assistance of Living Islands Executive Director Kianna Juda-Angelo, who holds maternally inherited land rights too many southern atolls including Namdrik. Living Islands projects are encourage community-led research projects which blend modern scientific methods with Traditional Ecological Knowledge (TEK) of local elders through a variety of projects in the RMI and USA, including the construction on a traditional Marshallese outrigger canoe at Portland State University (PSU) in 2015/16. This outrigger build demonstrated Living Islands ability engage all levels of society, as visitors to the outrigger build site ranged from daily students passing by to the a visit from the (then standing) President of the Republic of the Marshall Islands Christopher Loeak. Living Islands NGO has been asked to assist natural resource managers in the RMI in determining if mangrove introductions would provide a positive net benefit to Marshallese communities threatened by climate change related impacts.

\section{Project Goals}

This project's main goals are to 1) Examine the range of potential ecosystem service (MEA, 2005) shifts resulting from introducing mangroves in the Republic of the Marshall Islands. 2) Then develop a range of future scenarios based on hypothesized trajectories examine MEA ecosystem service category shifts following mangrove introductions into SSI and ESI habitats. This contrast allows for a more complete comparative foundation to 4) provide recommendations to Living Islands and natural resource managers in the RMI managers seeking cost effective climate change adaptation strategies. Finally 5) common ecological theories are referenced throughout to explore knowledge gaps and identify specific future research avenues.

The flowchart for this project, shown in Figure 1, explains how mangrove related shifts to ecosystem services are thematically divided into MEA ecosystem service categories and related to historical habitats through Similar Species Introduction vs. Exotic Species Introduction comparisons, and then key ecological theories are utilize to synthesize case-study conclusions from the global literature review to provide specific recommendations to the Marshallese regarding how to use mangrove introductions as a tool to enhance specific local ecosystem services with minimal negative impacts and specific monitoring recommendations. 


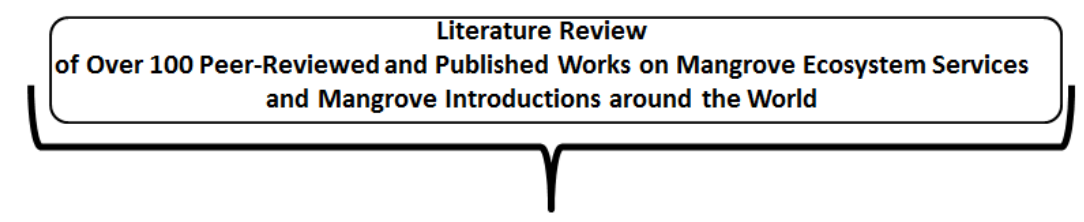

\section{Framework Used for Data Synthesis}

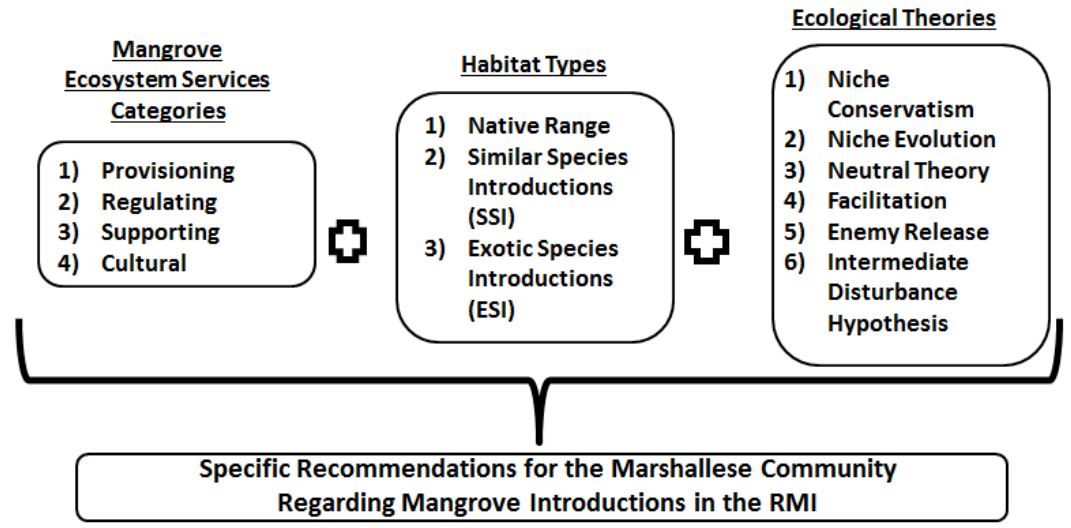

Figure 1: Logic model flowchart for this project illustrating how mangrove introduction literature is examined through three lenses: Ecosystem Services, Habitat Type, and Ecological Theories which are used to help synthesize and make recommendations about mangrove introduction in the RMI.

\section{METHODS AND THEORIES UTILIZED}

\section{Literature Review:}

While a body of work has described the benefits of mangroves within their native ranges, the scientific literature is severely deficient in examining the roles mangroves play when they are introduced into a new habitat. Following methods similar to those used by Simberloff and Von Holle (1999), a literature search through the Web of Science (ISI) Scientific Literature Database was conducted for the terms (mangrove*) AND (non-native OR non-indigenous OR alien OR invasive OR exotic) to collect as much peer reviewed research about mangrove colonizing new habitats as possible up to $2014 / 15$. When compared to a search for only the term "mangrove*" it was found that less than $2 \%$ of peer-reviewed mangrove related literature addressed them as being a non-native species. Even fewer of these addressed mangrove related shifts to local ecosystems and ecosystem service provisioning post-colonization. From the search results, the most relevant $100(+)$ articles, books, agency reports, and white papers from around the globe are collected and summarized herein as a foundation to investigate the complex topic of utilizing mangrove introductions as a climate change adaptation strategy for the Republic of the Marshall Islands (Figure 2). To address the wide range of possible shifts following mangle (mangrove forest) establishment, several standard and thematically familiar scientific theories (having predefined vocabulary for comparative purposes) were used to synthesize information from the global case studies. 


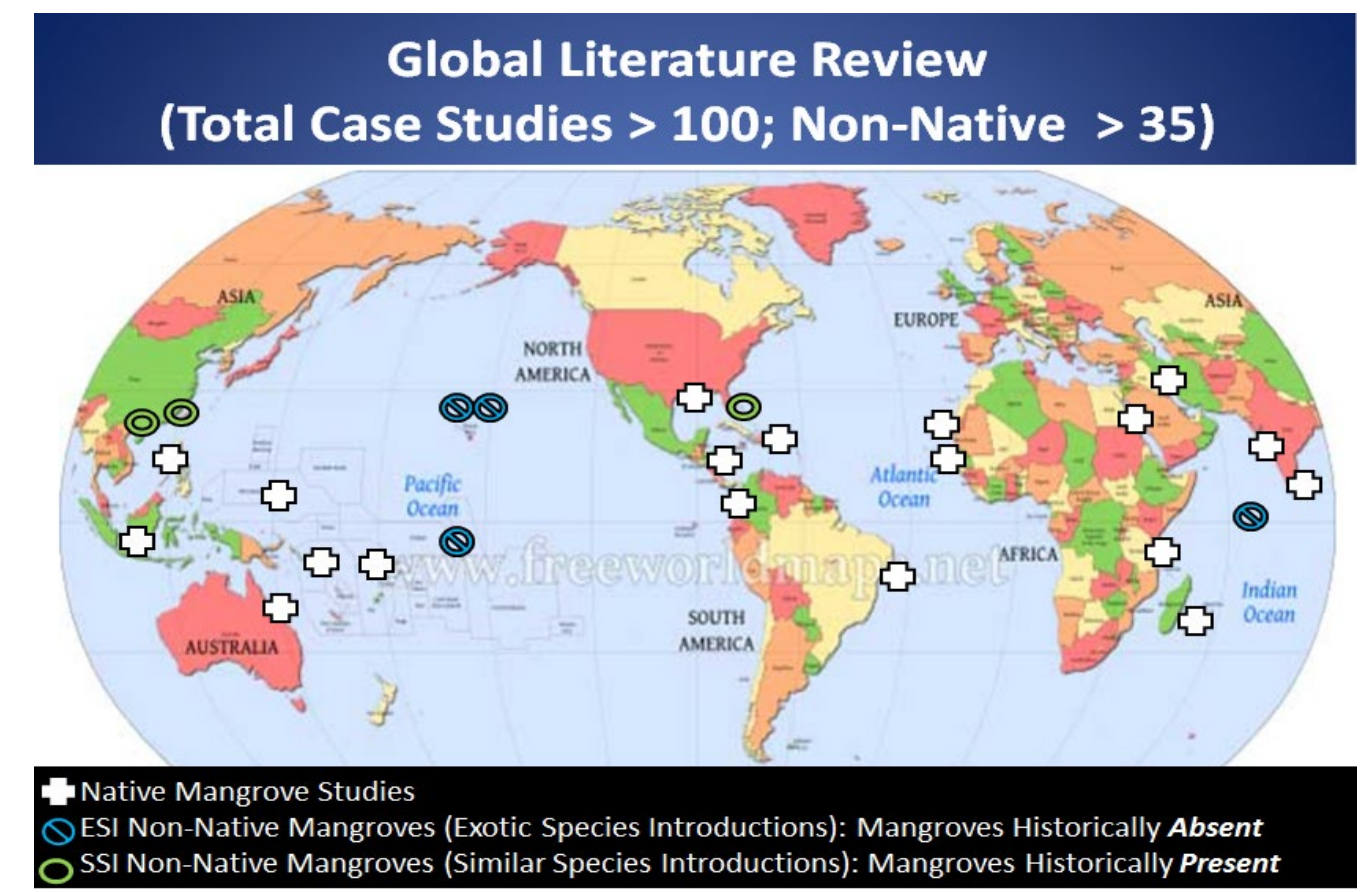

Figure 2: The geographic range of case studies examined during this project.

\section{Ecosystem Services:}

The standard Millennium Ecosystem Assessment (MEA, 2005) categories were used to discuss mangrove related ecosystem services in their native and introduced (ESI and SSI) ranges. These categories then provide a theoretical framework for exploring the wide range of shifts in ecosystem services that are possible following non-native mangrove colonization (MEA, 2005). The MEA classifies ecosystem services into four main categories:

\section{1) Provisioning services, which include direct and indirect} resources such as food and fuel harvested from mangrove ecosystems and adjacent habitats supported through biotic and abiotic connectivity with the mangle/mangrove ecosystem

2) Regulating services, including coastal protection from landward waves and sea level rise, seaward retention of terrestrial sediments, atmospheric carbon sequestration, cycling and removal of excess coastal nutrients including the breakdown of toxic pollutants through bioremediation.

3) Supporting services encompass a broad range of interconnected services ranging from the maintenance of biologically diverse communities and gene pools to the natural cycling of nutrients into biologically available forms and soil formation which couple adjacent ecosystems (biologically, nutritionally, hydrologically).

4) Cultural services which include the traditional, spiritual, aesthetic, recreational, and educational opportunities mangrove ecosystems provide for local communities to global eco-travelers. 
These four main ecosystem service categories were used to help understand some of the fundamental benefits mangroves provide to coastal communities in their native and non-native ranges (highlighted by the ESI/SSI dichotomy). Conclusions and predictions are then made regarding how mangrove introductions in the Republic of the Marshall Islands, specifically, may influence a broad suite of ecosystem services affecting human health and well-being. Global case studies and research are used to help identify key environmental shifts and general patterns; however, this is not a comprehensive review of all mangrove related ecosystem services. Reviews of a wider range of ecosystem services provided by native mangroves, and other historically occurring coastal vegetation, can be found in articles including Alongi (2002), Barbier et al. (2011), Brander et al. (2006), Conservation International (2008), Everard et al. (2014), Salem and Mercer (2012), Vo et al. (2012), and Walters et al. (2008), among many others. However, the most commonly cited mangrove ecosystem services were utilized during this project to emphasize specific comparisons and provide clear and accessible references for discussion makers and resource managers in the RMI. There are also a variety of ways which mangroves are valued by humans (Figure 3 for example), though valuation and weighing the importance of individual services is outside the scope of this project.

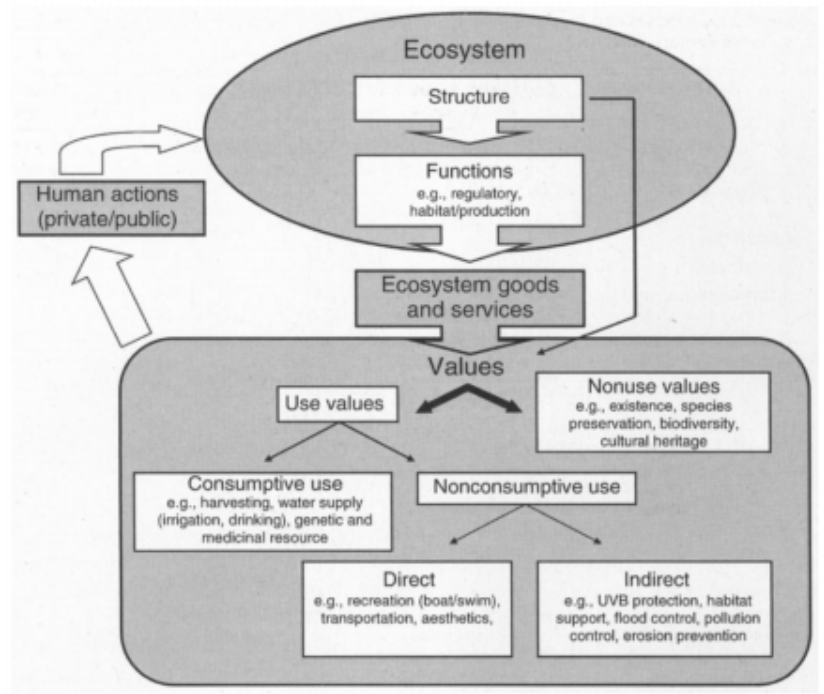

Figure 3: Diagram showing an ecosystem service valuation model examining how humans place different types of values on ecosystem services, and how human actions feedback to affect core ecosystem structure and function, which results in shifts in the ecosystem goods and services humans derive from local environments (from Barbier et al. (2011).

During the literature review, a clear distinction arose between documented shifts in ecosystem services following introductions of non-native mangroves into two main habitat types. Negative impacts from mangrove colonization seemed to be less severe in regions where similar species of mangrove have historically existed (Similar Species Introductions-SSI) versus locations where mangroves represent a species introduction (Exotic Species Introductions- ESI) into a habitat that did not contain mangroves historically. Due to the paucity of research on the effects of introduced mangroves in Coupled Human and Natural Systems (CHANS) (Marina et al. 2011), the predicted shifts in ecosystem services, and subsequently on human well-being, following mangrove introductions are largely theoretical. However, insights provided will serve as a foundation for management recommendations. Since proposed mangrove introductions in 
the Republic of the Marshall Islands include expanding the range of currently existing species, mangrove introductions in the RMI are considered SSI scenarios herein. The five diverse historic mangrove species, represented on multiple atolls in the RMI (Ellison, 2007), are discussed in more detail when examining the pairing of specific mangrove species with proposed introduction habitats.

In this project, mangrove related ecosystem services were identified in their native habitats and then compared to how these services are provided (or not) by non-native mangroves introduced into the two main habitat types (SSI and ESI) around the world (Figure 2). From this foundation, selective management recommendations regarding mangrove introductions in the RMI are examined. Since the topic of introduced species is complex, several ecological theories, which often predict contradictory outcomes, were also used to help guide the discussion in a contextually defined arena for comparative purposes herein.

\section{Synthesis Reference Frames and Ecological Theories Used:}

A clear distinction between how newly introduced mangroves interact with native ecosystems became evident during the literature review. Utilizing this inherent divide, an examination follows of how the local historic habitats and biological diversity influence new regional ecosystem service provisioning following non-native mangrove establishment. The literature indicates very different impacts when mangroves are introduced into areas that already have some mangrove species present, compared to introduction locations lacking historic mangroves. This divide between mangroves being Similar-Species-Introductions (SSI) vs. Exotic-Species-Introductions (ESI) is detailed in Figure 4 depicting habitat shifts as SSI vs. ESI coastlines become colonized. This comparison, made explicit, may help define general patterns of how ecosystem services shift as new species interact with established native species worldwide.

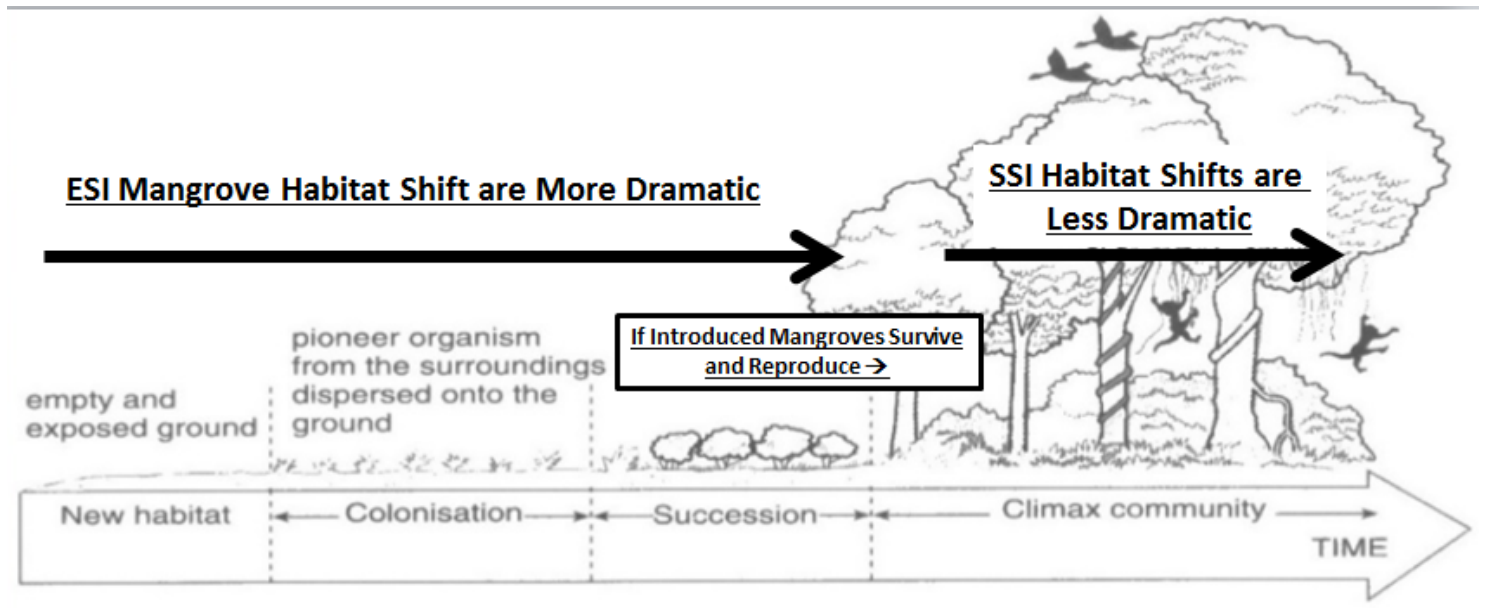

Figure 4: More dramatic shoreline habitat changes occur as open shoreline becomes colonized with vascular plants under ESI conditions. SSI introductions along historically vegetated coastline may undergo less dramatic shifts to reach an equilibrium or "climax community" (Modified from Slideshare.net).

Predictions about how recipient ecosystems may respond to mangrove colonization post lagphase, of commonly over 150 years (Simberloff and Van Holle 1999) are constructed by synthesizing information from previous case studies, and discussing them in the context of established ecological theories (including the often contradictory theories of niche conservatism 
vs. niche evolution in particular). Additional commonly explored ecological theories are used to frame a broad discussion about potential impacts of introducing mangroves to any location, while specific predictions are made regarding future ecosystem service provisioning in the RMI. Key knowledge gaps and uncertainties are highlighted alongside adaptive management recommendations for a range of ecological monitoring. The Republic of the Marshall Islands serves as an unprecedented "natural laboratory" for scientists and community participants to collect valuable baseline data on mangrove introductions is relatively contained systems. Collaborative data may then help other regions in the Pacific adapting to global climate change.

Previous research suggests that the functional roles of introduced species may primarily depend on whether or not similar native taxa currently fill their same niches (Hoopes and Hall, 2002). As previously explained, this aligns with the SSI vs. ESI dichotomy, where mangrove species colonize habitats where similar mangrove taxa currently/historically exist/ed vs. have not. Mangrove SSI scenarios may align with Neutral Theory, and the Hypothesis of Functional Equivalence, which state that introduced species with similar trophic and niche requirements as present/historic species are approximately identical in terms of birth, death, dispersal, and speciation rates (Hubbell, 2005). In other words, non-native introduced mangrove species should not have any immediate advantage over native mangrove species, if present, and may share similar functional roles in established ecosystems. Evidence supporting this comes from research investigating the introduction of SSI mangroves ranging from China (Chen et al. 2008; Pernetta et al. 2013; Xin et al. 2013) to the Gulf of Mexico (Fourqurean et al. 2010), where limited negative impacts/disservices have been reported, for example when examining variables such as carbon sequestration rates or exclusion of native mangrove taxa. However, Stochastic Niche Theory (Tillman, 2004), predicts non-natives will only be able to colonize if they are able to capitalize on resources which native species do not utilize (invasive only survive if they are superior competitors at the extreme physiological tolerances of native species).

Exotic Species Introductions (ESI), on the other hand, may change ecosystems into ecologically unique environments compared to historic conditions, and exert stronger influences on a broader range of ecosystem services than mangroves introduced into SSI habitats. Support for this conclusion comes from the growing body of research on Florida red mangrove (Rhizophora mangle) introductions over the past two decades, in the Hawaiian Islands in particular (Allen, 1998, Drigot et al. 2001; Garrison et al. 2002; Demopoulos et al. 2007; Fronda et al. 2008) though future research may be needed to validate this empirically (MacKenzie and Kryss, 2012.). This research indicates that $R$. mangle introductions into ESI regions can have dramatic negative effects on local ecosystems, including the exclusion of endangered shorebirds and Hawaiian monk seals for example (Allen, 1998), and many studies suggest that introducing $R$. mangle should be avoided in the Pacific whenever possible. One ecological theory supporting mangrove ESI scenarios is the Stochastic Niche Theory, which describes how under-utilized niche space in an environment may provide a narrow resource window for invasive species to gain a foothold which then allows them to become superior competitors under selective conditions (Tillman, 2004). Open sandy beach/rocky shorelines along weather-protected bays, where competition for space, light, and nutrients is often limited, provide under-utilized niche space which exotic mangroves may capitalize upon (Krauss et al. 2008; Li et al, 2011). Unfortunately, post-colonization, these overgrown areas can become dramatically altered from previously valued open coastlines. Thus, ESI non-native mangrove colonization may lead to social conflicts. $R$. mangle colonization (and subsequent removal) from the Wai'oppae Tidepools on Hawai'i ("The Big") Island, was a striking example of community tension associated with 
ESI mangrove management (Kobsa, 2010). Interestingly, some local community disapproval of the mangrove removal at the tide pools highlights how different people may value the same species for different reasons (new home buyers enjoying the privacy the mangroves provided vs. invasive species management groups protecting historic tide pools and native open coral lined coastlines (Per. Comm. w/ community residents and Malama O’Puna NGO, 2012).

The following two theories serve as a foundation for discussing many uncertainties associated with attempting to predict ecological change. The contrast between the ecological outcomes predicted under the theories of Niche Conservatism (NC) versus Niche Evolution (NE) requires diligent attention, and provide a solid vocabulary foundation for further thematic distinction. Niche conservatism (NC), which is supported by evidence from birds, mammals and butterflies (Peterson et al. 1999), predicts that rates of adaptation to conditions outside of a species fundamental (native) niche is slower than the extinction process. As a result, native species may die off before being able to adapt to rapidly changing ecological and environmental conditions; one of the fundamental concerns among climate change ecologists (IPCC, 2014). Mangrove establishment and spread has been shown to rapidly change coastal environments, ESI mangle on Molokai is a striking example as the coastal mangle has overgrown historic habitats and fishponds as the mangle has expanded over half a kilometer seaward restricting open-ocean access dramatically near Kaunakakai (Farber, 1997). In quickly forming ESI habitats, native biota may have a difficult time capitalizing on the finer grained terrestrial sediments, increased anoxic benthic conditions, and reduced hydrologic flows that non-native mangroves generate, resulting in potential exclusion of native biota from ESI mangrove habitats. Case studies supporting this in the Pacific range from endangered shorebird declines in the Hawaiian Islands to microscopic foraminifera community changes in French Polynesia (Allen, 1998; Langer and Lipps, 2006).

Niche evolution (NE), contrary to Niche Conservatism (NC), predicts native species may undergo behavioral or physiological changes to capitalize on novel environmental conditions or resources brought about by introduced species. Examples of Niche Evolution include endangered southwestern willow flycatchers (Empidonax traillii extimus) utilizing invasive Tamarisk trees (Tamarix ramosissima) for this bird's roosting sites (Davis et al. 2011), and native hawthorn flies (Rhagoletis pomonella) evolved to shift their emergence time to coincide with the fruiting of introduced apple trees (Malus domestica), resulting in the speciation of a new (reproductively isolated) type of fruit fly (Feder et al. 1988). Additionally, human communities may also capitalize on new ecosystem services provided by introduced species. One interesting ESI example includes constructing leis as necklaces in Hawaii from the more durable flowers of the introduced mangrove Bruguiera sexangula (Krauss and Allen, 2003).

Alongside these main theories of $\mathrm{NC}$ and $\mathrm{NE}$ are intertwining scientific theories to allow further thematic distinctions based on standard vocabulary. One of the most pertinent is the scientific theory of Facilitation. Facilitation helps explain the colonization of novel mangrove habitat by other species in a newly engineered ecosystem (Bruno, 2003). In the theory of facilitation, one species provides resources or niche space which another species then benefits from. Facilitation appears to have a larger affect in ESI habitats, such as in Hawaii where there is increasing evidence that mangroves may be facilitating the range expansion of other non-native aquatic species (Nakahara, 2007; Demopoulos et al. 2007) to terrestrial non-native cattle egrets, Indian mongoose, and Polynesian and black rats, which utilize dense mangrove habitats to escape predation and utilize propagules (mangrove seed pods) as a food source (Steele et al. 1999). 
The Enemy Release Hypothesis also provides a foundation for discussing the ability of ESI mangroves to quickly expand their range in habitats lacking native mangroves (Keane and Crawley, 2002). Mangrove propagule predation and host-specific pathogen/fungal diversity in non-native systems, for example, are dramatically reduced compared to native systems (Farnsworth and Ellison, 1997; Volmann-Kohlmeyer and Kohlmeyer, 1993). Additionally, survival rates of non-native ESI propagules on Oahu showed three times lower mortality rates compared to mangrove seed-pod predation in ecologically comparable native mangrove habitats on Tutuila Island, American Samoa (Steele et al. 1999). More examples of increased survival rates for ESI mangrove seedlings (propagules) and non-native species facilitation are utilized to illustrate uncertainties and the rapid rate of ecosystem change under specific conditions.

Utilizing the ESI vs. SSI distinction and ecological theories framed by the four main ecosystem service categories allows predictions to be made regarding shifts local communities may encounter following mangrove introductions. Many ecological shifts play out on time scales that exceed an individual restoration project, so insights gained from comparable case studies is used to help inform community stakeholders in the RMI. The negative consequences associated with mangrove introductions are also highlighted from the literature to provide managers with early warn signs about what types of undesired ecological shifts may occur and how to monitor for them following mangrove introductions.

\section{RESULTS and SYNTHESIS:}

Background on Mangrove Introductions:

Generally, exotic species of mangroves have been introduced (ESI) into new locations to provide specific ecosystem services. Global examples include the introduction of Rhizophora mangle to Moloka'i in the Pacific and Rhizophora mucronata to Rodrigues in the SE Indian Ocean; both introductions were designed to retain terrestrial sediments threatening to smother adjacent off-shore coral reefs (D'Iorio et al. 2007; Perry and Berkeley, 2009). ESI introductions have also been designed to enhance provisioning services, such as Rhizophora stylosa introductions to facilitate oyster aquaculture on the French Polynesian island of Moorea in 1937 (Taylor, 1979; Langer and Lipps, 2006). However, when introduced to fulfill a specific service, there are often unintended consequences, for better and worse (Figure 5: from Pinterest.com vs. Fronda et al. 2008).
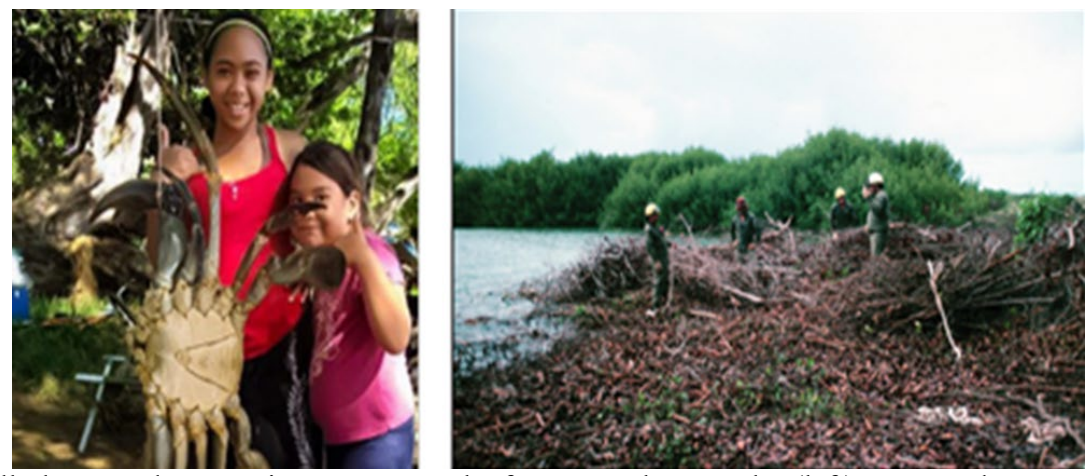

Figure 5: Locally harvested non-native Samoan crabs from mangle on Oahu (left) compared to mangrove removal efforts from historic fishpond walls on Hawaii Island near Honokohau (right) illustrate some of the complexities of shifting ecosystem services. 
Currently, there are fewer case studies examining Similar Species Introductions SSI of nonnative mangroves than ESI studies, as their impacts do not seem to be as readably noticeable. This could be due, in part, to the extended "lag-time" invasive species ecologist commonly note between establishment and perceived negative effects from non-native species. However, to begin a global comparison, SSI case studies ranging from non-indigenous mangrove introductions of the genus Sonneratia (Figure 6) into China in the 1990's for reforestation of tidal flats (Chen et al. 2008; Ren et al. 2009), to the escape of two mangrove species from botanical gardens in Florida: Bruguiera gymnorrhiza and Lumnitzera racemosa (Fourqurean et al. 2010). Interestingly, the rate of colonization and spread of non-native mangroves has occurred at different paces in various locations, but is typically faster in ESI than in SSI habitats which lack other competitive vascular plants (D'Iorio et al. 2007; Field et al. 2008 vs. Xin et al. 2013). The release of mangrove seedlings from their native predators (Enemy Release Hypothesis) is likely also accountable for rapid colonization rates observed in ESI systems (Field et al. 2008).

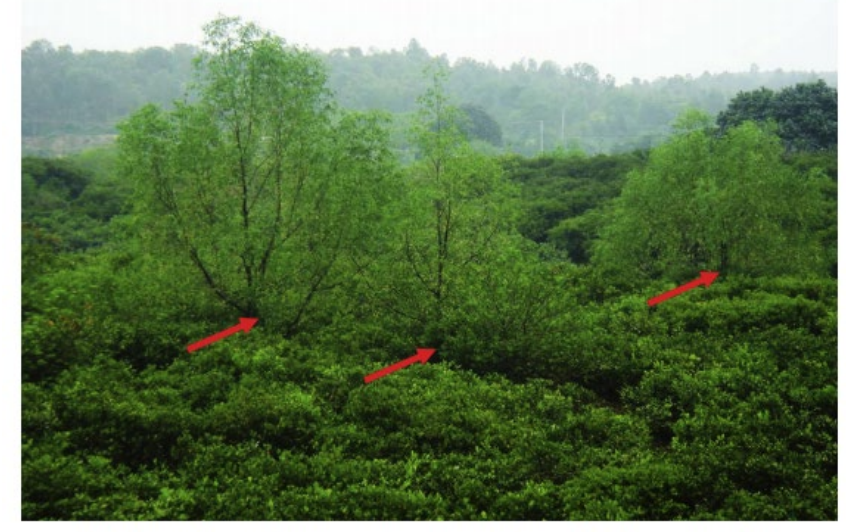

Fig. 2. An example of S. apetala invaded into natural mangrove forests in Zhanjiang National Mangrove Nature Reserve.

Figure 6: The larger, faster growing SSI mangrove S. apetala towers over native vegetation in southern China (from Ren et al. 2009).

Negative Impacts from Mangrove Introductions:

As their range expands, both ESI and SSI mangroves have the potential to exert pressures on native habitats and, in some cases, severely alter the native biological communities. In Hawaii, where no mangroves were historically present, ESI mangroves are currently overgrowing feeding and nesting grounds for 4 endangered species of Hawaiian shorebirds (Drigot et al. 2001), altering benthic macroinvertebrate assemblages (Demopoulos et al. 2007), exacerbating coastal flooding by reducing the efficiency of natural drainages (Allen, 1998), causing considerable damage to native Hawaiian fishponds as prop-roots break apart stone walls (Farber, 1997), and mangle impacts coastal aesthetics by producing unpleasant odors associated with hydrogen sulfide emissions from the anoxic substrates (Fry and Cormier, 2011), in addition to the increases in mosquitoes, giant orb spiders, and other biota which may limit human enjoyment of the mangle habitats in Hawaii. Examples of these negative impacts to tropical/subtropical island coastlines range geographically from Moloka'i in the Pacific Ocean (Molokai Bird Sanctuary: Dibbons-Young (2013), Molokai Sea Farms: Chaikin (2012), and Ka Honua Momona-Uncle Merv, Pers. Comm. 2012) to the island of Rodriguez in the Indian Ocean where mangroves have already significantly modified the sediments and benthic marine communities in 2 of 3 
introduction sites (Perry and Berkeley, 2009). On the island of Moorea, French Polynesia, solitary ESI mangrove trees often maintain a well-defined area around their base devoid of much vegetation; potentially indicating competitive exclusion of native taxa (Langer and Lipps, 2006). From sampling tiny marine protists known as foraminifera living in coastal sediments, Langer and Lipps also demonstrated that only specific native taxa tolerate the modified substrate conditions created by ESI mangrove trees. This exclusion may provide direct evidence for Niche Conservatism under some ESI conditions. Li et al. (2011), showed that competitive exclusion in SSI Sonneratia apetala mangrove forests near Hong Kong, for example, had significantly lower construction costs (glucose requirement for plant cell construction, NADPH, and ATP for energy) compared to native mangrove species. This [potentially] gives Sonneratia an advantage over natives and may enhance their ability to spread when introduced into new locations, leading to competition with native mangrove species. Surprising to some, this apparent advantage, has not shown to lead to non-native mangroves impacting the growth rates or biodiversity in existing mangrove forests. Experimental support from these case studies supports theories of Functional Equivalence and Neutral Theory in SSI ecosystems (Chen et al. 2008; Xin et al. 2013). This system could provide exciting data, from which to test a range of hypotheses relating to invasive species ecology. As will continue to be highlighted, the greatest paucity of research and knowledge gaps related to introduce mangroves appears to be exploring ecological and social impacts in SSI habitats.

\section{Additional Knowledge Gaps in Mangrove Ecosystems:}

Future research which clarifies the reasons behind differential colonization rates of nonnative mangroves in various habitats may provide critical information in understanding the potential for mangroves to become highly invasive/spread rapidly in some geographic regions but not in others. For example, ESI mangroves in Hawaii (Allen, 1998) colonized much more rapidly than on the island of Rodrigues in the Indian Ocean (Perry and Berkeley, 2009). Differences in rates of spread for multiple species of SSI planted in the China (Li et al. 2011) and Florida (Fourqurean et al. 2010) case studies mentioned earlier provide valuable natural experimental settings to help ecologist unravel the importance of various ecological hypotheses about propagule pressure, genetic bottlenecks, and the "lag-time" many invasive species undergo before rapid range expansion, to name a few (Sax et. al. 2005). These are exciting avenues for future research; yet their depth extends beyond the scope of this project. Therefore, focus is directed towards highlighting ways to collect data in ways which also tests more basic science tenants of invasive species ecology.

\section{MANGROVE ECOSYSTEM SERVICES IN NATIVE and NON-NATIVE (ESI and SSI) HABITATS}

\section{PROVISIONING SERVICES:}

Native mangrove forests enhance a wide range of provisioning ecosystem services by directly supplying natural resources which humans utilize (including wood for construction, fuel, medicinal, and ornamental resources such as flowers to local communities), and indirectly by helping to provide critical habitats and nursery grounds for a wide range of fishery species 
(Everard et al. 2014). Provisioned resources vary temporally and spatially (from season to season and place to place), with exploitation of different ecosystem services often linked to harvest times, economic markets, local food security needs, as well as the availability of alternatives to mangrove wood (such as propane or electricity to meet heating and cooking needs) (McNally et al. 2011). To provide these services, mangroves have been introduced to many new regions, and subsequently encouraging specific shifts in local biodiversity and seasonal resource availability.

\section{Enhanced Coastal Fisheries:}

The enhancement of subsistence and commercial fisheries is often cited as one of the most important mangrove associated ecosystem services (Igulu et al. 2013). Providing nursery habitat for specific taxa, which are later harvested from adjacent habitats (e.g. nursery vs. adult habitat), is considered a supporting ecosystem service (MEA, 2005), however is discussed here with provisioning services as many of the same species are harvested directly from mangrove and adjacent systems (Primavera, 1998).

Research has shown that populations of specific Caribbean coral reef dwelling fish are significantly enhanced when living adjacent to mangrove covered shorelines (Figure 7). One example highlighted by conservation efforts includes the largest herbivorous fish in the Atlantic, the rainbow parrot fish (Scarus guacamaia) (Mumby et al. 2004). This species appears to have an obligatory mangrove association, and has suffered local extinction following the clearing of adjacent shoreline mangrove habitat. Blue-striped grunt (Haemulon sciurus) also increased in biomass by more than 25 times on patch reefs adjacent to mangrove covered shoreline in this same study. However, there is still much controversy regarding the role mangroves play as nursery habitats for a wide range of species and across different geographic regions (Nagelkerken et al. 2008; Bostrom et al. 2011; McMahon et al. 2012). In the Mumby et al. (2004) study, for example, of the more than 100,000 fish from 164 species, only S. guacamaia appeared to have an obligatory mangrove association.

Mangrove/fish associations also appear to be geographically variable. As mentioned, several species of reef fish in the Caribbean appear to extensively utilize mangrove habitat, while mangroves in the Indo-Pacific region "are hardly used as a habitat by reef fish;" the seagrass beds appear to satisfy the role as nursery/protective habitat instead of shoreward mangle (Dorenbosch et al. 2005). This difference provides a specific example of a knowledge gap in native mangrove systems which is outside the scope of this paper, but is interesting enough to deserve mention and further scientific attention, and advances in tracing habitat use through otolith (fish ear bone) isotopic ratio chemistry are starting to unravel some of these uncertainties (Kimirei et al. 2013). 

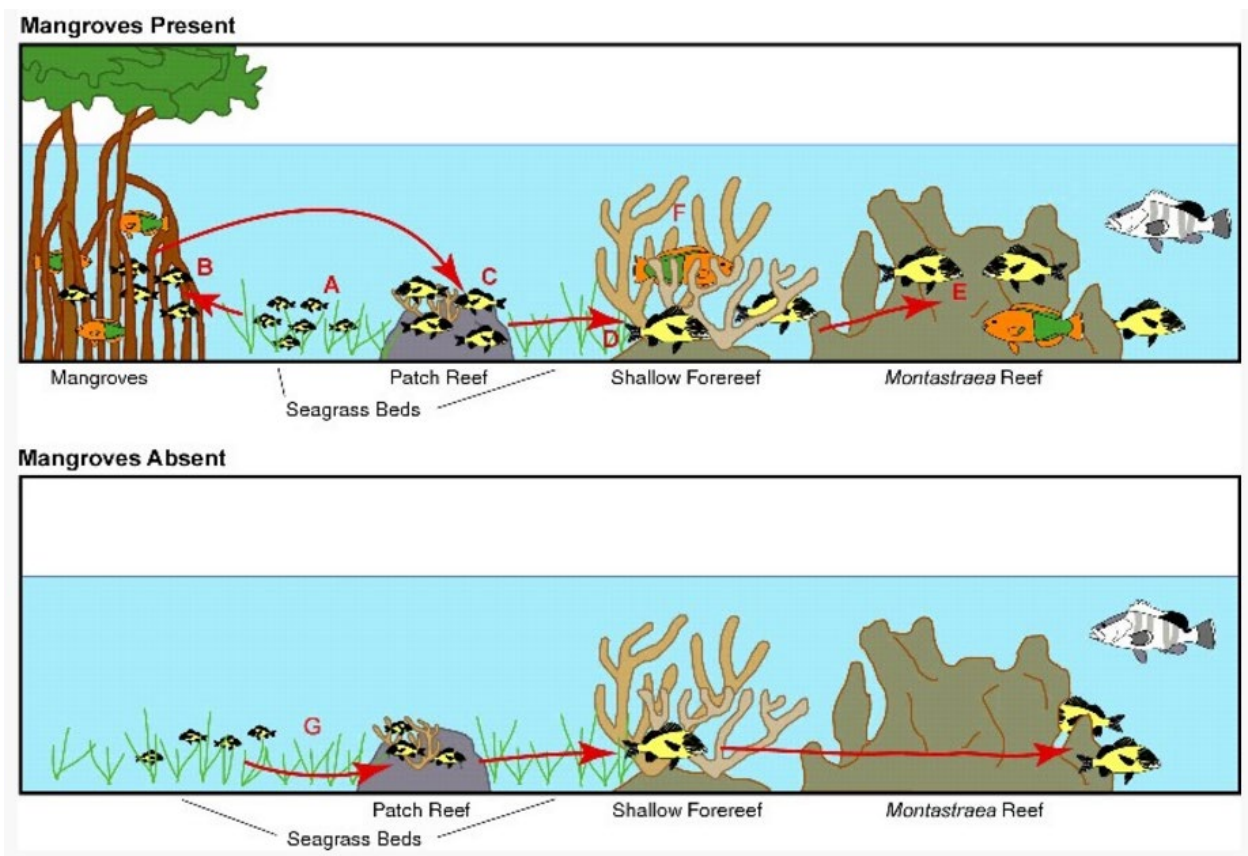

Figure 7: Standard Model of how mangroves enhance coastal fisheries (MarineSpacialEcologyLab.org).

Not only do specific fish in certain locations show various levels of obligatory relationships to the mangle, different species of mangrove also appear to enhance specific provisioned resources. For example, species of mangrove with pneumatophore pencil-roots were shown to harbor higher densities of fish than species with prop-roots, while the converse was true for economically important shrimp and prawn taxa (Ronnback et al. 1999). This is partially because during flood tides, fish are able to forage above pencil roots, while prop-root species maintain structural complexity throughout the water column. Nonetheless, mangrove/fish associations are extremely important to local communities, as one study from the Philippines demonstrated that approximately $97 \%$ of harvested fish and shrimp species utilize coastal mangroves (Ronnback et al. 1999). Ronnback also explored how mangrove research in places like Pakistan on the Arabian Sea indicate larger fish and vertebrates prefer more open lower-intertidal Avicennia pencil-root habitat, while smaller juvenile fish and invertebrates utilize the denser mid-intertidal prop-root habitat of Rhizophora genera (IUCN, 2005).

\section{Other Provisioning Services:}

In addition to supporting coastal fisheries, mangroves themselves provide many direct ecosystem services to coastal communities. Rhizophora, for example, produce dense tannin-rich wood which burns very hot for a long time. This makes it an excellent choice for charcoal production (McNally et al. 2011). Harvested mangrove wood is also ideal for coastal construction due to its strength as well as being resistant to rotting and attack by wood boring pests such as termites (Walters et al. 2008). However, due to the relatively small diameter, mangrove wood is typically only suitable for fence posts and roofing for example (Conchedda $e t$ al. 2011). Tannins from mangrove bark have also been traditionally used for making a range of useful compounds ranging from dyes for coloring fabrics to fish poisons. Medicinal compounds extracted from mangroves are used to treat a variety of ailments around the globe ranging from high blood pressure to AIDS (Everard et al. 2014; Walters et al. 2008). As traditional ecological knowledge (TEK) from local inhabitants is allowed to guide many post-colonial research and 
natural resource management plans, huge strides can be made in building regional social capital as communities become increasingly engaged in mangrove conservation.

Provisioning Service Knowledge Gaps and Mangrove Introduction Uncertainties:

Despite documented benefits provided by native mangroves, introduced mangroves may have a wide range of effects on provisioning ecosystem services in new geographic ranges. Uncertainties exist regarding the role of non-native mangroves play in bolstering local fishery productivity, as well as the utility of resources directly provided by mangroves in novel habitats (where currently occurring taxa already fill local natural resource needs).

Exotic mangroves introduced as ESI into new locations may or may not enhance coastal fisheries as they do in their native ranges. MacKenzie and Kryss (2013) concluded, [assumed] prior to retained sediments completely filling tide pools converting them to terrestrial habitat, that, with regards to Florida red mangroves ( $R$. mangle) in Hawaii "Our data suggests that exotic mangroves in Hawaii are not having an adverse effect on native fish assemblages in tide pools, and may actually provide nursery habitat for native and exotic fish (MacKenzie and Kryss, 2013)." This may indicate that native species are able to change their behavior or ecological associations to capitalize on the novel environments created by expanding mangle, barring mangroves do not completely overgrow such habitats leading to competitive exclusion of all current intertidal taxa. Current and future studies by the Department of Aquatic Resources and various academic and community based scientists at locations like the Wai Opae tide pools may test hypotheses presented herein on the potential for Niche Evolution by fish and intertidal species. Contrarily, data showing native taxa utilizing exotic mangroves may merely demonstrate fishes' innate desire to utilize cover (i.e. native species exploiting new cover along impacted/deforested coastlines). Therefore, further research into mangrove-fish interactions is needed to clarify if native taxa prefer, not just tolerate, ESI mangrove habitats (Figure 8).
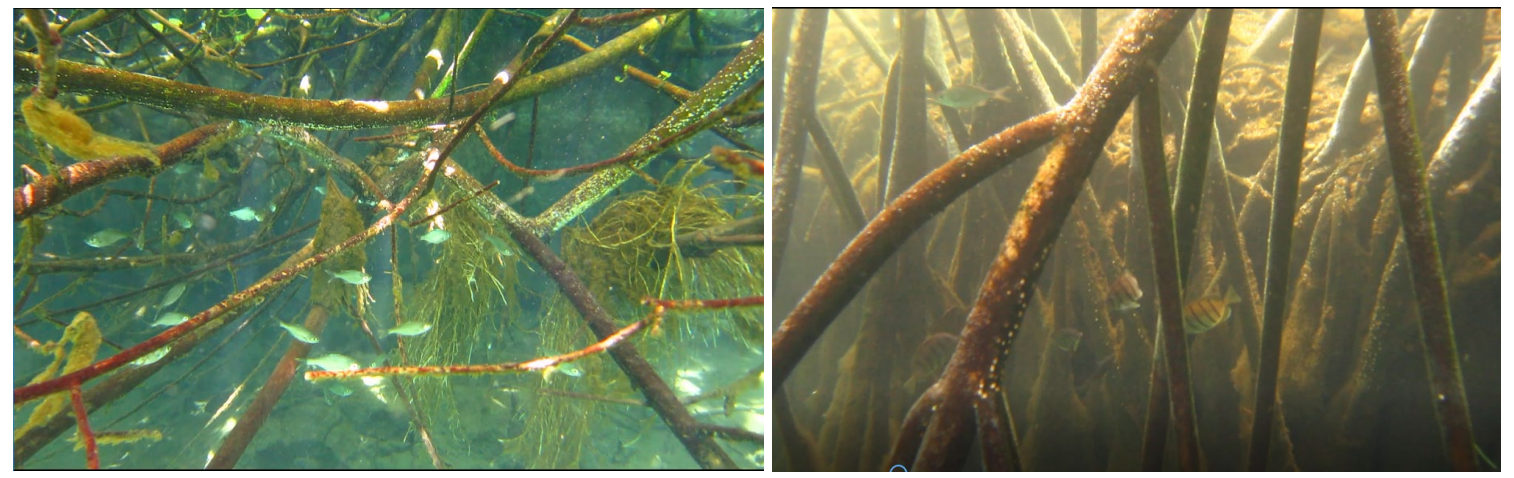

Figure 8: Native Hawaiian flagtails (Kuhlia sandvicensis) and convict tang (Acanthurus triastegus) under overhanging branches of coastal hau, Hibiscus tiliaceus, trees (left) and Florida red mangrove, Rhizophora mangle, prop roots (right) at comparable study sites near Hilo, Hawaii (Photos; Harwood and Deemer, 2012).

Few studies have investigated the utilization of newly provisioned ecosystem services from introduced mangroves, however, some studies indicate a possible increase in the abundance and diversity of other non-native, yet exploitatively valuable species such as Samoan crabs (Scylla serrata) and various mollusk (Nakahara, 2007; Demopoulos et al. 2007) in newly developing mangrove related niches. If future research correlates an increase in these species with introduced mangrove habitats, this would support the theory of non-native Facilitation (Bruno, 
2003), and a potentially exciting link between increased provisioning services and ESI mangrove establishment.

Mangrove Provisioning Services in the Republic of the Marshall Islands:

There is evidence that crabs, including coconut crabs (Birgus latro) harvested from the native mangrove forests on Namdrik Atoll (Figure 9) in the RMI have been a substantial food provisioning habitat of cultural significance (and legend) to local communities for centuries (Ellison, 2007). Therefore, successful mangrove introductions in the RMI are also expected to increase provisioning ecosystem services.

Facilitation of mangrove associates is not ubiquitous, however, and potential ecosystem shifts should be monitored closely to ensure benefits outweigh potential consequences prior to any mangrove introductions. Mangroves introduced as substrate for oyster aquaculture in Moorea, for example, continue to thrive although the expected mollusk fishery collapsed leaving behind the successfully expanding mangle (Langer and Lipps, 2006). Future research investigating introduced mangroves' role in supporting coastal fisheries is clearly necessary to inform management in the Pacific, as both broad geographic and local ecological conditions dramatically influence the success rate of trajectories of mangrove introductions.

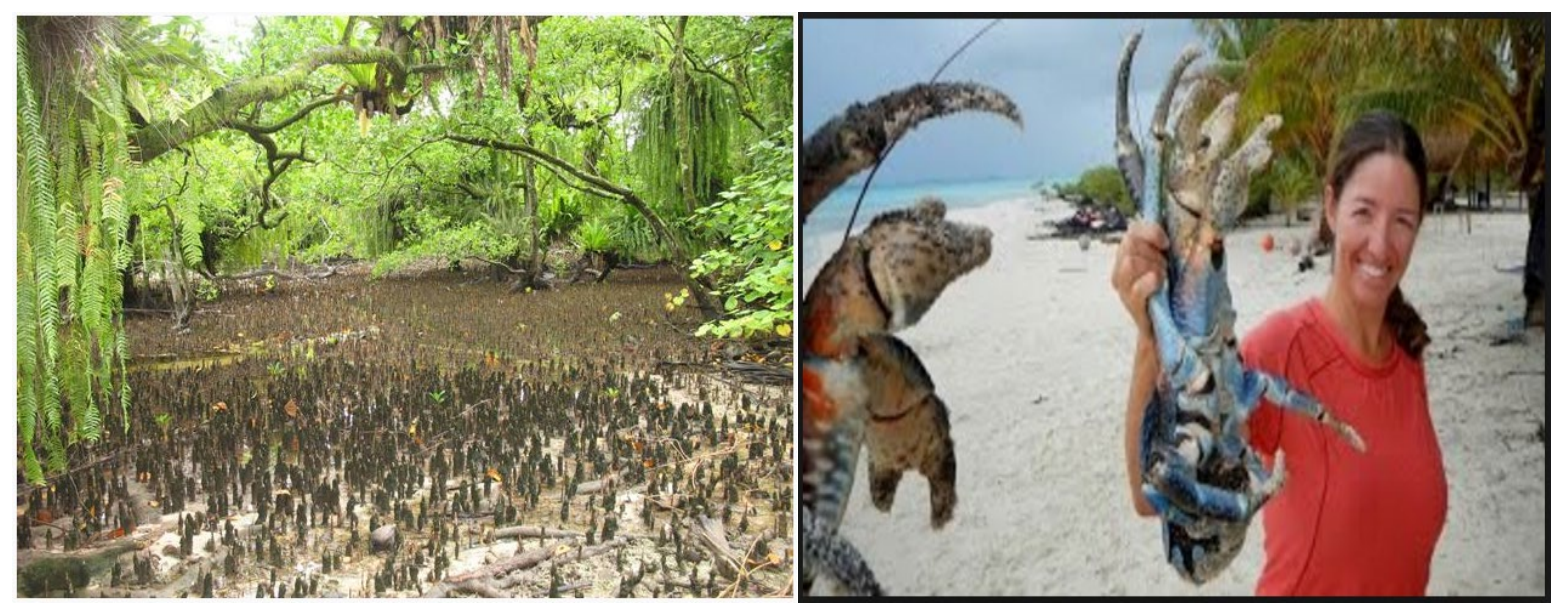

Figure 9: The Ramsar Mangrove Wetland on Namdrik Atoll, the largest mangle in the RMI, and a photo of the coconut crabs traditionally harvested from the area (Ramsar, 2012; D. and K. Kane, 2012).

Very little scientific research has been conducted to determine the effects of mangroves on provisioning services in SSI systems, such as in the RMI. There are five native mangroves in the RMI, introductions of which would likely provide similar nursery and predator avoidance benefits as on the currently inhabited atolls. More information on each of these species can be found in the Recommendations Section and appendices below. Natural movement of mangrove taxa among islands, via floating propagule seedpods, are expected to roughly follow the standard models outlined by Island Biogeography (MacArthur and Wilson, 1967); unfortunately, there is little available data which currently supports or refutes this for mangrove trees. In the RMI, Xylocapus rumphii/moluccensis mangroves may be a good candidate for testing these type basic science hypotheses, as all current trees in the RMI are thought to be descendants from a single parent tree (whose exact phylogeny may need to be confirmed through future molecular testing).

Several introduced tree species have a long history of importance to local communities in the Pacific, and humans quickly utilize the ecosystem services new species provide. No introduced tree species in the Pacific is more familiar than the coconut palm tree. Twenty three 
native Pritchardia spp. (Chapin et al. 2004), and the non-native coconut palm (Cocos nucifera), introduced by early Polynesian settlers, have been used for house construction, food, handicrafts, and medicines for centuries throughout the Pacific. Native species, such as Acacia koa trees in Hawaii and French Polynesia, have a long history of being used for canoe building, home construction, cloth and dye production, as well as a building material for furniture and instruments (Whitesell, 1984). Hau trees (Hibiscus tiliaceus), also introduced by early Polynesians to many Pacific islands are used to construct outriggers for canoes, as fuel wood, for medicinal remedies, and mangroves create aquatic structure that is utilized by shrimp and fish harvested at high tides (Santiago et al. 2000). With the wide range of native and non-native tree species in regions where mangroves have been introduced, they may provide few additional provisioning ecosystem service benefits over existing vegetation, yet enhance the specific services (such as sediment retention) they were introduced to provide.

The wide range of uses of the five native mangrove species in the RMI, ranging from providing construction and fuel wood to producing fungicidal coatings for nets and fish traps, illustrates how traditional ecological knowledge already exists in Marshallese culture of how to garner provisioning ecosystem service benefits from the native mangrove species.

Understanding how expanding the ranges of mangroves in the RMI will affect provisioning services requires additional research. As global trade increases over the next century, the number and speed of transportation vectors for newly arriving non-native species also increases. Additionally, future benefits from introduced species may become apparent. For example, there are no native species of termite in Hawaii; however eight species have been anthropogenically introduced over the past centuries (Woodrow et al. 1999). The importance of termite resistant mangrove wood (McNally et al. 2011) as a new construction material may become increasingly important as newly invading pests colonize and spread. This example illustrates the dynamic nature of ecosystem service provisioning, and underscores the difficulties in constructing "future scenarios" which predict the full suite of shifts in net ecosystem service provisioning following species introductions.

\section{REGULATING SERVICES:}

Mangroves provide a wide range of regulating ecosystem services throughout their native ranges. Some of the most notable include: shoreline protection from extreme weather and geologic events like tsunamis through wave attenuation (breaking up wave energy), the regulation of atmospheric gases through carbon sequestration, bioremediation and breakdown of toxic pollutants, and mangroves have been shown to remove excess nutrients from coastal systems through biological incorporation fertilizing new vegetative growth.

\section{Coastal Protection:}

One of the most often cited regulating services that mangroves provide is shoreline protection through breaking up incoming wave energy (attenuation) and providing erosion control (reviewed in Everard et al. 2014). Semi-aquatic trunks and exposed roots of mangroves dissipate energy from incoming waves, and of the tsunami in the Indian Ocean in December of 2004 (Figure 10), destroyed many structures along unvegetated shorelines, while those inland from the protection of coastal mangrove forests suffered significantly less damage (Danielsen et al. 2005). The regulating ecosystem service of coastal protection by mangroves was again evident in 2006 after Cyclone Larry made landfall in Queensland, Australia; economic and 
structural damage was much lower in areas inland from mangrove habitat (Bell and Lovelock, 2013). Many mangrove restoration efforts are designed to enhance this natural protective barrier for coastal communities.
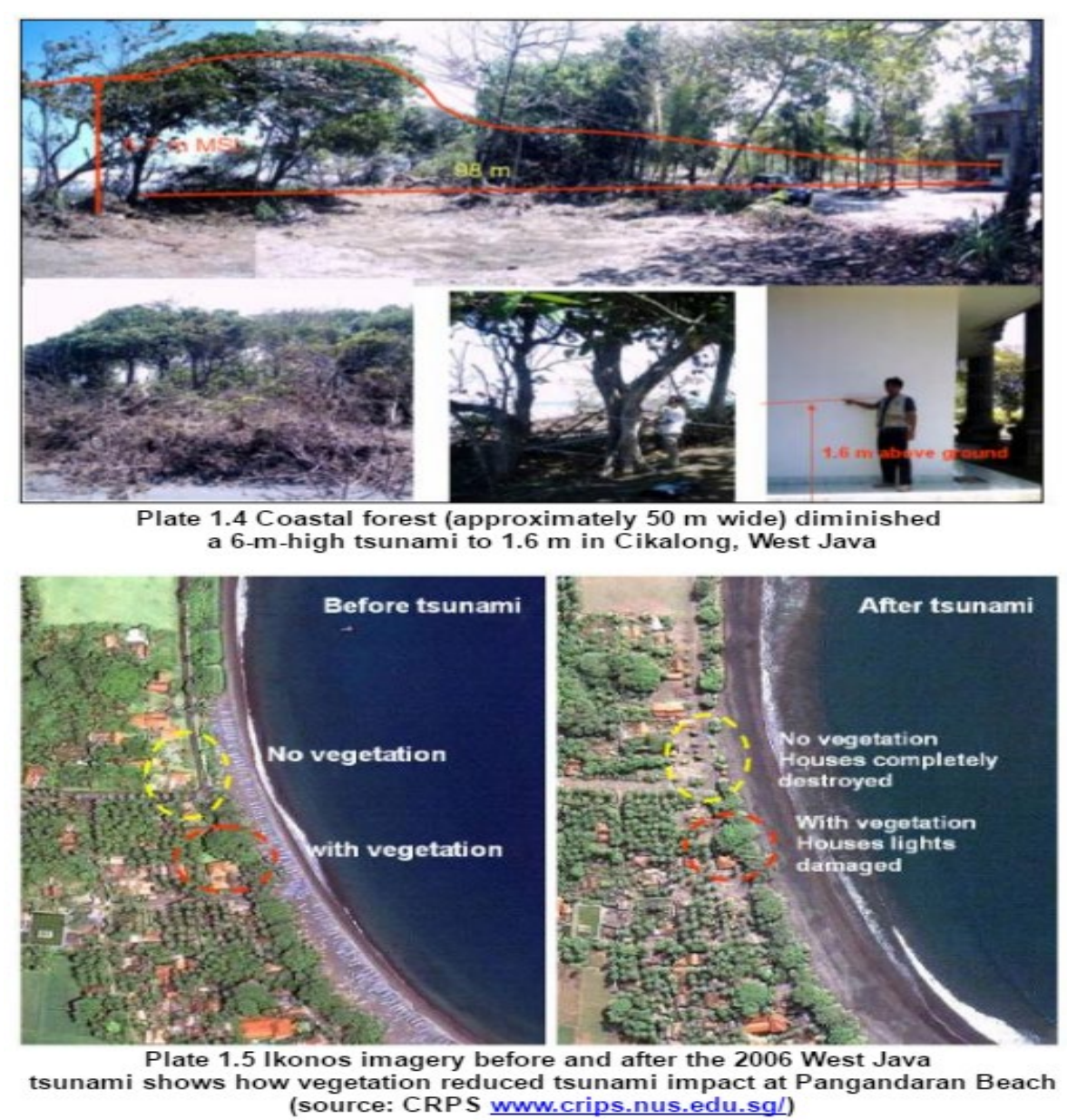

Figure 10: Shows an example of mangroves wave attenuation abilities, providing a valuable regulating ecosystem service to coastal communities (FAO.org).

The non-linear relationship between the size of mangrove patches and rapid wave attenuation that occurs at the seaward edge of the mangle indicates that even small mangrove stands may provide substantial coastal protection (Koch et al. 2009). As a general rule of thumb, wave attenuation occurs at a rate of $1 \%$ of the wave's energy being dissipated per meter of shoreward forest, meaning total attenuation normally occurs within the first $100 \mathrm{~m}$ of the seaward edge of coastal vegetation. However, due to the non-linear nature of attenuation, $>60 \%$ of wave energy is dissipated within the first 20 meters of dense mangle (Gedan et al. 2011). This highlights the importance of even small buffer zones of mangroves for coastal communities at risk from oceanic climate change threats, such as the Marshallese on low-laying Pacific atolls. Coastal protection is such an important regulating ecosystem service provided by mangroves that some people have made the case that residential insurance companies should provide funding for mangrove rehabilitation efforts following extreme weather events which damage mangrove forests which protect shoreline property (Bell and Lovelock, 2013). 
Atmospheric Regulation:

Mangroves also help regulate the amount of atmospheric carbon and sequester carbon dioxide from the air very efficiently as they grow, making them among the most carbon rich ecosystems in the tropics. Their extremely high carbon sequestration rates, of roughly $25.5 \mathrm{MT} \mathrm{C}$ $\mathrm{yr}^{-1}$, provide over $10 \%$ of the organic carbon to the world's oceans, despite their narrow and highly specialized halophilic semi-aquatic shoreline niche (Polidoro et al. 2010). Intact mangrove stands in the Dominican Republic, for example, have been shown to store over five times the amount of carbon compared with the same land area cleared of mangroves and converted to aquaculture shrimp ponds (Kauffman et al. 2014). Ominously, using the IPCC stock-change approach, predictions indicate that mangrove ecosystems also have the potential to release more $\mathrm{CO}_{2}$ than other tropical forest ecosystems following land conversion as carbon stored in mangrove sediments is liberated (Kauffman et al. 2014). This indicates that native mangrove forest removal for coastal development may have a range of unintended ecological consequences as released carbon and nutrients could exacerbate local greenhouse gas emissions (Donato et al. 2011).

The predominant storage of carbon in mangrove ecosystems occurs in the sediments rather than carbon being stored in the biomass of living plant tissues (McLeod et al. 2011). Although new growth through photosynthesis sequesters a substantial amount of carbon from the atmosphere into aboveground biomass, belowground carbon storage (soil layering) can account for between 46 and $99 \%$ of carbon storage in mangrove forests (Kauffman et al. 2011; Jones et al. 2014). Unlike inland tropical forest soils, which may hold carbon from decaying organic matter for only decades before it is reused by the ecosystem, mangrove sediments in Belize for example have been shown to store carbon for more than 6,000 years and accumulate carbon rich layers $>10 \mathrm{~m}$ thick (McLeod et al. 2011).

Therefore, mangrove habitats may provide a valuable new market programs which provide payments for ecosystem services (PES), such as the United Nations Reducing Emissions for Deforestation and Forest Degradation (UN-REDD+) which promote carbon sequestration in vegetation and natural ecosystems to off-set global industrial carbon emissions (Lau, 2013; Escobedo et al. 2010). Even though mangroves account for $<1 \%$ of the total land area of tropical forests, mangrove deforestation is occurring at $1-2 \%$ per year globally. This accounts for almost $10 \%$ of global carbon emissions from tropical forest systems (Kauffman et al. 2014). Therefore, incorporation of mangrove forests into REDD+ type programs could provide economic support for mangrove conservation and restoration efforts in rural communities or island nations which help off-set increasing global $\mathrm{CO}_{2}$ emissions. Exotic Species Introductions can also lead to the release of stored carbon. On Oahu, Hawaii, for example, soil organic carbon levels were still significantly elevated even 6 years after ESI mangrove removal (Sweetman et al. 2010).

Bioremediation of Toxic Pollutants and Excess Nutrients:

Other important regulating services provided by mangroves in their native ranges include the bioremediation of toxic pollutants (breaking them down to less harmful/more useable forms) and the ability of mangroves to remove excess nutrients from urbanizing coastal watersheds through metabolic processes as they grow. Nutrient pollution, normally in the forms of high levels of nitrogen and phosphorus from sources such as fertilizers and seaport industries, may cause phytoplankton blooms whose subsequent breakdown and decay (by oxygen consuming bacteria) causes anoxic 'dead-zones' when oxygen concentrations in the water column drop below the tolerance level of many fish and marine species. Mangroves may help off-set these 
impacts in coastal ecosystems through both uptake and/or burial of these nutrients before they can reach off-shore waters. In areas with limited waste treatment facilities, such as the in Small Islands Developing States in the Pacific, this is an extremely valuable service (especially in areas where tourist waste increases the demands on local provisioning and regulating services). Mangroves exposed to higher nutrient levels in wastewater outflow also showed a significant increase in microbial abundance within biofilms, again indicating mangle's value in processing human waste (Yang et al. 2008; Bouchez et al. 2013).

Sediments in native mangrove forests harbor bacteria which not only help consume nutrients and biological waste, some bacteria also break down industrial compounds which are toxic to humans (Figure 11), including case studies where mixed polycyclic aromatic hydrocarbon (PAH) concentrations in fluorine were reduced by $90 \%$, phenothrene by $80 \%$, flouanthene by $70 \%$, pyrene by $68 \%$, and benzopyrene by $32 \%$ (Santos et al. 2011). Some of these bacteria also degrade 'spilled' crude oil under low oxygen and anoxic conditions (Li et al. 2009). This is a particularly important finding, as PAH tend to accumulate in higher concentrations in organic rich anoxic mangrove sediments with high proportions of clay-sized particles compared to adjacent marine sediments where aerobic degradation may occur more quickly (Li et al. 2009). These results indicate that indigenous microorganisms in native mangrove sediments are capable of alleviating substantial amounts of coastal contamination as a valuable regulating ecosystem service.

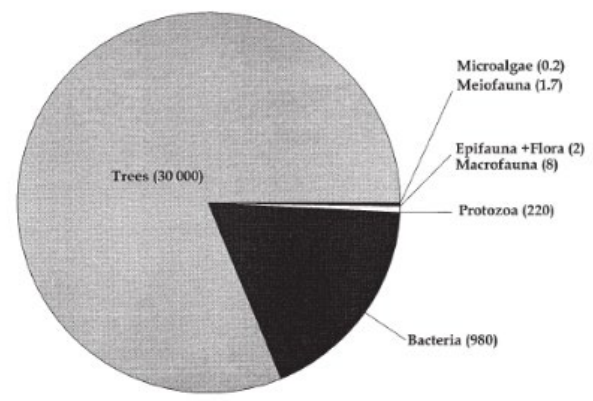

Figure 11: The distribution of living biomass $\left(\mathrm{g} / \mathrm{m}^{3}\right)$ in a mixed Rhizophora forest in northern Australia. Note mangrove associated bacteria account for roughly $75 \%$ of non-tree biomass in native mangle (Alongi, 2002).

Nutrient uptake in concert by mangroves, biofilms, and associated bacteria are instrumental in reducing eutrophication in coastal ecosystems. Mangrove trees themselves have the capacity to tolerate and utilize high levels of ammonium (Krauss et al. 2008), which increases their ecosystem service value adjacent to coastal aquaculture systems, such as shrimp farms on Molokai in Hawaii or pearl oyster aquaculture in the lagoon of Namdrik Atoll in the RMI for examples. Walters et al. (2008) estimated that 22 ha of mangroves would be able to process the nutrient load generated by one hectare of intensive commercial shrimp farming, while Primavera (2008) demonstrated that 1.8-5.4 ha of mangroves would be able to remove the nitrates generated by a 1 ha shrimp pond. When co-managed, mangroves and small-scale substance aquaculture can support each other with the aquaculture supplying nutrients for mangroves to thrive, while the mangrove remove toxic ammonium and provide habitat for juvenile seed or adult brood stock for local aquaculture species.

Regulating Service Knowledge Gaps and Mangrove Introduction Uncertainties:

Coastal protection is likely the most economically valuable ecosystem service provided by introduced mangroves; however data supporting their role in attenuating wave energy in new 
locations, sediment retention (for better or worse), and the ecological effects from clearing mangroves deemed "invasive" all require further research. Non-native mangroves may provide sustainable and cost effective regulating services which provide protection against newly emerging threats posed by global climate change, and increases in regulating ecosystem services might be much greater in ESI habitats than SSI habitats where shoreline protection is already provided by native mangrove species. This is somewhat contradictory to other ecosystem service categories, which may see greater declines in services following introductions into ESI habitats (i.e. exclusion of native biota, restricted human beach access, etc.), yet regulating services are hypothesized to be of the greatest positive ecosystem service gains in ESI habitats.

Carbon sequestration demonstrates the potential net enhancements of regulating ecosystem services provided by ESI mangroves in particular. An ecosystem's ability to sequester aboveground carbon is largely determined by plant growth rates rather than the total biomass of standing stocks. Rapid range expansion of ESI mangroves over open habitat exponentially increases the abundance of younger age classes and aboveground biomass, maximizing the rate of carbon sequestration in a newly developing mangle (Livesley and Andrusiak, 2011). SSI mangrove planting in Zhanjuang, southeast China, show a striking difference here, with limited impacts detected following new mangrove species establishment within native mangrove forests. For example, non-native $S$. apetala mangroves did not show a difference in standing biomass or soil carbon pools over native stands alone post-introduction (Lu et al. 2014). This indicates that introduced mangroves may not significantly enhance carbon storage in SSI habitats, with possible implications for REDD+ type PES programs as well.

Although total acreage of mangrove forests is declining globally due to coastal development and aquaculture, natural range expansion of many mangrove species is actually predicted from many climate change models as the temperatures in non-tropical latitudes increases (MEA, 2005). Further research is needed to determine if mangrove soils in more temperate regions store substantially less carbon than in native tropical systems, as is suspected (Livesley and Andrusiak, 2011). This again highlights the importance of accounting for the interplay of both biotic and abiotic factors when constructing post-colonization mangrove scenarios regarding shifts in suites of ecosystem services following introductions.

The ability of mangroves to provide bioremediation of toxic pollutants in non-native systems is also poorly understood. Future research would clarify how ecosystem services along urbanizing coastlines may be enhanced following mangle development. Poly-aromatic hydrocarbons, for example, may break down more slowly in ESI systems lacking co-evolved microbial communities found in native mangrove sediments, for example. As adjacent off-shore habitats are under increased pressures from coastal eutrophication and contaminate loading from terrestrial watersheds mangroves may act a filter, and provide resilience to adjacent off-shore marine habitats such as coral reefs. Mangroves on Oahu, for example, show roughly two times greater growth rates in urban settings than in rural settings (Fry and Cormier, 2011) further indicating their bioremediation value along urbanizing coastlines. The capacity of mangroves to tolerate and utilize high levels of ammonium (Krauss et al. 2008) shows their value in more rural coastal aquaculture systems which often suffer from chronic nutrient over-enrichment (Keala et al. 2007).

Contradictory scientific theories may provide testable hypotheses for investigating shifts in regulating services following mangrove introductions. Under Niche Evolution based scenarios, greater positive gains in services are expected than under Niche Conservatism scenarios, especially if bacteria at introduction sites (which account for more than $80 \%$ of the total living 
biomass in native mangrove soils) and other native macrofauna adapt to capitalize on new mangrove derived nutrients (Genthner et al. 2013). However, tannins produced by mangroves inhibit digestive enzymes of many detritivores (Demopoulos and Smith, 2010), and taxa that have not co-evolved with mangroves may be excluded. Niche Conservatism suggests lower nutrient cycling rates in regions of exotic species introductions.

Mangrove Regulating Services in the Republic of the Marshal Islands:

Despite these uncertainties, small island nations such as the RMI may see the greatest increases in new ecosystem services coming from the Regulating Services category. Mangrove's ability to provide coastal protection from rising sea leaves, extreme weather events, and tsunami waves make mangrove introductions along suitable coastlines in the RMI a viable natural buffer option (over expensive and more impactful seawall construction for example (Figure 12). Additionally, on small islands, where waste treatment facilities are limited, mangles have served as areas of waste disposal for local communities. Mangroves introduced to other outer atolls in the RMI may also serve as 'natural waste disposal sites,' further enhancing regulating service gains post-colonization.

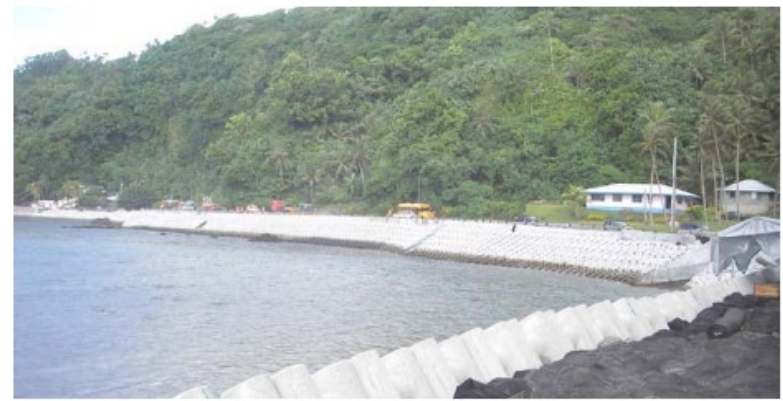

Fig. 21. Erosion control structures such as this seawall in American Samoa can effectively protect coastal infrastructure and development, but are expensive to maintain, and often lead to the conversion of the existing coastal ecosystem into deepwater habitat (photo by E. Gilman).

Figure 12: A constructed seawall, built to dissipate incoming wave energy in American Samoa (Gilman et al. 2006).

\section{SUPPORTING SERVICES:}

Native mangrove forests support extremely high biological diversities of marine and terrestrial taxa of various life stages which, in turn, fulfill a multitude of ecological roles themselves. Mangrove trees themselves take in and use autochthonous nutrients ('normal' levels of nutrients from within the ecosystem), and return nutrients which support adjacent ecosystems through decay. These critical services are accomplished through an interweaving of various components, much like how a heart and lungs work in unison to deliver oxygen through our blood to our organs, supporting services gain value from the interworking's of healthy ecosystem components to consistently provide a stable environment which can deliver end goods and services that increase human health and well-being through supporting ecosystem services. 


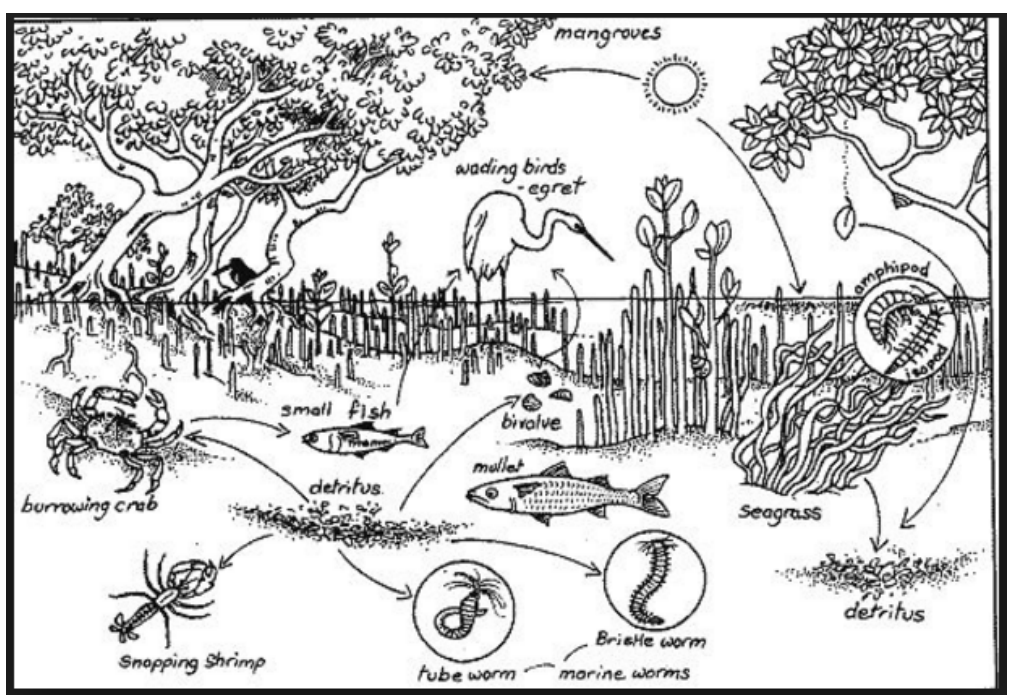

Figure 13: Artist depiction of the biodiversity of mangrove ecosystems in Aceh, Indonesia (Rafie, 2014).

Biodiversity:

Creating healthy habitats and protecting local biodiversity are two of the most important supporting ecosystem services that native mangles provide. Mangrove forest biodiversity studies (reviewed in Nagelkerken et al. 2008) report an astonishing range of taxa (Figure 13) from global case studies: up to 80 sponges representing 10 species per square meter of mangrove coastline in Cuba, 32 species of copepod (zooplankton) in study plots in India, 94 species of nematode worms in Brazil, 39 species of gastropod mollusk in Australian mangroves and 23 species of mollusk in mangrove forests in Hong Kong, 16 species of grapsid crabs from Columbia, 102 species of herbivorous insects in Singapore, more than 85 species of elasmobranch (including sharks and rays) have been identified in estuary systems where mangroves are common, at least 600 fish species have been identified in mangrove systems in the Indo-West Pacific region, many of the 23 extant species of crocodilians rely on mangrove habitats for all or part of their life-cycle, 18 species of snake were report from mangroves in south-eastern Nigeria, mangroves in Australia have been shown to host 186 bird species, and a wide diversity of mammals ranging from tigers, primates, buffalo and bats to dolphins and manatees in the terrestrial and marine realms utilize mangrove habitats. Although most of these species are not mangrove obligates, the plethora of different life forms associated with mangroves indicates the value of these habitats for global biodiversity conservation and the range of supporting services associated with protecting each of these niche filling species.

\section{Nutrient Cycling and Other Supporting Services:}

There are many other documented supporting services provided by mangle. Herbivorous fish supported by mangroves, for example, make coral reefs more resilient to regime shifts from coral to algal dominated systems (Mumby et al. 2004). Another interesting example documents how burrowing organisms in mangrove sediments aerate anoxic sediments, detoxify hydrogen and metal sulfides on burrow walls, and increase biologically available nutrients and bacteria densities which provide resources and food larger food web communities (Lenihana and Micheli in Bertness et al. 2001). These processes promote benthic-pelagic coupling and nutrient cycling within the mangle and between mangrove and adjacent systems. 
The supporting service of soil formation within and adjacent to mangle is often a dynamic shift following introduced mangrove establishment. As discussed in relation to regulating services and carbon sequestration, the nutrient rich "soil" layer of organic matter accumulates from leaves and other decay beneath the mangle. On the molecular level, phytochemicals including flavolans, tannins, combined with the low nutritional value of mangrove material (high $\mathrm{C}: \mathrm{N}$ ratios) may actually deter the ingestion and subsequent decay of mangrove litterfall into biologically available forms (Hogarth, 2007). This leads to organic rich, anoxic soils which change the fundamental structure of the benthic marine communities from burrowing organisms to surface deposit and filter feeders, as shown in both SSI studies in China (Leung and Tam, 2013) and ESI systems in Hawaii (Demopoulos and Smith, 2010).

Supporting Service Knowledge Gaps and Mangrove Introduction Uncertainties:

Shifts in supporting services are not always immediately apparent, often being overshadowed by declines in provisioning or regulating services which are more readily identifiable as problematic. Shifts in local supporting services may reveal broad underlying processes affecting larger geographic regions, such as the example of a transition from an aerated sandy benthos to finer grained clay sediments deprived of oxygen. Interestingly to note however, following mangrove colonization, several studies have shown that non-native mangrove ecosystems may harbor higher overall biodiversity than native coastal habitat types, particularly under ESI scenarios. To elaborate, this increase in biodiversity following non-native mangrove establishment may be similar to the Intermediate Disturbance Hypothesis (IDH) which states that the highest level of biodiversity will be found when there are moderate (but not lacking or extremely severe) levels of habitat disturbance in the system (Sousa, 1979). Mangroves colonizing narrow strips of coastline may fall into this category of moderate coastal disturbance when discussed in within the IDH framework. For example, sediment macrofaunal communities in non-native mangrove forests on Oahu and Moloka'i showed higher species abundance and richness compared to adjacent native sand flats at equivalent tidal elevations (Demopoulos and Smith, 2010; Nakahara, 2007; Siple and Donahue, 2013), meaning more new taxa appeared than were excluded from the shifting habitat. This finding may support niche evolution, and highlights uncertainties relating to how introduced species may bolster or suppress local marine biodiversity.

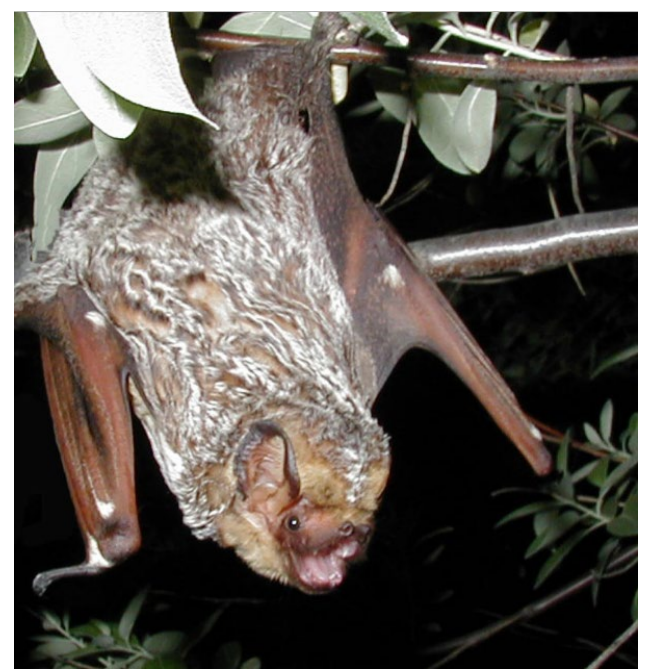

Figure 14: The only native mammal in Hawaii, the Hawaiian hoary bat, may utilize mangroves or mangrove supported insects help this unique endangered species survive (Cryan, USGS.gov). 
Biodiversity may also be supported in a number of ways on the inland/terrestrial boundary of the mangle. Within ESI Florida red mangroves, Hawaii's only native mammal, the Hawaiian hoary bat (Figure 14), and the native Hawaiian black-crown night herons have been found roosting in mangroves following deforestation of native species (Duffy et al. 2007; Rauzon and Drigot, 2001). In contrast to these benefits, non-native mangroves in Hawaii have been shown to negatively impact 4 endangered shorebird species, where they have overgrown tidal flats used for foraging and nesting (Allen, 1998). This may indicate Niche Conservatism is more prevalent for native terrestrial species than marine taxa, a hypothesis that requires future research.

Furthermore, ESI mangroves also harbor high densities of non-native terrestrial species including cattle egrets (Bubulcus ibis), the Indian mongoose (Herpestes edwardsii), and large orb spiders (Argipoe appensas); indicating non-native facilitation in prevalent in terrestrial habitats as well. Despite the empirical evidence that most ecosystems are not saturated with species and new arrivals rarely displace current inhabitants (Sax et al. 2005; Lockwood et al. 2007), endemic or local biological and genetic diversity have the potential to decline following non-native species introduction. In some cases hybridization between introduced and native species, can lead to genetic extinction and the loss of locally adapted traits (Harwood and Phillips, 2011). Hybridization between native and introduced mangrove species is already evident in the Pacific, as is clearly shown in Appendix 3, wherein a map of known mangrove hybridization events in the Pacific is shown (Gilman et al. 2006).

Species which are co-adapted to utilize native mangrove habitat will likely be able to capitalize on SSI mangroves post-introduction, so little change is expected in regional biological diversity. Furthermore, a study examining the abundance of 34 invasive species in two bays in South China documented only intermittent SSI mangrove colonization (Sonneratia apetala) within the native Chinese mangrove forests (Figure 6; Ren et al. 2009). When viewed in line with the discussed scientific theories, this may provide support for niche conservatism for plants in SSI environments and resistance to substantial ecological shifts which displace native taxa. In Malaysia, however, Leung and Tam (2013) point out that introduced Sonneratia caseolaris mangroves behave "intrusively rather than neighborly" in disturbed systems, where it outcompetes the dominant native Nypa fruticans trees, and becomes increasingly resistant to human disturbance leading to $S$. caseolaris becoming dominant. The authors also indicate that this SSI mangrove has a tendency to become more dominant in new habitats vs. in S. caseolris's native range.

In exotic introduction systems, many of the co-evolved biological associations present in native mangle appear to be lacking in ESI habitats (Allen, 1998). As previously mentioned, the paucity of mangrove predators and fungal associates (Enemy Release Hypothesis) in ESI systems indicates the likelihood of decreased cycling of mangrove derived nutrients in accumulating deadfall (Steele et al. 1999; Volmann-Kohlmeyer and Kohlmeyer, 1993). Significant reductions in benthic food web complexity and utilization of mangrove derived nutrients in an ESI system over a native mangrove system is therefore expected due to detritivores in non-native systems being poorly adapted to utilize the tannin-rich and nitrogen-poor mangrove detritus (Demopoulos et al. 2007), aligning with Niche Conservatism hypotheses. Introduced mangrove systems provide an opportunity for future research to directly study Niche Evolution vs. Conservatism as well as investigate potential differences in the rates that nutrients cycle in their new non-native systems. In particular, examining microbial food webs and nutrient cycling in ESI systems may provide a window into processes which are observable at the timescale of scientific research. 
Nutrient cycling in Similar Species Introduction systems, contrarily, is likely to be much higher than in Exotic Species Introduction systems since co-evolved detritivores are able to tolerate the high levels of tannins in introduced mangrove leaf tissue. In SSI introduction sites, native microbes may be better suited to breakdown mangrove litter fall than in ESI habitats, so species specific growth rates and exact nutrient ratios becomes more important in SSI systems with similar native competitors. Lu et al. (2014) showed that carbon cycling is expected to increase where $S$. apetala is planted (SSI) due to this non-native mangrove species' higher litterfall and lower carbon/nitrogen ratios in its leaves, making it more palatable than native mangrove species present. Adaptive management plans that mandate decadal monitoring is recommended to identify these scale shifts in supporting ecosystem service.

Mangrove Supporting Services in the Republic of the Marshal Islands:

Studies indicate that there may actually be increases in biological diversity, with no species extinctions of RMI flora or fauna following mangrove introductions. The small pockets of available habitat which could support introduced mangroves localize any negative shifts to supporting services to the area of mangrove establishment. Enhanced supporting services on atolls without current mangle in the RMI is expected, and native microbial communities in the region are already co-adapted to utilize mangrove litter-fall. Colonization of mangrove associates is expected to naturally occur following introductions in the RMI. Hydrologic demands, including freshwater requirements, should be considered per-species on atolls where freshwater resources require allocation. Transpiration of freshwater from soils and aquifers may become problematic on small atolls already suffering from saltwater intrusion.

\section{CULTURAL SERVICES:}

Mangroves provide a multitude of cultural services to local communities include immeasurable spiritual and customary benefits. There are also more quantifiable values such as recreation and ecotourism dollars spent visiting natural parks containing mangrove ecosystems, educational opportunities for local and global visitors, a plethora of scientific research avenues, and mangrove ecosystems also serve as community focal points for environmental conservation efforts which engage local citizens and enhance social capital throughout the region.
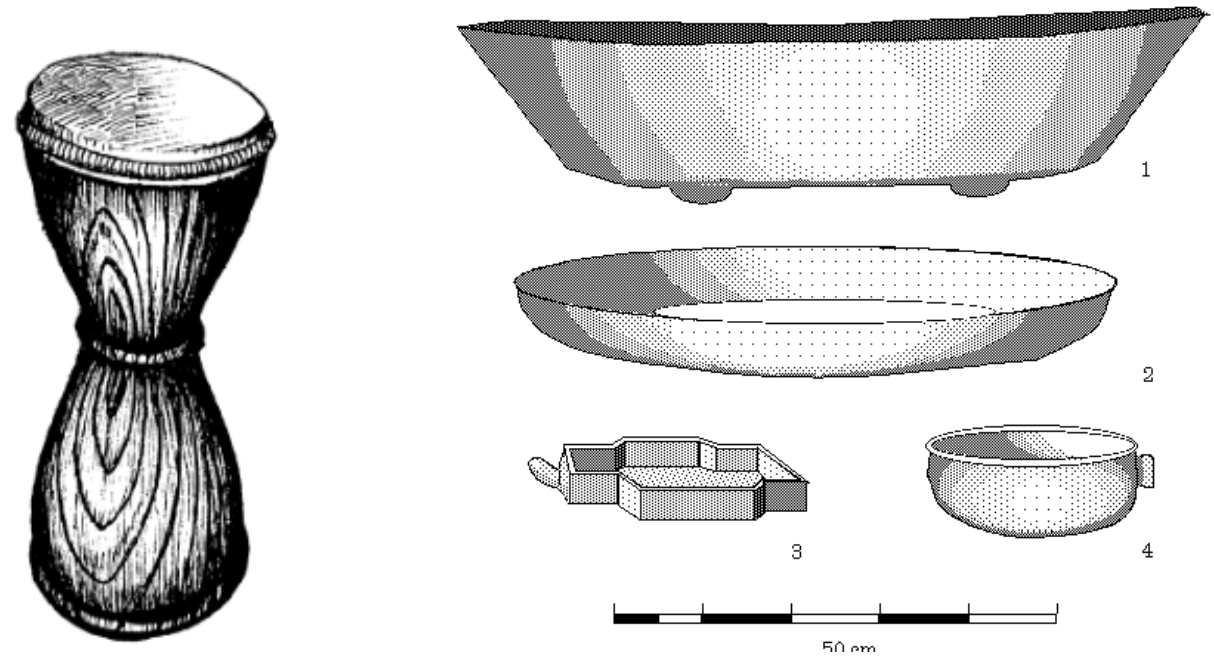

Figure 15: Depictions of a traditional Marshallese aje (waist) drum made from kone or jon mangrove wood with a shark stomach drum head (left) and traditional Marshallese serving bowls (right) (Spennemann, 1998; Kramer, MIstories.org). 
Spiritual Benefits:

The spiritual importance of mangroves in native systems is well documented. In Java, Indonesia, for example, mangroves still hold a valued place in local spirituality. Legends tell of how their creator carved the first humans out of a mangrove root, which sprang to life when this God played a drum created from a mangrove tree; mystic totems are still routinely carved in Java from mangrove wood to this day (Walters et al. 2008). In the Solomon Islands, mangroves are routinely used for kastom art, such as creating wood carvings and spears for traditional welcome dances (Warren-Rhodes et al. 2011). Mangroves' central role in local spirituality in their native Pacific range is well documented (Figure 16). As modern history unfolds, mangroves continue to hold a prominent place in human lives, including non-native locations along the southern coast of Molokai, for example. Mangroves may also be affecting local Hawaiian spirituality, as ancestral fishponds become overgrown by invasive Florida red mangroves, and historic sites of religious food provisioning are lost.

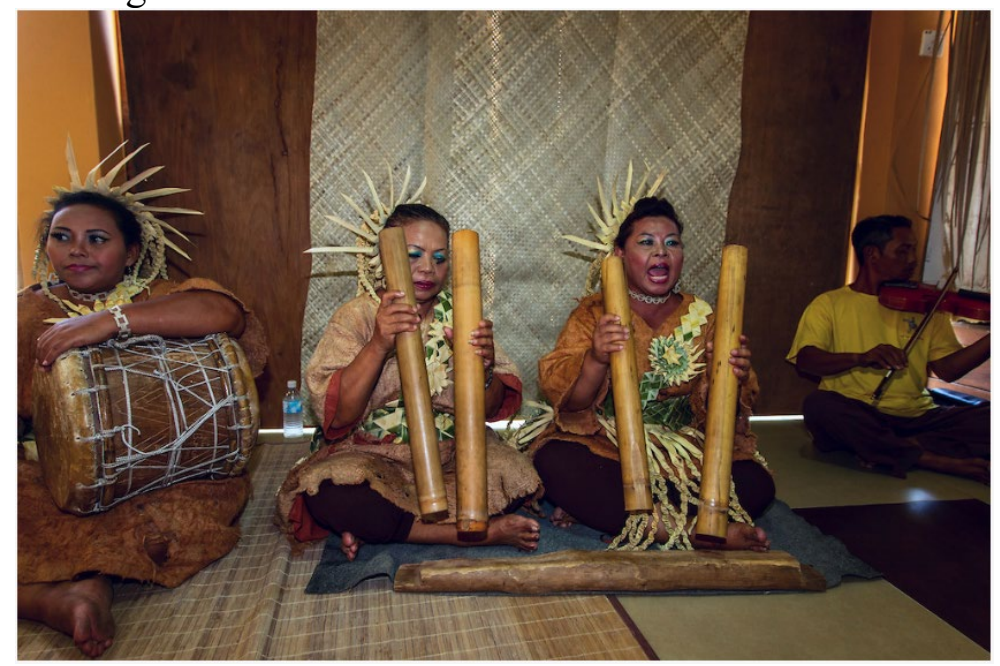

Figure 16: Mah Meri people of western Peninsular Malaysia playing traditional instruments made from red mangrove wood (Photo: Ahmad Yusni).

\section{Recreation and Ecotourism:}

Mangroves also provide cultural benefits in the form of recreation and ecotourism, bringing substantial income to local communities. The mangrove forests and associated biodiversity in the Hara Biosphere Reserve in Iran, for example, make this region the most significant ecotourism destination in the country (Dehghani et al. 2010; UNESCO.org) Other studies have shown the recreational value of mangrove forests along the Red Sea in Egypt (FAO.org) may approach \$20 per individual visit (Hergazy et al. 2002). Many natural resource managers at natural parks, such as Tanbi Wetland National Park in Gambia, West Africa, are constructing boardwalks through mangrove forests to provide ecotourist access to see how the Avicennia africana, Alder Conocarpus, Laguncularia racemosa, Annona glabra and Rhizophora each play their role in these unique ecosystems (Satyanarayana et al. 2012; ACCESSGAMBIA.com). Future studies in locations like these can efficiently correlate changes in regional tourism to the creation of new ecotourism and recreation opportunities associated with mangrove forest conservation. This could ultimately provide much needed income to help strengthen communities through linked conservation and ecotourism projects (SPREP.org). 


\section{Education Opportunities:}

In addition to their spiritual and recreational value, mangrove ecosystems also have substantial educational value for local school children to learn about local environments which strengthens their sense-of-place (Figure 17). Students, residents, visitors, and many eager young scientific researchers excited about slogging through the mud are needed to collect the data to test some of the ecological hypotheses presented and illuminate some of the knowledge gaps associated with these unique plant species. The roughly 15,000 annual visitors to the mangroves in Muthurajawela Wetland in Sri Lanka, for example, are primarily on educational or research trips, and three quarters of them take a boat trip into the marsh area to learn about the mangrove ecosystem (Emerton and Kekulandala, 2003; IUCN.org). The Biosphere 2 project highlighted the importance of mangroves in its $441 \mathrm{~m}^{2}$ mangrove mesocosm and paired natural field plots in southwestern Florida (Finn, 1996). Natural mangrove systems also serve as an environmental education platform for local communities regarding sustainable natural resource provisioning, such as training areas for how to harvest of post-larval tiger prawns for aquaculture seed-stock in the Sundarbans of India (Sarkar and Bhattacharya, 2003; WWF.PANDA.org ).
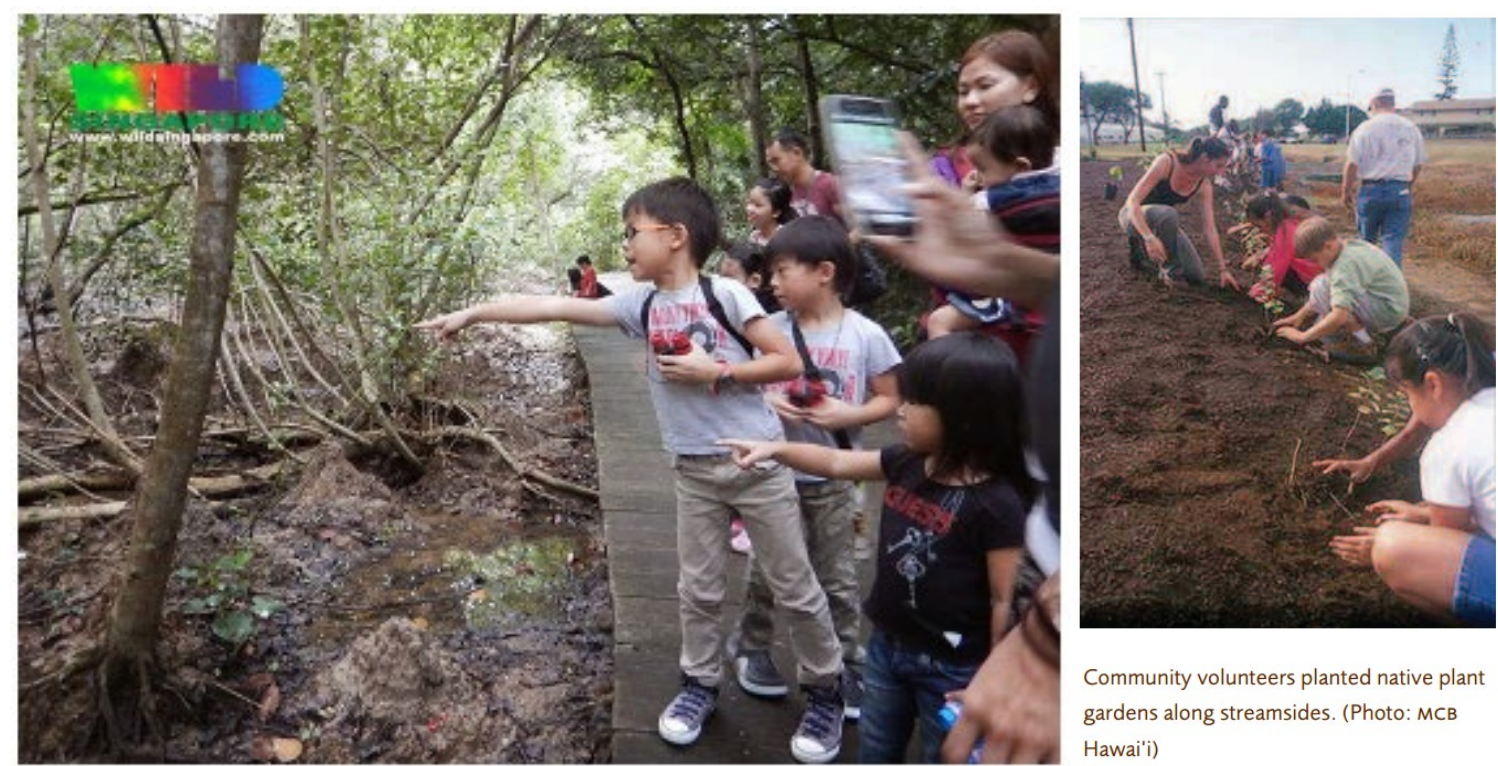

Figure 17: Community engagement and education in a mangle near Singapore, and social capital building on Oahu's Marine Corp Base Hawaii (Benton et al. 2008) while replanting native species following ESI non-native mangrove removal.

\section{Building Social Capital:}

Walters et al. (2008) and Satyanarayana et al. (2012) provide comprehensive reviews of many ethnobotanical and cultural uses of mangroves and demonstrate how incorporating traditional ecological knowledge (TEK) is vital to the development of sustainable natural resource management plans. They show how valuing TEK increases social capital by empowering and engaging community stakeholders in a framework which allows them to share their personal knowledge and stories about local mangroves to assist in creating regional management plans. Economic benefits may also follow, as successful alternative livelihood projects promoting mangrove conservation have tended to occur in communities with strong local leadership and social cohesion (O'Garra, 2012). Non-political environmental restoration 
projects may promote collaborations which enhance the social capital (meaning the people, resources, and political environment required for successful collaborations and project goal achievements) in a region (Vilardy et al. 2011).

Cultural Service Knowledge Gaps and Mangrove Introduction Uncertainties:

Mangrove introductions may lead to unintentional shifts in local cultural ecosystem services. Understanding the range of impacts from exotic species introductions requires particular attention. One of the most often cited disservices of ESI mangroves to local communities is the overgrowth of historical sites of great spiritual and cultural significance, including native Polynesian fishponds and archeological sites on several Hawaiian Islands (Farber, 1997; Fronda et al. 2008). As ESI mangroves establish on walls and stone structures, mangrove roots expand in small cracks, breaking apart the very foundations of many religious sites along the coast (requiring substantial labor and financial investment to restore). Furthermore, there may be little cultural tolerance for mangroves viewed as "invasive species," as positive historic relationships have not been built to off-set perceived negative impacts in ESI systems (Figure 18).

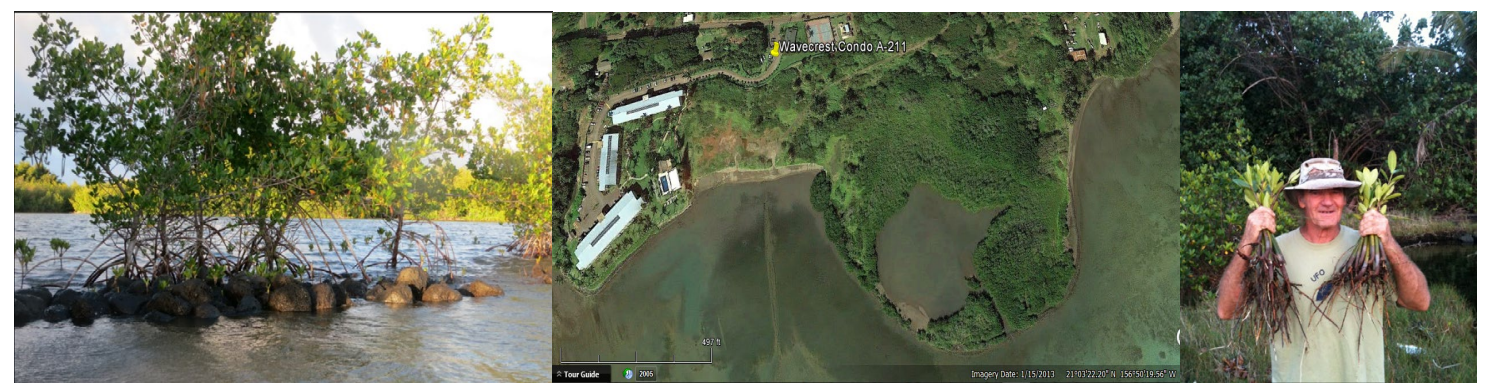

Figure 18: $R$. mangle overgrowth of the Puh'hoa ancestoral fishpond walls leading to complete habitat conversion and exclusion of marine taxa on Molokai milepost 13 (Photos: Harwood, 2012; GoogleEarth), and hand removal of ESI mangrove propagules at Onekahakaha fishpond on Hawaii Island (Photo: Sunday-Grover, 2012).

Local communities in SSI environments, on the other hand, often have previously developed cultural practices that value native mangrove species. Therefore, it is less likely for SSI mangroves to have negative impacts on local spirituality and customs. This is in stark contrast to ESI mangroves deteriorating culturally important structures along Hawaiian coastlines, and an example of how future research is needed to explore location specific differences.

Furthermore, introduced mangroves may reduce recreational opportunities in ESI habitat types, and to a lesser extent in SSI habitats, as they overgrow historically valued beaches and open coastlines. In Hawaii for example, locals often avoid once popular areas where mangroves have now established because of the noxious odors and increased abundance of mosquitos (Per. Comm. at Onekahakaha, 2012). However, since the same introduced species can be valued/utilized by different communities in different ways, it is difficult to predict the full range of potential ecosystem service shifts. Locals on Hawaii Island may view mangroves in a negative light because of the disservices mentioned above, many locals on Moloka'i appreciate the seclusion mangroves provide (Per. Comm. w/ Kaunakakai residents, 2012). Conversely, where mangroves are SSI, they may have a neutral or positive affect on visitation to a region. For example, ecotourism opportunities to places such as the Dongzhai Harbor Mangrove Nature Reserve, China, annually host thousands of visitors from around the globe (Xin et al. 2013; UNESCO.org). Mangrove reforestation projects in these areas add biological diversity to pre- 
existing mangrove forests, recolonize disturbed areas, but also enhance local's "sense of place" and help educate future generations about the benefits of native mangrove forests. These sharp contrasts between shifting cultural ecosystem services in ESI and SSI (and even within ESI) habitats emphasizes the need for future research regarding the cultural ecosystem service shifts related to mangrove introductions.

Non-native mangroves have both positive and negative effects on social capital, an important cultural ecosystem service, as mangrove introductions build cohesion or dissention within a community. On Hawaii Island, for example, mangrove eradication efforts bring together natural resource and invasive species managers, yet their efforts have caused schisms affecting social relationships where herbicidal treatments are met with resistance from local residents (Kobsa, 2010). However, fishpond restoration and mechanical mangrove removal projects on the islands of Molokai and Oahu help to create social cohesion and reconnect locals with traditional aquaculture practices (Ka Honua Momona, personal communication; Garrison et al. 2002). Interestingly to note, many locals on the island of Molokai also appreciate the fact that ESI mangroves restrict shoreline access and limit beach habitat, accepting this restriction over corporate beach development which has occurred throughout much of Hawaii over the past century. Locals at One Ali'i Park adjacent to several historic fishponds on Moloka'i's southern coast clearly state mangroves as a major reason that large resort chains have not established on this island. Locals at the farmer's market in Kaunakakai, Misaki's and Friendly Market, and Atlas and Molokai Supply feel this helps maintain close community relationships, culture, and traditional lifestyles on the island (Per. Comm. w/ Kaunakakai residents, 2012).

Mangrove Cultural Services in the Republic of the Marshal Islands:

Mangrove wood has been used on the Marshall Islands for centuries to make handcrafts ranging from drums to tableware (Figure 15). Mangroves already have an important cultural role in the Marshall Islands. In such cases, introduced mangroves are likely to have minimal negative effect on social capital, though conflicts may arise between stakeholder groups attempting to restore historic habitats with native species and resource managers attempting to reforest cleared areas with faster growing non-native species (Xin et al. 2013). These conflicts, however, may lead to increased region social capital as stakeholders work together to solve common problems. In the RMI, where disperse communities often rely on common goals to bring together families over large geographic distances throughout the island chains, mangrove introduction efforts may provide a concrete focal point for connecting diverse Marshallese communities in a pro-active effort to combat climate change threats on their individual islands/atolls.

\section{CONCLUSIONS:}

The wide range of geologic and hydrologic conditions in geographically diverse mangrove ecosystems has made ecological comparisons and generalizations difficult (Krauss et al. 2008). However, with increasing intentional introductions, unintentional transport, spread from establishment sites, and natural range expansions, a better understanding of the ecological consequences and shifts in ecosystem services relating to non-native mangrove establishment is critical.

To explore near-future shifts in ecosystem service provisioning, the thematic comparison between Similar Species Introductions vs. Exotic Species Introductions of mangroves was utilized as a qualifier for habitat type. Additionally, to garner an understanding of potential distant-future shifts in ecosystem service provisioning, the theories of Niche Conservatism vs. 
Niche Evolution were used to construct various scenarios regarding the shifts in mangrove ecosystem service provisioning (in the four MEA categories) in ESI vs. SSI habitats. Predictions are based on two distinct possible responses from native biota to mangrove introduction, a known ecosystem engineer (Jones et al. 1994). If native species are able to adapt to changing conditions, and successfully utilize new mangrove resources, the theory of Niche Evolution was referenced to predict fewer negative and more positive net ecosystem service shifts following introductions. However, if native taxa are not able to adapt to rapidly changing ecological conditions, then Niche Conservatism predicts the exclusion of native taxa, and larger declines in net ecosystem service provisioning within all four ecosystem service categories.

Figure 19 below summarizes the theoretical shifts in these four main ecosystem service categories under ESI and SSI conditions, and under scenarios of Niche Conservatism vs. Niche Evolution (NC/NE), as discussed above. The weight (thickness) of the arrow indicates the predicted strength/magnitude of the net shifts in each ecosystem service category (synthesizing individual services provided in each category as discussed by section herein). Solid arrows represent increases in beneficial ecosystem services which they point to in the diagram, while dashed arrows represent declines the indicated ecosystem service category. Dashed arrows also attempt to encompass the promotion of disservices accompanying other positive services, such as foul odors released during bioremediation of coastal pollution.

These theoretical shifts are based on the previous scientific case studies discussed, yet require additional empirical evidence to test/support the research hypotheses predicted by each arrow in Figure 19. This provides a foundation for several distinct avenues of future research based on common vocabulary from established ecological theories to provide a thematic foundation for interdisciplinary collaborations. 


\section{STRENGTH AND DIRECTION OF ECOSYSTEM SERVICE SHIFTS FOLLOWING MANGROVE INTRODUCTIONS}

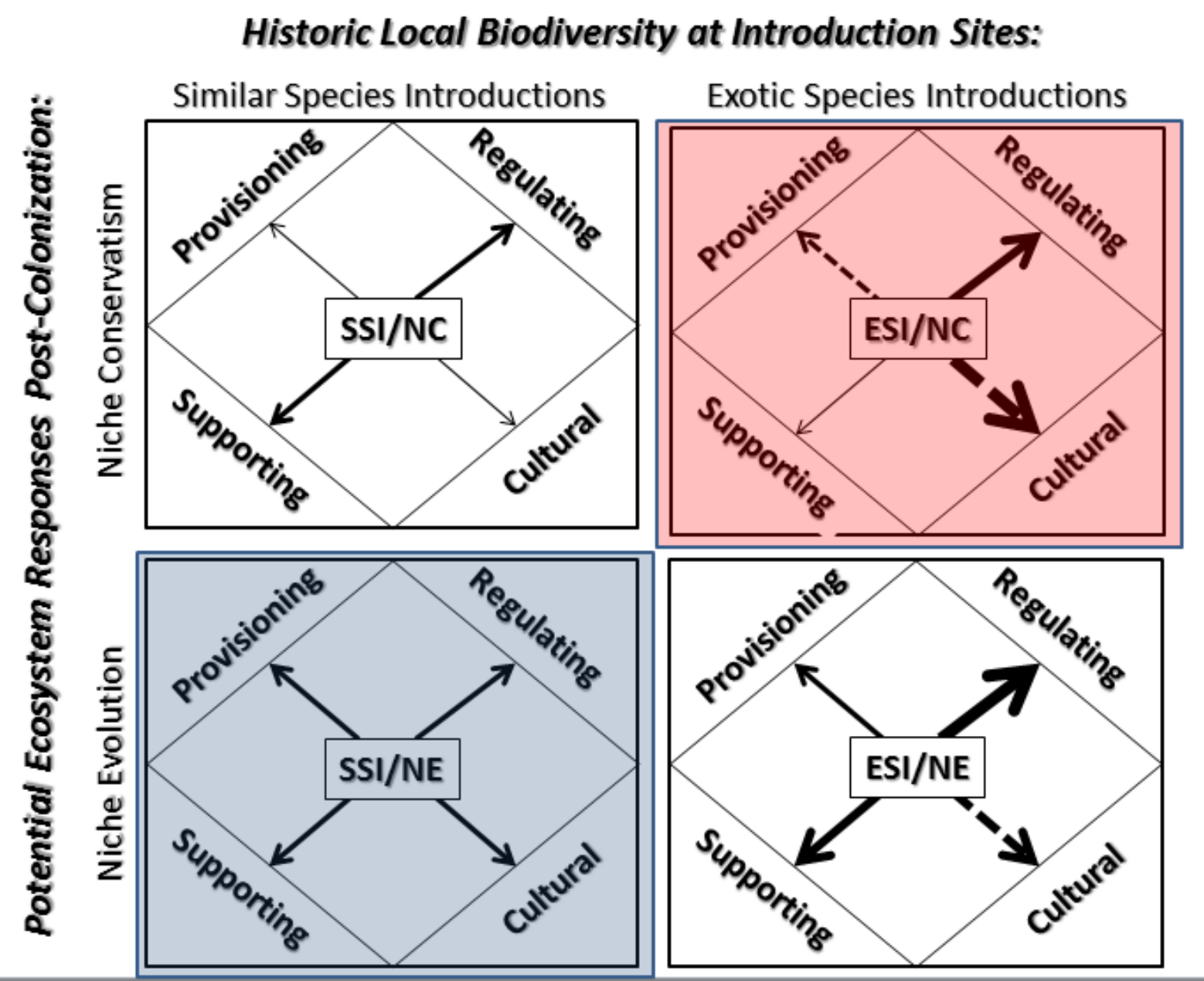

Figure 19: Diagram showing net theoretical shifts following mangrove introductions. Increases (solid arrows) and decreases (dashed arrows) in net shifts in ecosystem services for each category under four different ecological scenarios are provided: Similar Species Introductions (SSI scenarios) indicate native mangroves are historically present, while in Exotic Species Introduction (ESI) scenarios native mangrove species are historically absent. In niche conservation (NC) scenarios, native species are not able to adapt to novel conditions created by mangroves faster than their extinction rates, but in niche evolution (NE) scenarios native species undergo physiological or behavioral changes allowing them to capitalize on newly available mangle resources. The weight/thickness of the arrows indicates the theoretical strength (how much) of a change in ecosystem service provisioning. The red shaded box (upper right) shows the greatest potential deterioration in net ecosystem services, under ESI/NE conditions; the blue shaded box (lower left), conversely, shows a potential overall increase in all ecosystem service categories, under SSI/NE conditions.

The Marshall Islands fall into the left column of Figure 19 (Similar Species Introduction habitat), and therefore hypothesized to have net gains in all ecosystem service categories following mangrove introductions. This is expected to hold under either Niche Conservatism (NC) or Niche Evolution (NE) conditions. Ecological and human communities in SSI regions, such as the Marshall Islands, have likely co-evolved to capitalize on mangrove derived resources and habitats. Hence fewer negative shifts are predicted than under ESI conditions. Transitioning to utilize a new, yet similar, species of mangrove may not be very challenging for most native species under SSI scenarios. Additionally, under niche evolution scenarios ecosystem service 
provisioning is typically further enhanced due to native biological communities presumably adapting more quickly to capitalize on the newly engineered ecological niches by expanding mangles.

\section{SPECIFIC RECOMMENDATIONS FOR MANGROVE INTRODUCTIONS IN THE REPUBLIC OF THE MARSHALL ISLANDS:}

The introduction of any species of plant or animal by humans to a new location has environmental consequences. New ecological interactions may positively benefit coastal communities, or have unexpected and undesired effects on the ecosystem services which historically support local people. The effects of introduced species may be strong or weak, meaning their impacts are perceived to a greater or lesser extent, and positively or negatively affect ecosystem service provisioning, but shifts will almost certainly occur.

In the Republic of the Marshall Islands, the human-assisted range expansion of the currently present mangrove taxa to similar ecotypes (tidally vs. inland adapted) is supported by this author as a climate change adaptation strategy. This includes the preservation and expansion of current mangle, as well as mangrove forest establishment on currently mangrove-free islands and atolls using native Marshallese mangrove species. Low cost and sustainable climate change adaptation strategies are being sought throughout the region to help protect the world's most vulnerable populations to climate change threats. McIver et al. (2015; also McIver et al. 2015) sum up the expected human health impacts of climate change on Pacific Island nations, after their very extensive study, by saying:

"The highest priority climate-sensitive health risks in Pacific island countries include trauma from extreme weather events; heatrelated illnesses; compromised safety and security of water and food; vector-borne diseases; zoonosis; respiratory illnesses; psychosocial ill-health; non-communicable diseases; population pressures and health system deficiencies. Adaptation strategies relating to these climate change and health risks can be clustered according to categories common to many countries in the Pacific region."

Marshallese communities attempting to defend against such imminent threats are in need of a range of tools to help ensure that their communities and cultures will not just survive, but thrive in the coming decades. As an easily implementable short-term (decade-century temporal scales) strategy to increase shoreline resiliency in the Marshall Islands, it is concluded herein that only the five genera (historical species) of mangrove currently inhabiting the Marshall Islands be used during coastal protection efforts within the RMI (Ellison, 2007; Vander Velde and Vander Velde, 2005; Hawaii.edu). Over the past century, several species have been reported on various atolls but are not currently found inhabiting them. Other mangrove species, like Xylocapus spp., were likely introduced prehistorically, yet evidence points to a single parent tree on Jaluit Atoll (Figure 20) prompting the spread of this species in the RMI in particular (Vander Velde and Vander Velde, 2005). 


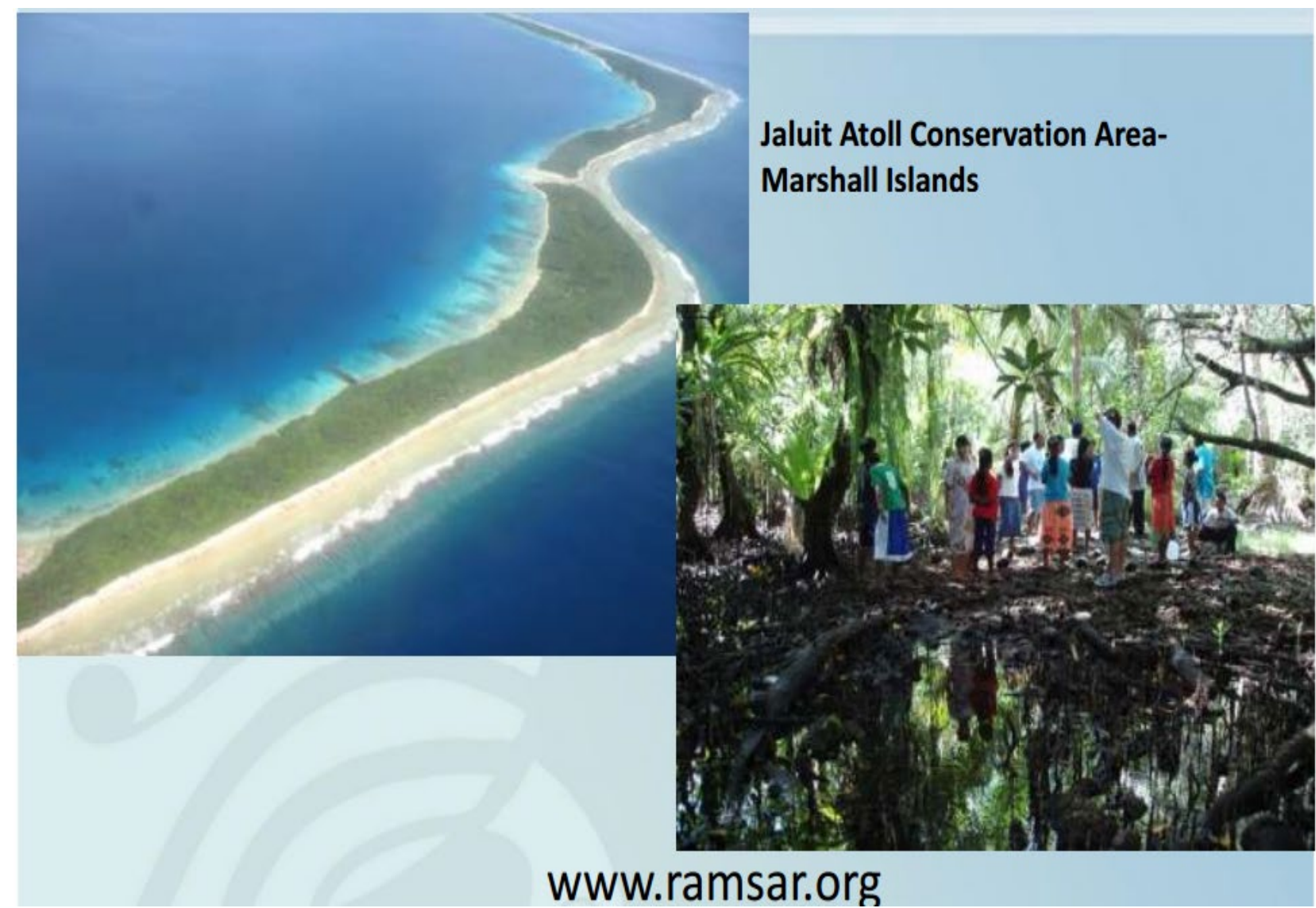

Figure 20: The landmass of a typical Marshallese atoll, and the Jaluit Atoll Conservation area $\sim$ centered in the landmass photo (Ramsar.org).

Final recommendations for site-specific introductions should be made following a formal local environmental assessment whenever possible, and the nearest geographic population of desired mangroves should be selected for transplant whenever possible. Since different mangrove species inhabit different coastal and inland habitats, adequate care should be taken in choosing which species to introduce at each specific location. Some mangrove species thrive in protected depressions away from the coastline, while others dominate more open ocean and exposed intertidal habitats. Individual mangrove species may also provide unique suites of ecosystem services, such as the Regulating Service of coastal protection from the open ocean by Rhizophora versus establishing inland mangles to enhance food security on outer atolls with Sonneratia or Bruguiera. The five main mangrove genera currently present in the RMI should sufficiently provide the full range of desired ecosystem service benefits. Some of the distinctive features of the RMI mangroves are shown in Figure 21. Again, it is recommended that the nearest populations of only specifically desired taxa should be selected for mangrove introductions whenever possible. 


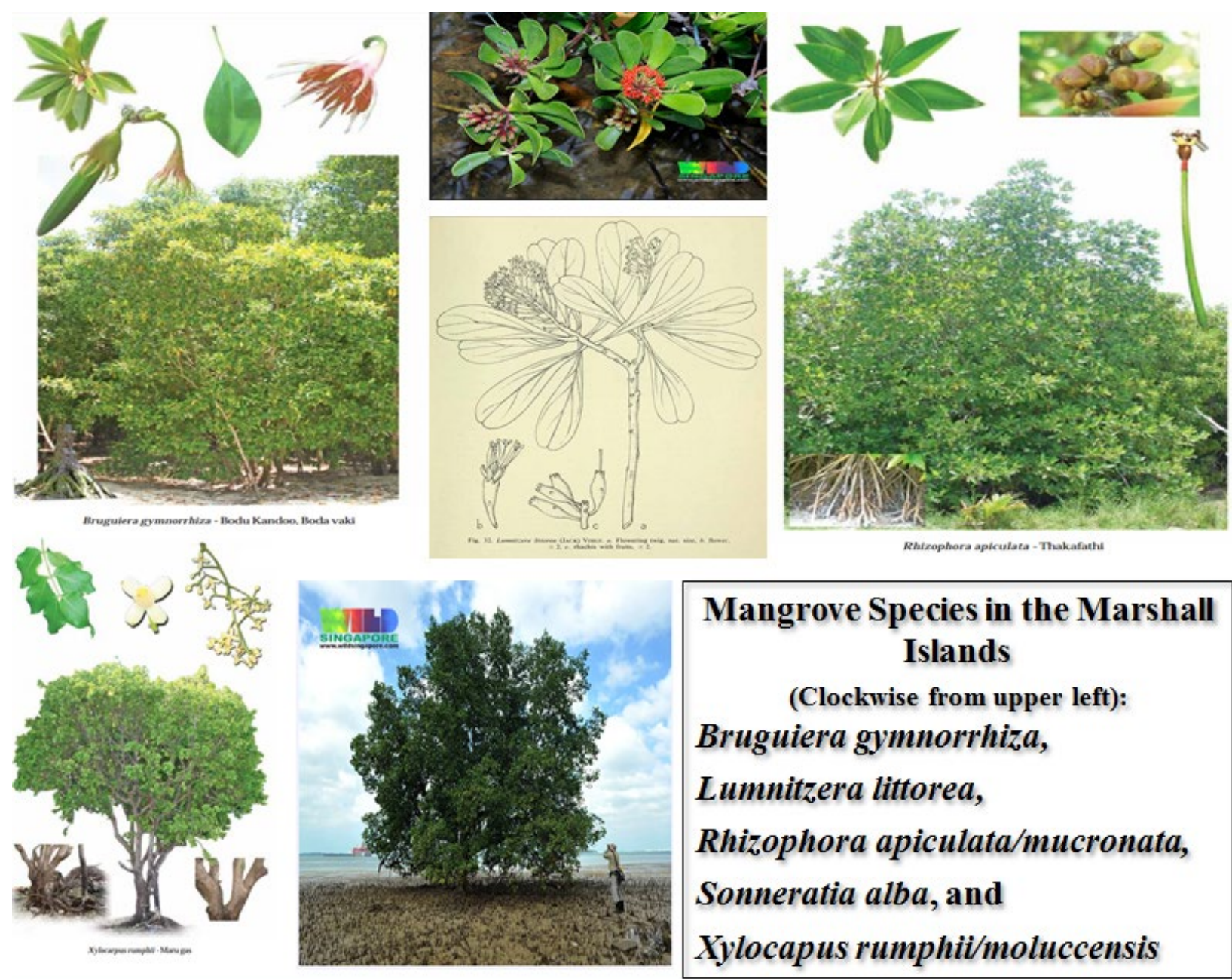

Figure 21: Illustrations showing common physiological features of the five mangrove genera found in the Marshall Islands (plantillustrations.org; fao.org; and swbiodiversity.org).

The five native genera (with genetic data still confirming some exact species distinctions) are each discussed from three reference frames of their: 1) native Marshallese habitat 2) historical uses and 3) projected impacts from the introduction of each genera to surrounding habitats and/or atolls in the Republic of the Marshall Islands specifically. Compatible taxa/site selections for various management strategies should be considered carefully, so the literature referenced below is presented and summarized with this objective. Please use recommendations as a guide to assist Pacific communities brace for increasingly severe climate change related events.

\section{Mangrove Species in the Marshall Islands and Potential Climate Change Buffering Capacities:}

Mangroves often follow a similar pattern of zonation of taxa from the intertidal zones towards more protected wetlands moving shoreward. If a mangrove species is introduced into an environment which does not meet that species niche requirement, introduction attempts often fail. Roy R. Lewis III's chapter in Methods and Criteria for Successful Mangrove Forest Restoration (2009) provide a well-rounded list of site selection and monitoring criteria to ensure 
the highest rates of success for mangrove introductions. Typical mangrove species zonation and saltwater inundation levels (Figure 22) should be considered carefully when identifying which taxa to introduce into a new location, to provide specific suites of ecosystem services.

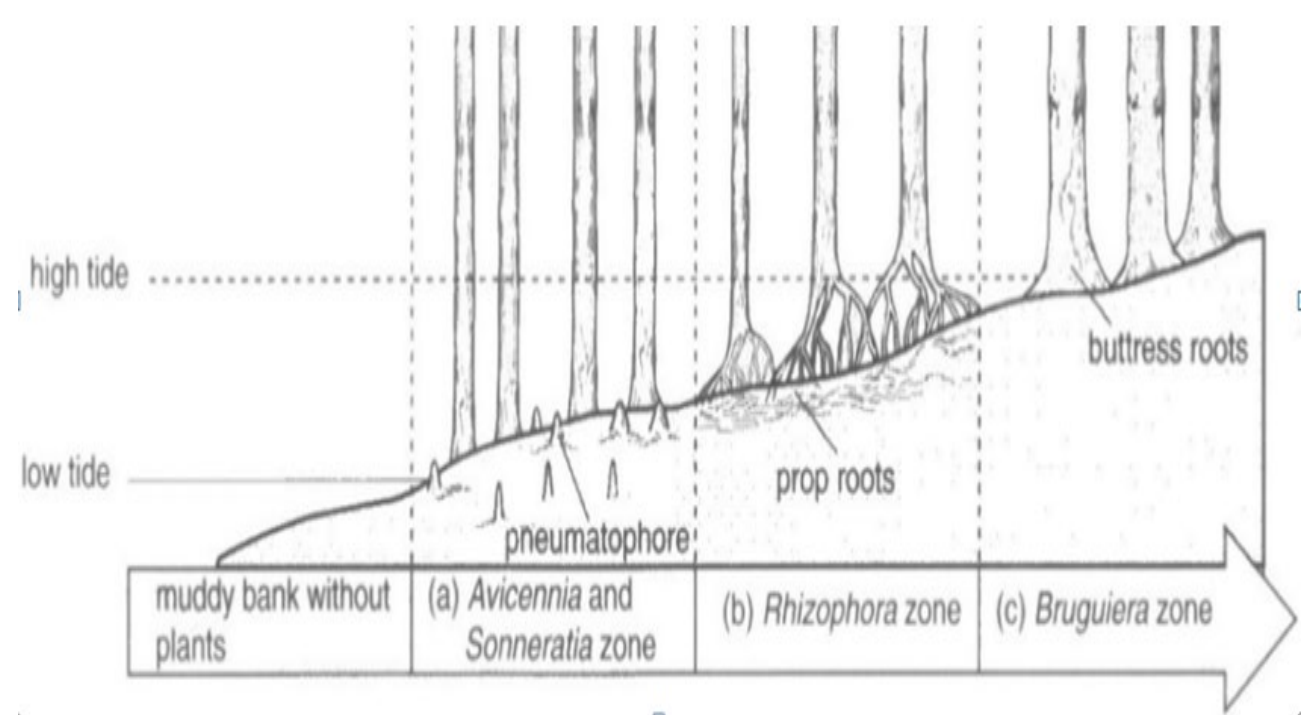

Figure 22: Illustration of typical mangrove zonation, showing the root style of dominant species at different intertidal zones (Slideshare.net).

These zones are not static from season to season, and a suite of ecological and geological variables interplay at any given moment to result in the observed community dynamics at any location (multi-variate statistical analyses are useful here). A thorough literature review was conducted by Krauss et al. (2008) on the specific environmental drivers that effect mangrove establishment and influence the successful development of early mangrove forests. They review advances in the current scientific understanding of how variables including temperature, carbon dioxide, salinity, light, nutrients, flooding, and specific biotic interactions effect mangrove seedling survival and growth rates. These variables should be examined during any preintroduction environemental assessment, to ensure environmental requirements are met prior to introduction attempts. With these cautions in mind, the following mangroves have been identified in the Marshall Islands, and it is recommended that the most geographically proximal population of suitable mangrove taxa be selected to enhance natural coastal buffers from climate change threats in the RMI (Figure 23). Locations like Namdrik Atoll, which hosts the only Ramsar International Mangrove Wetland (Ramsar, 2012) and the largest native mangrove habitat in the Marshall Islands may provide well acclimated seed stock to atolls within the maximum natural dispersal range of the species which make up this diverse zonated habitat. The standard Information Sheet for Ramsar Wetlands (RIS) is a suggested data template for pre and post mangrove introduction assessments and monitoring for any mangrove introductions conducted in the RMI, to ensure consistent and comparable data collection occurs at as many locations as possible and to maximize data collection benefits at individual monitoring locations. The Ramsar RIS monitoring data sheet can be found in the Hyperlinks section at the end of the Literature Cited (rsis.Ramsar.org). 


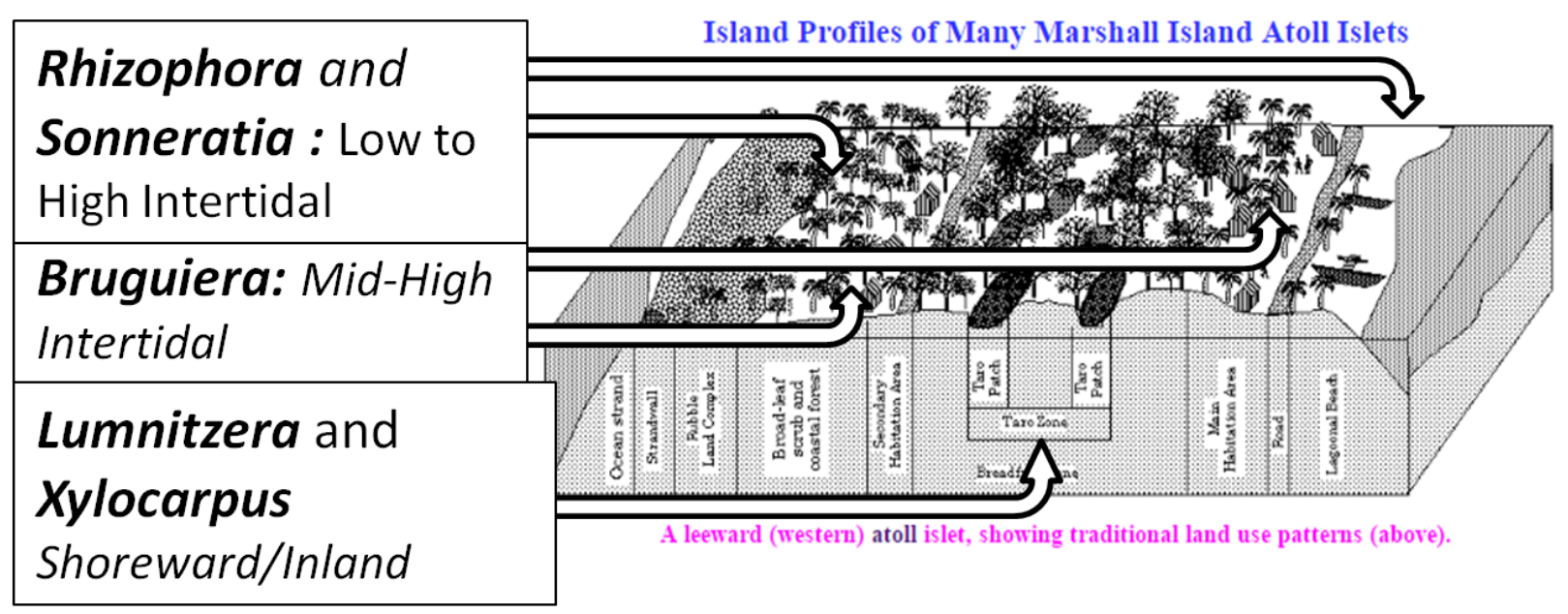

Figure 23: Common mangrove intertidal zonation in the RMI, showing where each mangrove taxa may have the highest success rates when introduced (modified from Spennemann, 1998).

\section{Bruguiera gymnorrhiza (Jon in Marshallese):}

Native Habitat: This is the dominant mangrove species in the Marshall Islands (Figure 24), and is the only species found on northern atolls (Ellison, 2007). Habitat requirements for black mangroves make them better suited for more protected and shoreward introduction locations, thriving in low to moderate salinities. The knee-roots of Bruguiera gymnorrhiza allow it to survive well in waterlogged soils that are not frequently disturbed, meaning tidally inundated yet not wave exposed.

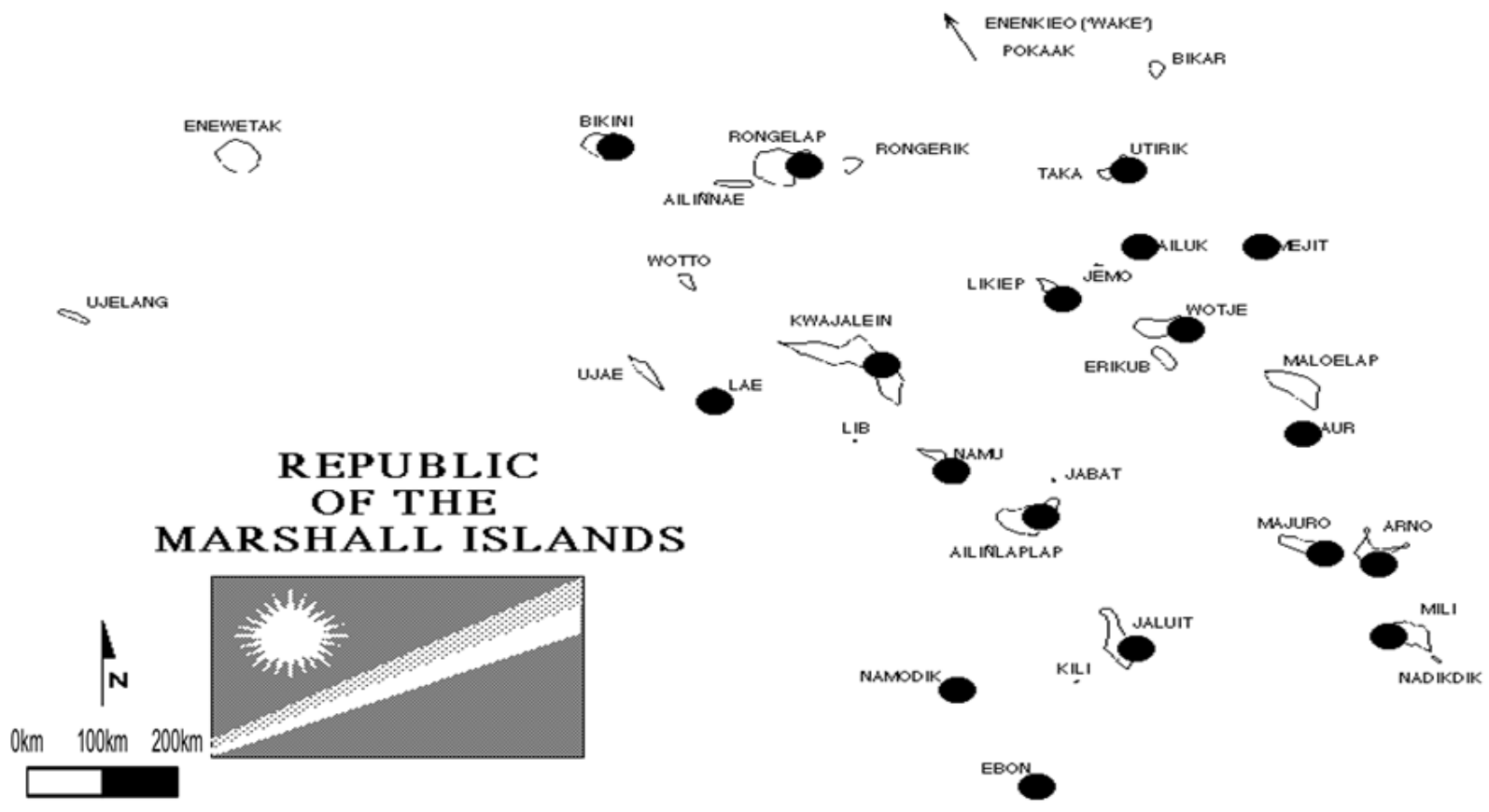

Figure 24: Distribution of the widest ranging native Marshallese mangrove genus Bruguiera (from Spennemann 1998).

Historical Uses: Like many mangrove species, B. gymnorrhiza contains anti-bacterial and anti-fungicidal phytochemicals. This makes them well suited for use as rot-resistant house posts, and Bruguiera (jon) in the Marshall Islands is traditionally boiled to soak and treat fishing nets to make them more durable from fungicidal properties imbued by the mangrove. This process is 
also used to make dark brown and black dyes form the fruits which are used to color items ranging from woven hand-crafts to classroom 'blackboards' for schoolrooms (Hawaii.edu). Extracted medicines from different parts of the jon are used alone or mixed into compounds with other plants to treat aliments including burns. Bruguiera's attractive red and yellow flowers have also led to them being planted in many ESI locations as well, including in Hawaii (Allen, 1998).

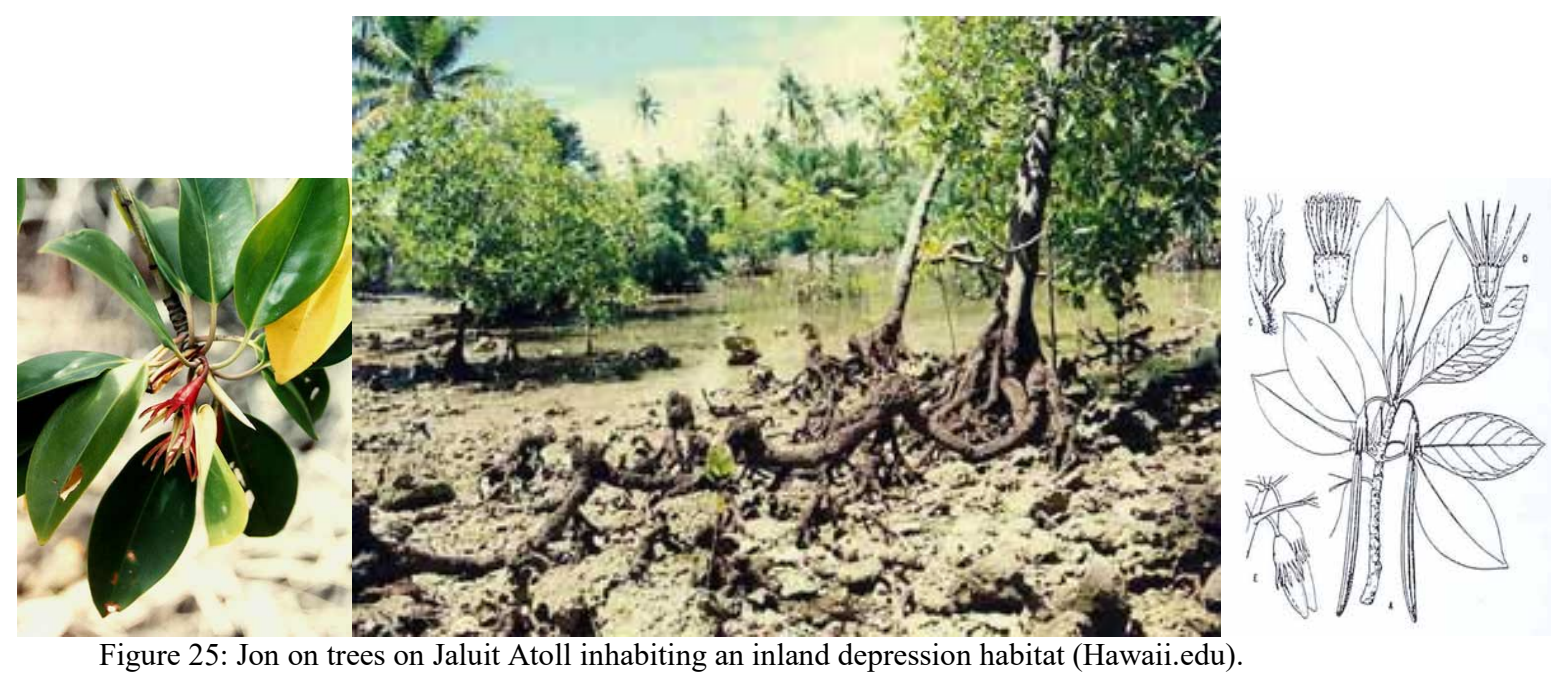

Projected Impacts from Introductions: Jon may be well suited for introduction into more temperate climates, and may therefore be suitable for introduction throughout the Marshall Islands. The habitat complexity provided by the knee-roots of Bruguiera in the mid to high intertidal zone may enhance terrestrial provisioning services such as coconut crabs, though not enhancing marine taxa as much as seaward Rhizophora or Sonneratia genera which are more deeply inundated to support fish foraging. However, a non-native freshwater eel known as a ton (Anguilla celebensis) inhabits the 'pat' (wetland ecosystems), in the southern Marshall Islands including inland depressions (Figure 25) supporting B. sexangula forests on Namdrik and Jaluit atolls. This apparent facilitation, or at least co-occurrence, may increase food provisioning if co-introduced.

Flower leis are constructed as necklaces in Hawaii from the durable flower from the different ESI Bruguiera sexangula indicates humans may find additional uses of this genus when introduced in onto new atolls.

\section{Lumnitzera littorea (Kimeme in Marshallese):}

Native Habitat: This shade intolerant black mangrove (Figure 26) does best in shoreward habitats in locations protected locations for weather and wave exposure (IUCN.org, 2015), being susceptible to physical damage similar to Bruguiera, though not as wide-spread. It is lacks a competitive advantage for sunlight, so is found in more exposed and potentially disturbed habitats as an early pioneer. 


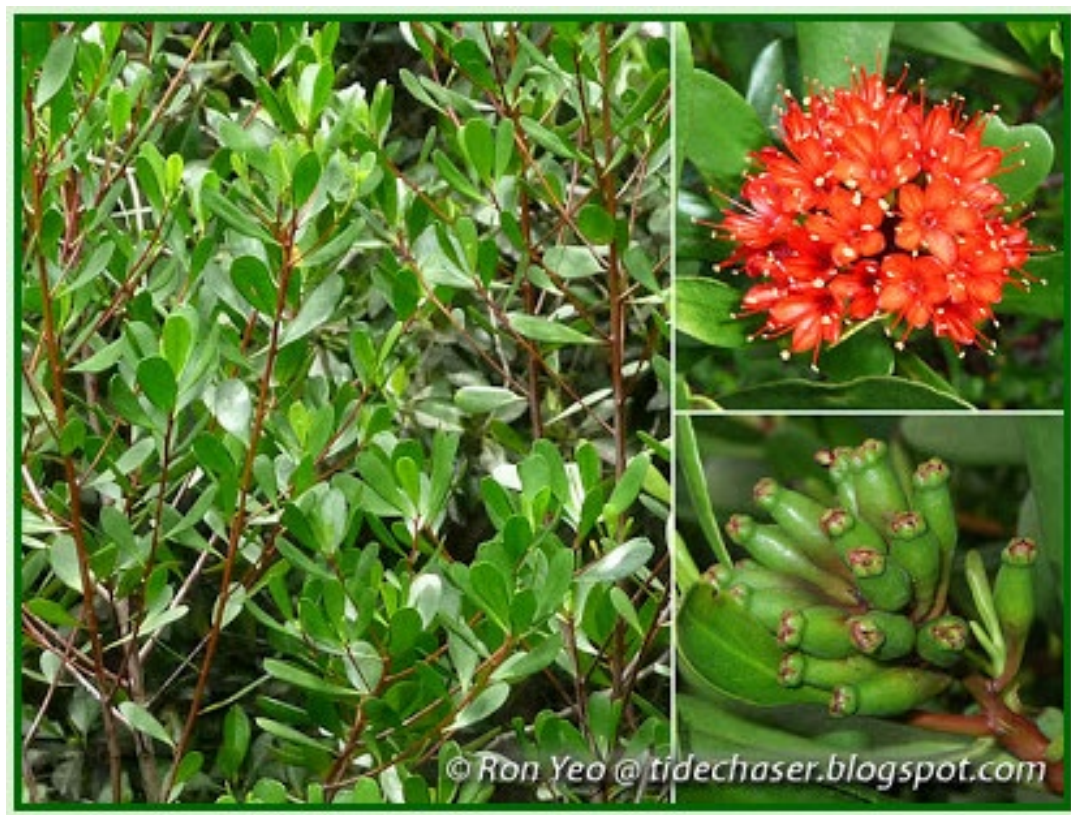

Figure 26: Lumnitzera littrea (Yeo, 2011).

Historical Uses: This native black mangrove to the Marshall Islands is valued for both its beautiful red flowers and strong timber used in outrigger and home construction. Wood planks made from Lumnitzera littrea tend to also be straighter with more clear vertical grain that most mangrove timber making well suited for constructing planks for shingles and boards.

Projected Impacts from Introduction: Direct provisioning resources could be provided to local atolls by introducing this species. Harvestable wood, however would take decadal time scales and this species appears poorly adapted to provide shoreward coastal protection from ocean wave exposure. It may have some competitive advantages and may succeed if Bruguiera introductions fail for some reason.

\section{Rhizophora mucronata and apiculata (Eoeak or Bulabol in Marshallese):}

Native Habitat: Ellison (2007) points out that many identified $R$. mucronata may potentially be $R$. apiculata (or even $R$. stylosa) in the RMI. Regardless of species, red mangrove is commonly found inhabiting the seaward edge of more exposed coastal habitats than many other mangrove genera. Rhizophora's expansive prop roots provide support against increased mechanical stresses from coastal exposure, yet ample light and nutrients allow them to thrive at the mangles edge. Their intricate prop roots (Figure 27) favor crustaceans and juvenile life-stages of fish, and less-so large adult fish as harvested from pencil-root Sonneratia alba, along more wave protected coastlines at high tide. 

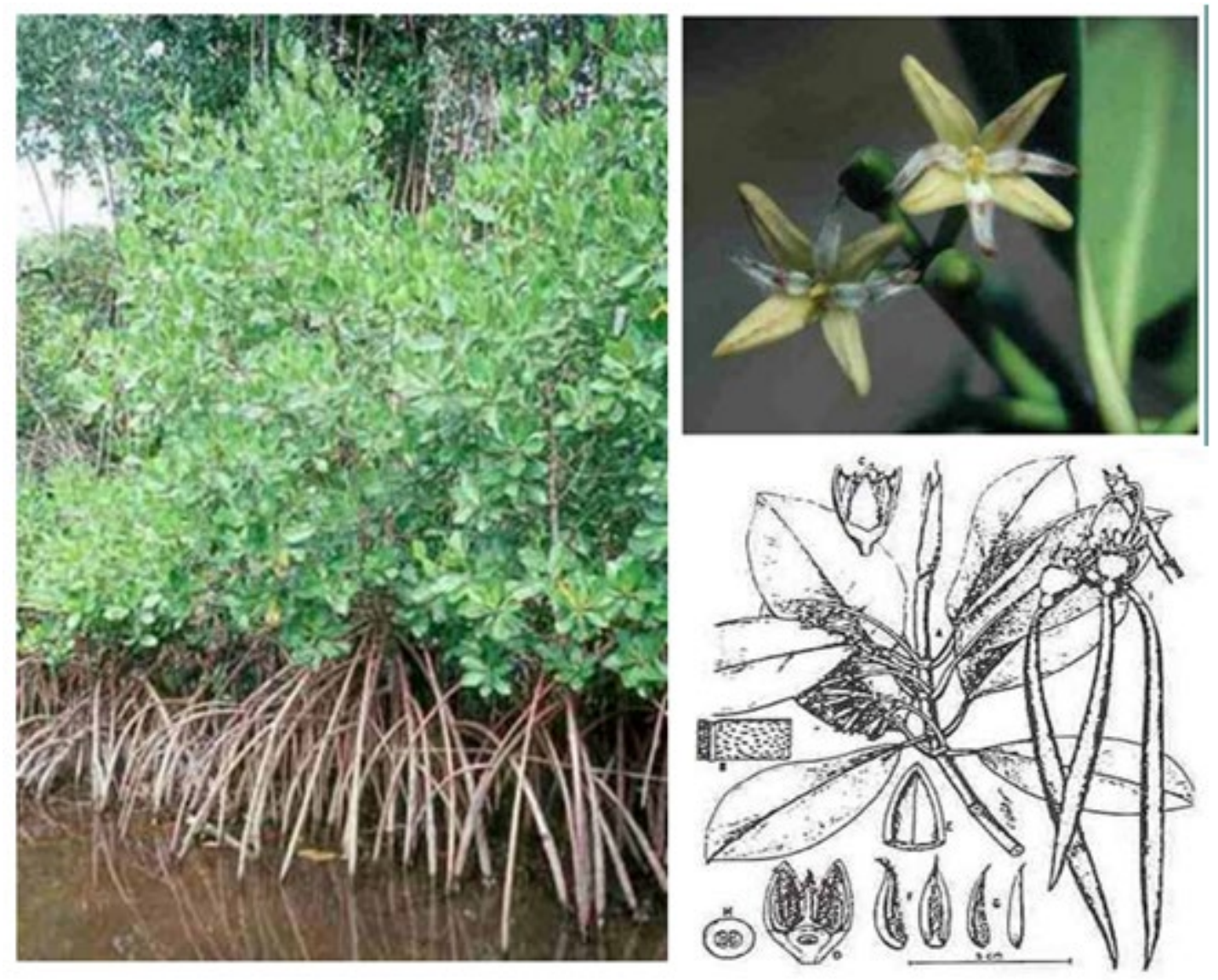

Figure 27: Some of the distinctive features of Rhizophora mucronata (Hawaii.edu).

Historical Uses: Rhizophora are used locally in the RMI for conditioning nets due to their fungicidal properties. The wood is used for construction, and the dense wood is an excellent source of fuel wood and is commonly for making charcoal. Their dense prop-roots are forage grounds for native wildlife as well as humans, and these prop-roots also provide superior protection from incoming waves and storm surge.

Projected Impacts from Introduction: R. murcronata was previously recorded on Jaluit Atoll, though it appears to no longer be present (Vander Veld and Vander Veld, 2005). This indicates the potential for them to have naturally colonized surrounding atolls in the past with their floating seed pod propagules that can remain viable up to one month. Historic inter-island transport should reduce the likely negative ecological impacts from human introductions of this Rhizophora species within the RMI. As they point out:

Fosberg \& Sachet (1962) and Fosberg et al. (1979) considered $R$. mucronata to be indigenous on Jaluit Atoll. The brief notation of only the collector and year by Fosberg \& Sachet (1962) and nothing further, gives no insight as to whether the Germans or Japanese might have actually introduced this species. The Marshallese name for Rhizophora spp. is "eoeak." It is quite different from most other Micronesian names for this species, but similar to the Pohnpeian "aak" for R. apiculata (Falanruw et al. 1990, Stemmermann 1981). Some Marshallese people, who do not know the word "eoeak" as being a tree, are familiar with the term pole for poling a canoe or boat (pers. comm. B. Kiotak). The species certainly could have been introduced for this and other purposes, as traditional sailing canoe travel between the Marshalls and Pohnpei, even in fairly recent times, has been documented (Tobin 2002). 
Provisioning of local coastal marine and terrestrial species is projected to increase as well, and as discussed, the greatest gains may be seen in harvested invertebrate taxa like crabs and shellfish directly utilizing prop root habitats. However, it is the increases in regulating services, including shoreline protection, which make Rhizophora such an appealing genus for introduction. Ailuk Atoll, for example, in the RMI has been selected for Rhizophora introductions with a goal of "enhancement of coastal protection against storms, sea-level rise and erosion, and enabling of natural products such as fish, crabs and wood (Ellison, 2007)."

\section{Sonneratia alba (Bulabol or Konpat in Marshallese):}

Native Habitat: The ability of this large mangrove species to inhabit lower intertidal zones with high salinity make this "white mangrove" an important provider of marine habitat complexity. Additionally it has been found to thrive in more inland habitats as well, and is known for supporting a wide range of biodiversity as it creates a hard substrate required for other species in their wetland environment.
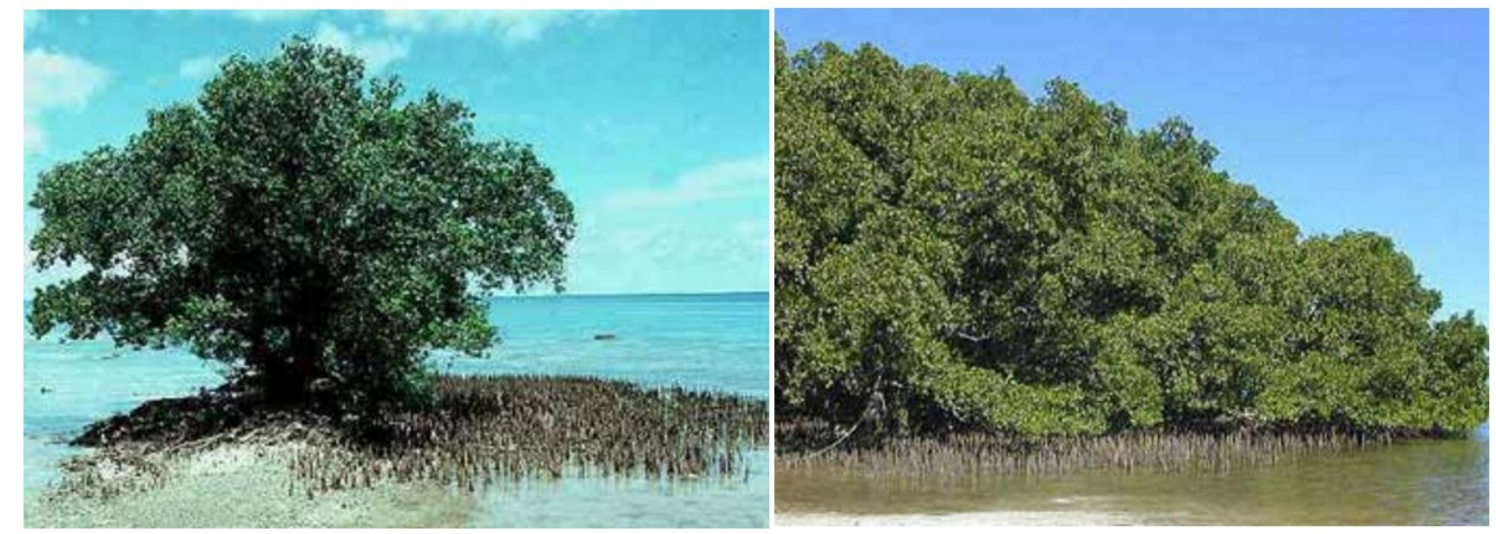

Figure 28: Pencil roots associated with Sonneratia alba are known for harboring high densities of fish species, which forage among/over them during high tide (Hawaii.edu).

Historical Uses: This rot resistant wood is used for constructing canoes and for floor timbers in the Marshall Islands. Few mangroves have the large size of its wood, with trunks exceeding 1.5 meters in diameter being recorded from some locations (Hawaii.edu). The high timber value greatly enhances its direct provisioning value. Pencil-roots (Figure 28) make foraging by fish easier in these habitats than in red mangrove prop-root habitats, and subsistence fishing is often productive in and around Sonneratia.

Projected Impacts from Introduction: Range expansions and new introductions of Sonneratia alba are expected to increase near-shore fish foraging habitat, and the seaward position of this species makes it well suited to block incoming ocean waves. Its ability to survive in a range of intertidal and inland habitats also may make it an excellent choice for mangrove introductions in variable coastal environments on smaller outer atolls. One major projected impact of introduction is the enhancements of epiphytes such as ferns and orchids, which have been shown to favor this species in particular, further enhancing local biodiversity. 


\section{Xylocapus rumphii/moluccensis (Lokobar in Marshallese):}

Native Habitat: This mangrove is found on Ae Island on Jaluit Atoll near Namdrik, and all Xylocapus in the RMI supposedly come from a single tree (Vander Velde and Vander Velde, 2005). The Vander Veldes found, after a large typhoon over Jaluit Atoll, Xylocapus debris was commonly found washing ashore in Majuro Atoll, roughly 200 kilometers away proving the potential for natural dispersal of this species already exists. They typically lack a substantial aerial root structure, typical of other mangroves, potentially making them less stable to mechanical stressors such as wind and waves.

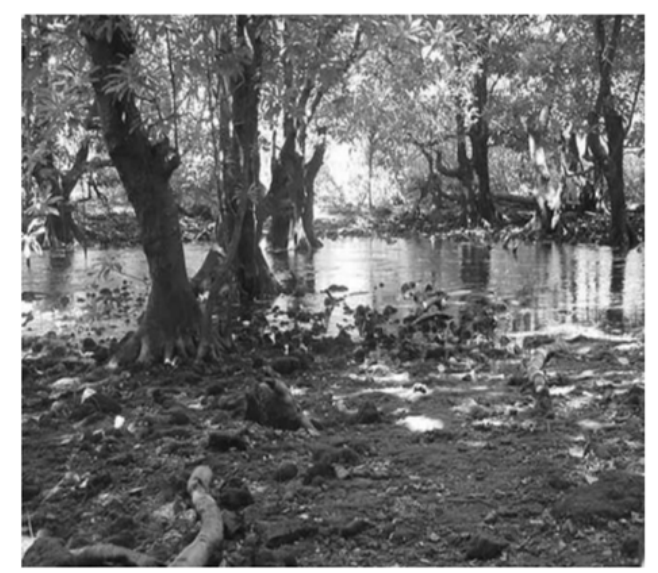

Figure 29: A young lokobar (Xylocapus) on Ae Islet on Jaluit Atoll tree (Vander Velde and Vander Velde, 2005).

Historical Uses: Used in traditional medicines, its bark is boiled to relieve gastric upset in other regions. Its hard wood is also valued for construction. Limited cultural use is reported for this species in the RMI, though subsistence used for fuelwood and constructions are expected when available. Populations of Xylocapus appear to be localized to Jaluit (Figure 29), yet seedpods, which are highly susceptible to predation (Figure 30), have been found on other atolls following major storms.

Projected Impacts of Introduction: Since this appears to be a fairly new arrival to the Marshall Islands, future research studying the spread of this species may provide valuable basic science research avenues regarding island biogeography. Educational and research opportunities such as these are examples of how rare mangrove species may still greatly enhance these cultural ecosystem services with increasing habitat complexity and stabilize sediments in more protected coastal environments.

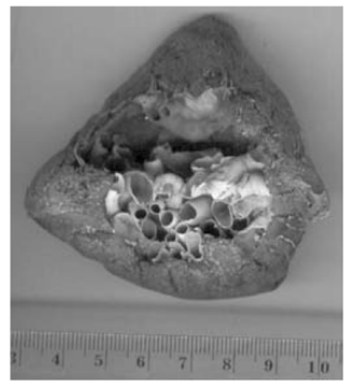

Figure 30: Even newly arrived Xylocapus seeds in are still very susceptible to native Marshallese herbivores and predators like these shipworms (Vander Velde and Vander Velde, 2005). 


\section{Final Ecosystem Service Synthesis and Precautions for the RMI:}

Enhancing the populations of the five genera in the RMI may provide coastal communities with increased food and fuel security by provisioning additional resources, such as crabs and fuelwood (Ellison, 2007). Yet the largest benefits to coastal communities in the RMI are likely to come from the enhancement of regulating ecosystem services. The ability of mangroves to slow coastal erosion by trapping sediments in their aerial roots, which also dissipate income wave energy from storm surges and sea level rise, provide a cost effective management strategy to buffer remote coastlines from climate change threats. Supporting services may become more apparent over time as nutrient cycling can be traced through isotopic or carbon to nitrogen analyses, for example. Improvements in cultural ecosystem services should become instantly apparent as mangrove rehabilitation projects build social capital in the Marshall Islands, as multiple islands become connected through shared natural resource projects. However, as Rudiak-Gould points out (2012), communications about climate change between citizens of the Republic of the Marshall Islands and the global scientific community must take care to include TEK dialog when developing local natural resource management plans. In the traditionally maritime Marshallese culture, this often means including spiritual and astronomical considerations during climate change dialogues. This ensures multi-directional flows of information and the inclusion of traditional ecological knowledge during adaptive management projects which are inclusive and supportive of indigenous viewpoints and customs on outer atolls in the RMI, where community resilience and perseverance is strong. It is areas like these which require assistance, however, to avoid local cultural extinction in a world rapidly forcing outside pressures upon even the most remote coastal communities in the Republic of the Marshall Islands.

Unfortunately, there are many unknowns regarding mangrove introductions, and coastal vegetation management in the face of climate change, in the Pacific. A recent report published by the United Nations Environmental Program (UNEP) highlights some key knowledge gaps in the side-by-side comparison table of baseline mangrove data throughout the region (Included as Appendix 2). These gaps provide direct insight into future research paths in the RMI particularly (Gilman et. al. 2006). However, with technological advances, many of these unanswered questions in this report may be quickly resolved. For example, new genetic sequencing and DNA techniques can be utilized to positively identify mangrove species, select appropriate strains for relocation, and detect hybridization events with co-occurring species (Harwood and Phillips, 2011).

The Republic of the Marshall Islands and Small Island Developing States in the Pacific face many challenges in the coming decades of climate change. Local culture and community survival depends on fostering proactive citizen based projects, which help individuals increase the beneficial ecosystem services in their region. Mangrove introduction and restoration efforts may prove to be a cost effective and time efficient method for helping the Marshallese accomplish this over the next decade.

Table 1 show the expected strength (1-5 numeric scale with stars for ease of visual comparisons) of enhancements to each ecosystem service category for all current RMI mangrove taxa. It also provides a guide for selecting taxa to match intertidal habitat and current geographic range. Root type is also provided in this table, due to the important differences in physical structure each produces in the mangle. 
Table 1: Key features of RMI mangroves and expected net gains in ecosystem services (1-5 scales, visually represented with stars).

\begin{tabular}{|c|c|c|c|c|c|c|c|c|c|c|}
\hline $\begin{array}{l}\text { Mangroves in } \\
\text { the RMI }\end{array}$ & $\begin{array}{c}\text { English } \\
\text { Name }\end{array}$ & $\begin{array}{l}\text { Marshall } \\
\text { ese Name }\end{array}$ & $\begin{array}{c}\text { Geographic } \\
\text { Range }\end{array}$ & $\begin{array}{c}\text { Intertidal } \\
\text { Zone }\end{array}$ & $\begin{array}{l}\text { Root } \\
\text { Type }\end{array}$ & $\begin{array}{c}\text { Terrestrial } \\
\text { Provisioning } \\
\text { ES Gain }\end{array}$ & $\begin{array}{c}\text { Marine } \\
\text { Provisioning } \\
\text { ES Gain }\end{array}$ & $\begin{array}{c}\text { Regulating } \\
\text { ES Gain }\end{array}$ & $\begin{array}{c}\text { Supporting } \\
\text { ES Gain }\end{array}$ & $\begin{array}{l}\text { Cultural } \\
\text { ES Gain }\end{array}$ \\
\hline $\begin{array}{c}\text { Bruguiera } \\
\text { gymnorrhiza }\end{array}$ & $\begin{array}{c}\text { Black } \\
\text { Mangrove }\end{array}$ & Joñ & $\begin{array}{c}5 \\
* * * * * \\
\text { Rōnlap- } \\
\text { Ebon }\end{array}$ & $\begin{array}{l}\text { High } \\
\text { /Inland }\end{array}$ & Knee & $\begin{array}{c}5 \\
* * * * *\end{array}$ & $\begin{array}{l}2 \\
* *\end{array}$ & $\begin{array}{l}2 \\
* *\end{array}$ & $\begin{array}{c}4 \\
* * * *\end{array}$ & $\begin{array}{c}5 \\
* * * * *\end{array}$ \\
\hline $\begin{array}{c}\text { Luminitzera } \\
\text { littorea }\end{array}$ & $\begin{array}{c}\text { Black } \\
\text { Mangrove }\end{array}$ & Kimeme & $\begin{array}{c}2 \\
* * \\
\text { Jaluit }\end{array}$ & $\begin{array}{l}\text { High } \\
\text { /Inland }\end{array}$ & Knee & $\begin{array}{c}5 \\
* * * * *\end{array}$ & $\begin{array}{l}2 \\
* *\end{array}$ & $\begin{array}{l}2 \\
* *\end{array}$ & $\begin{array}{c}4 \\
* * * *\end{array}$ & $\begin{array}{c}4 \\
* * * *\end{array}$ \\
\hline $\begin{array}{c}\text { Rhizophora } \\
\text { apiculata }\end{array}$ & $\begin{array}{c}\text { Red } \\
\text { Mangrove }\end{array}$ & $\begin{array}{l}\text { Būlabol̦ } \\
\text { or eoeak }\end{array}$ & $\begin{array}{c}1 \\
* \\
\text { Jaluit }\end{array}$ & Low & Prop & $\begin{array}{c}3 \\
* * *\end{array}$ & $\begin{array}{c}3 \\
* * *\end{array}$ & $\begin{array}{c}5 \\
* * * * *\end{array}$ & $\begin{array}{c}3 \\
* * *\end{array}$ & $\begin{array}{l}2 \\
* *\end{array}$ \\
\hline $\begin{array}{c}\text { Rhizophora } \\
\text { mucronata }\end{array}$ & $\begin{array}{c}\text { Red } \\
\text { Mangrove }\end{array}$ & $\begin{array}{l}\text { Būlabol̦ } \\
\text { or eoeak }\end{array}$ & $\begin{array}{c}3 \\
* * * \\
\text { Ailinlaplap } \\
\text { to Ebon }\end{array}$ & Low & Prop & $\begin{array}{c}3 \\
* * *\end{array}$ & $\begin{array}{c}3 \\
* * *\end{array}$ & $\begin{array}{c}5 \\
* * * * *\end{array}$ & $\begin{array}{c}3 \\
* * *\end{array}$ & $\begin{array}{c}3 \\
* * *\end{array}$ \\
\hline Sonneratia alba & $\begin{array}{c}\text { White } \\
\text { Mangrove }\end{array}$ & $\begin{array}{c}\text { Būlaboḷ } \\
\text { or Kōnpat }\end{array}$ & $\begin{array}{c}4 \\
* * * * \\
\text { Ailinlaplap } \\
\text { to Ebon }\end{array}$ & $\begin{array}{c}\text { Low to } \\
\text { High }\end{array}$ & Pencil & $\begin{array}{l}2 \\
* *\end{array}$ & $\begin{array}{c}4 \\
* * * *\end{array}$ & $\begin{array}{c}3 \\
* * *\end{array}$ & $\begin{array}{c}3 \\
* * *\end{array}$ & $\begin{array}{c}5 \\
* * * * *\end{array}$ \\
\hline $\begin{array}{c}\text { Xylocarpus cf. } \\
\text { rumphii }\end{array}$ & $\begin{array}{c}\text { Puzzle- } \\
\text { Nut or } \\
\text { Mahogan } \\
\text { y } \\
\text { Mangrove }\end{array}$ & Lokobar & $\begin{array}{c}1 \\
* \\
\text { Jaluit }\end{array}$ & $\begin{array}{l}\text { High } \\
\text { /Inland }\end{array}$ & $\begin{array}{l}\text { Mostly } \\
\text { Lacking }\end{array}$ & $\begin{array}{l}1 \\
*\end{array}$ & $\begin{array}{l}1 \\
*\end{array}$ & $\begin{array}{l}1 \\
*\end{array}$ & $\begin{array}{l}1 \\
*\end{array}$ & $\begin{array}{l}1 \\
*\end{array}$ \\
\hline
\end{tabular}


Advantageously for introduction projects, mangroves inhabit a narrow shoreline niche making them relatively easy to monitor as populations expand on small islands and atolls. Tracking population dynamics as mangroves establish and spread at introduction sites will help local managers ensure the success of their projects, while also providing a research platform for a wide range of scientific investigations into island biogeography, ecological succession, population genetics, and climate change adaptation in a relatively controlled research system on secluded Pacific atolls.

Monthly to yearly monitoring plans for introduction sites may follow the Information Sheet on Ramsar Wetlands (RIS) (rsis.Ramsar.org) to collect standardized general data, with more technical scientific monitoring methods examining variables including nutrient cycling, physiological requirements, and environmental tolerances outlined in Krauss et al. (2008), for example. This information can provide valuable baseline data for Long Term Ecological Monitoring (LTER) on the effects of mangrove introductions in the RMI. Should assessments indicate that certain introduced mangrove populations are impacting critical native habitat, or other negative impacts are detected, immediate mechanical removal of these populations is recommended-with seed propagule monitoring and removal on a yearly basis as required.

Put bluntly by Roy and Connell several years ago (1991), Pacific Islanders living on small atolls "may become the first environmental refugees of the greenhouse era." Although enhancing shoreline vegetation may be a cost effective and less ecologically disruptive strategy than engineered methods for coastal protection (such as sea-wall construction), human assisted range expansion of mangroves has had a wide range of positive and negative impacts on historic ecosystem services and coastal communities around the globe. However, developing cost effective and sustainable projects to buffer coastlines against climate change impacts is imperative for the survival of many communities and local customs in the Republic of the Marshall Islands. 


\section{LITERATURE CITED:}

Allen, J. A. 1998. Mangroves as Alien Species: The Case of Hawaii. Global Ecology and Biogeography Letters, 7 (1): 61-71.

Alongi, D.M. 2002. Present State and Future of the World's Mangrove Forests. Environmental Conservation, 29(3): 331-349.

Barbier, E.B., Hacker, S.D., Kennedy, C., Koch, E.W., Stier, A.C., Sillman, B.R. 2011. The Value of Estuarine and Coastal Ecosystem Services. Ecological Monographs, 81(2): 169-193.

Bell, J. and Lovelock, C.E. 2013. Insuring Mangrove Forests for Their Role in Mitigating Coastal erosion and Storm-Surge: An Australian Case Study. Wetlands, 33: 279-289.

Benton, N., J.D. Ripley, and F. Powledge (Editors). 2008. Conserving Biodiversity on Military Lands: A Guide for Natural Resources Managers. 2008 edition. The Nature Conservancy, Arlington, Virginia. 220 pages.

Bertness, M. D., S. D. Gaines, and M. Hay (Editors). 2001. Marine Community Ecology, Sinauer Associates. Sunderland, Massachusetts. 550 pages.

Bostrom, C., Pittman, S.J., Simenstad, C., Kneib, R.T. 2011. Seascape Ecology of Coastal Biogenic Habitats: Advances, Gaps, and Challenges. Marine Ecology Progress Series, 437: 191217.

Bouchez, A., Pascault, N., Chardon, C., Bouvy, M., Cecchi, P., Lambs, L., Herteman, M., Fromard, F., Got, P., Leboulanger, C. 2013. Mangrove Microbial Diversity and the Impact of Trophic Contamination. Marine Pollution Bulletin, 66: 39-46.

Brander, L.M., Florax, R.J.G.M., Vermaat, J.E. 2006. The Empirics of Wetland Valuation: A Comprehensive Summary and a Meta-Analysis of the Literature. Environmental and Resource Economics, 33: 223-250.

Bruno, J.F. 2003. Inclusion of Facilitation into Ecological Theory. Trends in Ecology and Evolution, 18(3): 119-125.

Chapin, M.H., Wood, K.R., Perlman, S.P., Maunder, M. 2004. A Review of the Conservation Status of the Endemic Prichardia Palms of Hawaii. Oryx, 38(3): 273-281.

Chen, LL., Tan, NN.F.Y., Huang, J. Zeng, X., Meng, X., Zhong, C., Wong, Y., Lin, G. 2008. Comparison of Ecophysiological Characteristic between Introduced and Indigenous Mangrove Species in China. Estuarine, Coastal and Shelf Science, 79: 644-652.

Chaikin, S. 2012. "No Shrimp of a Business." Molokai Dispatch [Kaunakakai, HI]. June 13"th 2012. https://themolokaidispatch.com/no-shrimp-of-a-business/ 
Conchedda, G., Lambin, E.F., Mayaux, P. 2011. Between Land and Sea: Livelihoods and Environmental Changes in Mangrove Ecosystems of Senegal. Annals of American Geographers, 101(6): 1259-1284.

Conservation International. 2008. Economic Values of Coral Reefs, Mangroves, and Seagrasses: A Global Compilation. Center for Applied Biodiversity Science, Conservation International, Arlington, VA, USA: 23 pages.

Danielsen, F., Sorensen, M.K., Olwig, M.F., Selvam, V., Parish, F., Burgess, N.D., Hiraishi, T., Karunagaran, V.M., Rasmussen, M.S., Hansen, L.B., Quarto, A., Suryadiputra, N. 2005. The Asian Tsunami: A Protective Role for Coastal Vegetation. Science, 310: 643.

Davis, M.A., Chew, M.K., Hobbs, R.J., Lugo, A.E., Ewel, J.J., Vermeij, G.J., Brown, J.H., Rosenzweig, M.L., Gardener, M.R., Carroll, S.P., Thompson, K., Pickett, S.T.A., Stromberg, J.C., Tredici, P.D., Suding, K.N., Ehrenfeld, J.G., Grime, P., Mascaro, J., Briggs, J.C. 2011. Don't Judge Species on their Origins. Nature, 474: 153-154.

Dehghani, M., Farshchi, P., Danekar, A., Karami, M., Aleshikh, A.A. 2010. Recreational Value of Hara Biosphere Reserve Using Willingness-to-Pay Method. International Journal of Environmental Research, 4(2): 271-280.

Demopoulos, A.W.J., Fry, B., Smith, C.R. 2007. Food Web Structure in Exotic and Native Mangroves: A Hawaii-Puerto Rico Comparison. Oceologia, 153: 675-686.

Demopoulos, A.W.J. and Smith, C.R. 2010. Invasive Mangroves Alter Macrofaunal Community Structure and Facilitate Opportunistic Exotics. Marine Ecology Progress Series, 404: 51-67.

D’Iorio, M., Jupiter, S.D., Cochran, S.A., Potts, D.C. 2007. Optimizing Remote Sensing and GIS Tools for Mapping and Managing the Distribution of an Invasive Mangrove (Rhizophora mangle) on South Molokai, Hawaii. Marine Geodesy, 30: 1-2.

Dibbons-Young. 2013: "State Epidemic Threatens Endangered Waterfowl." The Molokai Dispatch. Sept $18^{\text {th }}, 2013$.

Donato, D.C., Kauffman, J.B., Murdiyarso, D., Kurnianto, S., Stidham, M., Kanninen, M. 2011. Mangroves Among the Most Carbon-Rich Forests in the Tropics. Nature Geoscience Letters, 4: 293-297.

Dorenbosch, M., van Riel, M.C., Nagelkerken, I., Vander Velde, G. 2004. The Relationship of Reef Fish Densities to the Proximity of Mangroves and Seagrass Nurseries. Estuarine, Coastal and Shelf Science, 60: 37-48.

Dorenbosch, M., Grol, M.G.G., Christianen, M.J.A., Nagelkerken, I., and Vander Velde, G. 2005. Indo-Pacific Seagrass Beds and Mangroves Contribute to Fish Density and Diversity on Adjacent Coral Reefs. Marine Ecology Progres Series, 302: 63-76.

Drigot, D.C., Wilcox B.A. and Duin K.N. 2001. Marine Corps Base Hawaii Integrated Natural Resources Management Plan and Environmental Assessment (MCBH INRMP/EA), 2002-2006. 
Prepared through Geo InSight International, Inc. for Environmental Department, Marine Corps Base Hawaii (MCBH), Oahu:

Duffy, D., Frasher, H.R., Parker-Geisman, V., Parish, G.R. III. 2007. Hawaiian Hoary Bat Inventory in National Parks on the Islands of Hawaii, Maui, and Molokai. Pacific Cooperative Studies Unit, University of Hawaii, Manoa. 28 pages.

Ellison, J. 2007. "Mangrove and Possible Mangrove Introduction Sites at Ailuk Atoll, Marshall Islands." Natural Resource Assessment Survey (NRAS): 28 pages.

Emerton, L. and L.D.C.B. Kekulandala. 2003. Assessment of the Economic Value of Muthurajawela Wetland. Occasional Papers of International Union Conservation of Nature, Sri Lanka, 4(4): 28 pages.

Escobedo, F., Varela, S., Zhao, M., Wagner, J.E., Zipperer, W. 2010. Analyzing the Efficacy of Subtropical Urban Forests in Offsetting Carbon Emissions from Cities. Environmental Science and Policy, 13:362-370.

Everard, M., Jha, R.R.S., Russell, S. 2014. The Benefits of Fringing Mangrove Systems to Mumbai. Aquatic Conservation: Marine and Freshwater Ecosystems, 24: 256-274.

Farnsworth, E. J., and A. M. Ellison. 1997. Global patterns of pre-dispersal propagule predation in mangrove forests. Biotropica, 29: 318-330.

Farber, J. 1997. “Ancient Hawaiian Fishponds: Can Restoration Succeed on Molokai?” Neptune House Publications. Encinitas, CA. 100 pages.

Feder, J.L., Chilcote, C.A., Bush, G.L. 1988. Genetic Differentiation between Sympatric Host Races of the Apple Maggot Fly Rhagoletis pomonella. Nature, 336: 61-64.

Field, M.E., Cochran, S.A., Logan, J.B., and Storlazzi C.D. (Editors). 2008. The Coral Reef of South Moloka'i, Hawai'i: Portrait of a Sediment-Threatened Fringing Reef. U.S. Geological Survey Scientific Investigations, Report 2007-5101, 180 pages.

Finn, M. 1996. The Mangrove Mesocosm of Biosphere 2: Design, Establishment and Preliminary Results. Ecological Engineering, 6: 21-56.

Fourqurean, J.W., Smith, T.J. III, Possley, J., Collins, T.M., Lee, D., Namoff, S. 2010. Are Mangroves in the Tropical Atlantic Ripe for Invasion? Exotic Mangrove Trees in the Forests of Southern Florida. Biological Invasions, 12: 2509-2522.

Fronda, R., M. Lane-Kamahele, Harry, B. and D. Duffy. 2008. Removal of alien red mangrove from Kaloko Honokohau National Historical Park. Pacific Cooperative Studies Unit Technical Report 162, University of Hawaii at Manoa, Department of Botany, Honolulu, HI. 14 pages.

Fry, B. and N. Cormier. 2011. Chemical Ecology of Red Mangroves, Rhizophora mangle, in the Hawaiian Islands. Pacific Science, 65(2): 219-234. 
Garrison, Jennifer S.E., Mark J. Rauzon, Kristin N. Duin, Bruce A. Wilcox. 2002. Marine Corp Base Hawaii Invasive Species Management Study (ISMS). Final Report. Prepared through: Naval Facilities Engineering Service Center. Port Hueneme, California, for Environmental Department, Marine Corps Base Hawaii.

Gedan, K.B., Kirwan, M.L., Wolanski, E., Barbier, E.B., Silliman, B.R. 2011. The Present and Future Role of Coastal Wetland Vegetation in Protecting Shorelines: Answering Recent Challenges to the Paradigm. Climate Change, 106: 7-29.

Genthner, F.J., Lewis, M.A, Nestlerode, J.A., Elonen, C.M., Chancy, C.A., Teague, A., Harwell, M.C., Moffett, M.F., Hill, B.H. 2013. Relationships Among Habitat Quality and Measured Condition Variables in Gulf of Mexico Mangroves. Wetlands Ecological Management, 21: 173191.

Gilman, E., H. Van Lavieren, J. Ellison, V. Jungblut, L. Wilson, F. Areki, G. Brighouse, J. Bungitak, E. Dus, M. Henry, I. Sauni Jr., M. Kilman, E. Matthews, N. Teariki-Ruatu, S. Tukia, K. Yuknavage. 2006. Pacific Island Mangroves in a Changing Climate and Rising Sea. UNEP Regional Seas Reports and Studies No. 179. United Nations Environment Programme, Regional Seas Programme, Nairobi, KENYA.

Harwood, A.S. and Phillips, R.B. 2011. A suite of twelve single nucleotide polymorphism markers for detecting introgression between cutthroat and rainbow trout. Molecular Ecology Resources, 11: 382-5.

Hergazy, I., Mesbah, N., Colby, M. 2002. A Survey of Red Sea Tourists' and Tourism Operators' Willingness to Pay for Coral Reef Conservation. Egyptian Environmental Policy Program. 128 pages.

Hogarth, Paul. 2007. The Biology of Mangroves and Seagrasses. Oxford University Press. Oxford, UK. 273 pages.

Hoopes, M.F. and L.M. Hall. 2002. Edaphic Factors and Competition Affect Patter Formation and Invasion in a California Grassland. Ecological Applications, 12(1): 24-39.

Hubbell, S.P. 2005. Neutral Theory in Community Ecology and the Hypothesis of Functional Equivalence. Functional Ecology, 19: 166-172.

Igulu, M.M., Nagelkerken, I., van der Velde, G., Mgaya, Y.D. 2013. Mangrove Fish Production is Largely Fueled by External Food Sources: A Stable Isotope Analysis of Fishes at the Individual, Species, and Community Levels from Across the Globe. Ecosystems, 16: 1336-1352.

IPCC (Intergovernmental Panel on Climate Change). 2014: Climate Change 2014: Synthesis Report. Contribution of Working Groups I, II and III to the Fifth Assessment Report of the Intergovernmental Panel on Climate Change [Core Writing Team, R.K. Pachauri and L.A. Meyer (eds.)]. IPCC, Geneva, Switzerland. 151 pages.

IUCN (International Union for the Conservation of Nature). 2005. Mangroves of Pakistan: Status and Management. International Union for the Conservation of Nature. 121 pages. 
Jones, C.G., Lawton J.H., Shachak, M. 1994. Organisms as ecosystem engineers. Oikos, 69: 373386.

Jones, T.G., Ratsimba, H.R., Ravaoarinorotsihoarana, L., Cripps, G., Bey, A. 2014. Ecological Variability and Carbon Stock Estimates of Mangrove Ecosystems in Northwestern Madagascar. Forests, 5: 177-205.

Kauffman, J.B., Heider, C., Cole, T.G., Dwire, K.A., Donato, D.C. 2011. Ecosystem Carbon Stocks of Micronesian Mangrove Forests. Wetlands, 31: 343-352.

Kauffman, J.B., Heider, C., Norfolk, J., Payton, F. 2014. Carbon Stocks of Intact Mangroves and Carbon Emissions Arising from their Conversion in the Dominican Republic. Aquatic Botany, 24(3): 518-527.

Keala, G., Hollyer, J.R., Castro, L. 2007. “Loko I'a: A Manual on Hawaiian Fishpond Restoration and Management." College of Tropical Agriculture and Human Resources, University of Hawaii, Manoa: 74.

Keane, R.M. and Crawley, M.J. 2002. Exotic Plant Invasions and the Enemy Release Hypothesis. Trends in Ecology and Evolution, 17(4): 164-170.

Kimirei I.A., Nagelkerken I., Mgaya Y.D., and C.M. Huijbers. 2013. The Mangrove Nursery Paradigm Revisited: Otolith Stable Isotopes Support Nursery-to-Reef Movements by IndoPacific Fishes. PLoS ONE, 8(6): e66320.

Kobsa, B.A. 2010. "Mangrove Eradication within Reach on Hawai'i Island". Hawaii Wetland Monitor, the newsletter of the Hawaii Wetland Joint Venture [Hilo, HI]. May 2010. 3-4.

Koch, E.W., Barbier, E.B., Silliman, B.R., Reed, D.J., Perillo, G.M.E., Hacker, S.D., Granek, E.F., Primavera, J.H., Muthiga, N., Polasky, S., Halpern, B.S., Kennedy, C.J., Kappel, C.V., Wolanski, E. 2009. Non-Linearity in Ecosystem Services: Temporal and Spatial Variability in Coastal Protection. Frontiers in Ecology and the Environment, 7(1): 29-37.

Krauss, K.W., Lovelock, C.E., McKee, K.L., Lopez-Hoffman, L., Ewe, S.M.L., Sousa, W.P. 2008. Environmental Drivers in Mangrove Establishment and Early Development: A Review. Aquatic Botany, 89: 105-127.

Krauss, K.W. and Allen, J.A. 2003. Influence of Salinity and Shade on Seedling Photosynthesis and Growth of Two Mangrove Species, Rhizophora mangle and Bruguiera sexangula, Introduced to Hawaii. Aquatic Botany, 77: 311-324.

Langer, M.R. and Lipps, J.H. 2006. Assembly and Persistence of Foraminifera in Introduced Mangroves on Moorea, French Polynesia. The Micropaleontology Project, 52(4): 343-355.

Lau, W.W.Y. 2013. Beyond Carbon: Conceptualizing Payments for Ecosystem Services in Blue Forests on Carbon and Other Marine and Coastal Ecosystem Services. Ocean and Coastal Management, 83: 5-14. 
Leung, J.Y.S., and N.F.Y. Tam. 2013. Influence of Plantation of an Exotic Mangrove Species, Sonneratia caseolaris, on Macrobenthic Infaunal Community in Futian Mangrove National Nature Reserve, China. Journal of Experimental Marine Biology and Ecology, 448: 1-9.

Lewis, R. R. III. 2009. "Methods and Criteria for Successful Mangrove Forest Restoration.” In: Gerardo M. E. Perillo, Eric Wolanski, Donald R. Cahoon, Mark M. Brinson, (Editors). "Coastal Wetlands: An Integrated Ecosystem Approach.” Elsevier. Amserterdam. 787 pages.

Li, C.H., Zhou, H.W., Wong, Y.S., Tam, N.F.Y. 2009. Vertical Distribution and Anaerobic Biodegradation of Polycyclic Aromatic Hydrocarbons in Mangrove Sediments in Hong Kong, South China. Science of the Total Environment, 407: 5772-5779.

Li, F., Yang, Q., Zan, Q., Tam, N.F.Y., Shin, P.K.S., Vrijmoed, L.L.P., Cheung, S.G. 2011. Differences in Leaf Construction Cost Between Alien and Native Mangrove Species in Futian, Shenzhen, China, Marine Pollution Bulletin, 62: 1957-1962.

Liu, H., Ren, H., Hui, D., Wang, W., Liao, B., Cao, Q. 2014. Carbon Stocks and Potential Carbon Storage in the Mangrove Forests of China. Journal of Environmental Management, 133: 86-93.

Livesley, S.J. and Andrusiak, S.M. 2012. Temperate Mangrove and Salt Marsh Sediments are a Small Methane and Nitrous Oxide Source but Important Carbon Store. Estuarine, Coast and Shelf Science, 97: 19-27.

Lockwood, J.L., Hoopes, M.F., Marchetti, M.P. 2007. "Invasion Ecology.” Blackwell Publishing, MA. 304 pages.

Lu, W., Yang, S., Chen, L., Wang, W., Du, X., Wang, C., Ma, Y., Lin, G., Lin, G. 2014. Changes in Carbon Pool and Stand Structure of a Native Subtropical Mangrove Forest after Inter-Planting with Exotic Species Sonneratia apetala. PLoS ONE, 9(3): e91238.

MacArthur, R.H. and E. O. Wilson. 1967. The Theory of Island Biogeography. Princeton University Press. 199 pages.

MacKenzie, R.A. and Kryss. 2012. Impacts of Exotic Mangroves and Chemical Eradication of Mangroves on Tide Pool Fish Assemblages. Marine Ecology Progress Series, 472: 219-237.

Marina, A.; Asbjornsen, H.; Baker, L. A.; Brozovic, N.; Drinkwater, L. E.; Drzyzga, S. A.2011. Research on Coupled Human and Natural Systems (CHANS): Approach, Challenges, and Strategies. Bulletin of the Ecological Society of America, 92: 218-228.

McIver, Viney, K. Harley, D. Hanna, L. and Kienene, T. 2015. Climate change, overcrowding and non-communicable diseases: The 'triple whammy' of tuberculosis transmission risk in Pacific atoll countries. The Annals of the ACTM: An International Journal of Tropical and Travel Medicine, 16(3): 57-62.

McIver, L., Kim, R., Woodward, A., Hales, S., Spickett, J., Katscherian, D., Hashizume, M., Honda, Y., Kim, H., Iddings, S., Naicker, J., Bambrick, H., McMichael, A.J., and K. L. Ebi. 
2015 Health Impacts of Climate Change in Pacific Island Countries: A Regional Assessment of Vulnerabilities and Adaptation Priorities. Environmental Health Perspectives DOI: 10.1289/ehp.1509756 Advance Publication: Not Copyedited.

McLeod, E., Chmura, G.L., Bouillon, S., Salm, R. Bjork, M., Duarte, C.M., Lovelock, C.E., Schlesinger, W.H., Silliman, B.R. 2011. A Blueprint for Blue Carbon: Toward an Improved Understanding of the Role of Vegetated Coastal Habitats in Sequestering $\mathrm{CO}_{2}$. Frontiers in Ecology, 9(10): 552-560.

McMahon, K.W., Berumen, M.L., Thorrold, S.R. 2012. Linking Habitat Mosaics and Connectivity in a Coral Reef Seascape. Proceedings of the National Academy of Science, 109(38): 15372-15376.

McNally, C.G., Uchida, E., Gold, A.J. 2011. The Effect of a Protected Area on the Tradeoffs between Short-Run and Long-Run Benefits from Mangrove Ecosystems. Proceedings of the National Academy of Science, 108(34): 13945-13950.

MEA (Millennium Ecosystem Assessment), 2005. "Millennium Ecosystem Assessment: Ecosystems and Human Well-being: Wetlands and Water Synthesis." Island Press, Washington, DC.

Mumby, P.J., Edwards, A.J., Arias-Gonzalez, J.E., Lindeman, K.C., Blackwell, P.G., Gall, A., Gorcznska, M.I., Harorne, A.R., Pescod, C.L., Renken, H., Wabnitz, C.C.C., Llewellyn, G. 2004. Mangroves Enhance the Biomass of Coral Reef Fish Communities in the Caribbean. Letters to Nature, 427: 533-536.

Nagelkerken, I., Blaber, S.J.M., Bouillon, S., Green, P., Haywood, M., Kirton, L.G., Meynecke, J.O., Pawlik, J., Penrose, H.M., Sasekumar, A., Somerfield, P.J. 2008. The Habitat Function of Mangroves for Terrestrial and Marine Fauna: A Review. Aquatic Botany, 89: 155-185.

Nakahara, B. 2007. Utilization of mangrove habitat by megafauna along the south coast of Molokai. Master's Thesis. University of Hawaii Manoa, Honolulu. 69 pages.

O'Garra, T. 2012. Economic Valuation of a Traditional Fishing Ground on the Coral Coast in Fiji. Ocean and Coastal Management, 56: 44-55.

Pernetta, J.C., Ong, J.E., Padilla, N.EE.O., Rahim, K.A., Chinh, N.T. 2013. Determining Regionally Applicable Economic Values for Coastal Habitats and their Use In Evaluating the Cost Effectiveness of Regional Conservation Actions: The Example of Mangroves, in the South China Sea. Ocean and Coastal Management, 85: 177-185.

Perry, C.T. and A. Berkeley. 2009. Intertidal Substrate Modification as a Result of Mangrove Planting: Impacts of Introduced Mangrove Species on Sediment Microfacies Characteristics. Estuarine, Coastal and Shelf Science, 81: 225-237.

Peterson, A.T., Soberon, J., Sanchez-Cordero, V. 1999. Conservatism of Ecological Niches in Evolutionary Time. Science, 285(5431): 1265-1267. 
Polidoro, B.A., Carpenter, K.E., Collins, L., Duke, N.C., Ellision, A.M., Ellison, J.C., Farnsworth, E.J., Fernando, E.S., Kathiresan, K., Koedam, N.E., Livingstone, S.R., Miyagi, T., Moore, G.E., Nam, V.N., Ong, J.E., Primavera, J.H., Salmo, S.G. III., Sanciangco, J.C., Sukardjo, S., Wang, Y., Yong, J.W.H. 2010. The Loss of Species: Mangrove Extinction Risk and Geographic Areas of Global Concern. PLoS ONE, 5(4): e10095.

Primavera, J.H. 1998. Mangroves as Nurseries: Shrimp Populations in Mangrove and NonMangrove Habitats. Estuarine, Coastal and Shelf Science, 46: 457-464.

Ramsar. 2012. "Marshall Islands Designates Near-Pristine Atoll [Namdrik].” Ramsar Convention Secretariat. August 24 ${ }^{\text {th }}, 2012$.

Rauzon, M. J. and D.C. Drigot. 2001. Red Mangrove Eradication and Pickleweed Control in a Hawaiian Wetland, Waterbird Responses, and Lessons Learned. Turning the Tide: The Eradication of Invasive Species, 240-248.

Ren, H., Lu, H., Shen, W., Huang, C., Guo, Q., Li, Z., Jian, S. 2009. Sonneratia apetala in the Mangrove Ecosystems of China: An Invasive Species or Restoration Species? Ecological Engineering, 35: 1243-1248.

Rudiak-Gould, P. 2012. Promiscuous corroboration and climate change translation: A case study from the Marshall Islands. Global Environmental Change, 22(1): 46-54.

Ronnback, P., Troell, M., Kautsky, N., Primavera, J.H. 1999. Distribution Pattern of Shrimps and Fish among Avicenna and Rhizophora Microhabitats in the Pagbilao Mangroves, Philippines. Estuarine, Coastal and Shelf Science, 48: 223-234.

Roy, P. and J. Connell. 1991. Climate Change and the Future of Atoll States. Journal of Coastal Research, 7(4): 1057-1075.

Salem, M.E. and D.E. Mercer. 2012. The Economic Value of Mangroves: A Meta-Analysis. Sustainability, 4: 359-383.

Santiago, L.S., Lau, T.S., Melcher, P.J., Steele, O.C., Goldstein, G. 2000. Morphological and Physiological Response of Hawaiian Hibiscus tiliaceus Populations to Light and Salinity. International Journal of Plant Sciences, 161(1): 99-106.

Santos, H.F., Carmo, F.L., Paes, J.E.S., Rosado, A.S., Peixoto, R.S. 2011. Bioremediation of Mangroves Impacted by Petroleum. Water, Air and Soil Pollution, 216: 329-350.

Sarkar, S.K. and A.K. Bhattacharya. 2003. Marine Pollution Bulletin, 47: 260-264.

Satyanarayana, B., Bhanderi, P., Derby, M., Maniatis, D., Fore, F., Badgie, D., Jammeh, K., Vanwing, T., Farcy, C., Koedam, N., Dahdouh-Guebas, F. 2012. A Socio-Ecological Assessment Aiming at Improving Forest Resource Management and Sustainable Ecotourism Development in the Mangroves of Tanbi Wetland National Park, The Gambia, West Africa. AMBIO, 41:513-526. 
Sax, D.F., Stachowicz, J.J., Gaines, S.D. (Editors). 2005. Species Invasions: Insights into Ecology, Evolution, and Biogeography. Sinauer Associates Inc. MA. 481 pages.

Simberloff. D. and B.Von Holle. 1999. Positive Interactions of Nonindigenous Species: Invasional Meltdown? Biological Invasions, 1: 21-32.

Siple, M.C. and M.J. Donahue. 2013. Invasive Mangrove Removal and Recovery: Food Web Effects across a Chronosequence. Journal of Experimental Marine Biology and Ecology, 448: 128-135.

Sousa, W.P. 1979. Disturbance in Marine Intertidal Boulder Fields: The Nonequalibrium maintenance of Species Diversity. Ecology, 60(6): 1225-1239.

Spennemann, Dirk H.R. (1998). "Traditional utilization of Mangroves in the Marshall Islands." Digital Micronesia, Albury.

Steele, O.C., Ewel, K.C., Goldstein, G. 1999. The Importance of Propagule Predation in a Forest of Non-Indigenous Mangrove Trees. Wetlands, 19(3): 705-708.

Sweetman, A.K., Middelburg, J.J., Berle, A.M., Bernardino, A.F., Schander, C., Demopoulos, A.W,J., Smith, C.R. 2010. Impacts of Exotic Mangrove Forests and Mangrove Deforestation on Carbon Remineralization and Ecosystem Functioning in Marine Sediments. Biogeochemistry, 7: 2129-2145.

Taylor, F.J. 1979. Rhizophora in the Society Islands. Pacific Science, 33(2): 173-176.

Tilman, D. 2004. Niche Tradeoffs, Neutrality, and Community Structure: A Stochastic Niche Theory of Resource Competition, Invasion, and Community Assembly. Proceedings of the National Academy of Science, 101(30): 10854-10861.

Vander Velde, N. and Vander Velde, B. 2005. Two Species of Mangrove Trees Previously Unrecorded in the Marshall Islands found on Jaluit Atoll. Micronesica. 37(2):297-308.

Vilardy, S.P., Gonzalez, J.A., Martin-Lopez, B. Montes, C. 2011. Relationships between Hydrological Regime and Ecosystem Services Supply in a Caribbean Coastal Wetland: A SocioEcological Approach. Hydrological Sciences Journal, 56(8): 1423-1435.

Vo, Q.T., Kuenzer, C., Vo, Q.M., Moder, F., Oppelt, N. 2012. Review of Valuation Methods for Mangrove Ecosystem Services. Ecological Indicators, 23: 431-446.

Volmann-Kohlmeyer, B. and J. Kohlmeyer. 1993. Biogeographic Observations on Pacific Marine Fungus. Mycology, 85(3): 337-346.

Walters, B.B., Ronnback, P., Kovacs, J.M., Crona, B., Hussain, S.A., Badola, R., Barbier, E., Dahdouh-Guebas, F. 2008. Ethnobiology, Socio-Economics and Management of Mangrove Forests: A Review. Aquatic Botany, 89: 220-236.

Warren-Rhodes, K., Schwarz, A.M., Boyle, L.N., Albert, J., Agalo, S.S., Warren, R., Bana, A., Paul, C., Kodosiku, R., Bosma, W., Yee, D., Ronnback, P., Crona, B., Duke, N. 2011. Mangrove 
Ecosystem Services and the Potential for Carbon Revenue Programmes in Solomon Islands. Environmental Conservation, 38(4): 485-496.

Williams, M.J., Coles, R., Primavera, J.H. 2007. A Lesson From Cyclone Larry: An Untold Story of the Success of Good Coastal Planning. Estuarine, Coastal and Shelf Science, 71: 364367.

Whitesell, C.D. 1984. Silvical Characteristics of Koa (Acacia koa gray). U.S. Forest Service Research Papers, PSW-16: 1-17.

Woodrow, R.J., Grace, J.K., Yates, J.R. III. 1999. "Hawaii’s Termites: An Identification Guide." CTAHR (College of Tropical Agriculture and Human Resources ) Household and Structural Pests. 6 pages.

Xin, K., Zhou, Q., Arndt, S.K., Yang, X. 2013. Invasive Capacity of the Mangrove Sonneratia apetala in Hainan Island, China. Journal of Tropical Forest Science, 25(1): 70-78.

Yang, Q. Tam, N.F.Y., Wong, Y.S., Luan, T.G., Su, W.S., LAn, C.Y., Shin, P.K.S., Cheung, S.G. 2008. Potential Use of Mangroves as Constructed Wetland for Municipal Sewage Treatment in Futian, Shenzhen, China. Marine Pollution Bulletin, 57: 735-743.

\section{Hyperlinks: \\ External document links that relate to mangroves and mangrove ecosystem services around the globe}

Aceh, Indonesia Mangroves: Rafie

http://www.slideshare.net/iswandono1/mangrove-biodiversity-in-aceh

The Dongzhai Port Nature Reserve and Mangroves on Hainan Island, Guangdong Province, China: UNESCO

http://whc.unesco.org/en/tentativelists/105/

Mangroves of Egypt as Tourist Destinations along the Red Sea: FAO

http://www.fao.org/3/a-ae213e/ae213e05.htm

Hara Biosphere Reserve and Mangroves in Iran: UNESCO

http://www.unesco.org/mabdb/br/brdir/directory/biores.asp? mode=all\&code $=\mathrm{IRA}+05$

Mangroves of Molokai, Hawaii: Ka Honua Monona Community Stakeholder Molokai, HI http://www.kahonuamomona.org with special thanks for field monitoring assistance and honored Personal Communications with Uncle Mervin Dudoit at fishpond restoration sites near Kaunakakai, Molokai, 2012: http://www.kahonuamomona.org/about/kupuna-council-2/uncle-mervin-dudoit

Mangroves in the Muthurajawela Marsh and Wetlands in Sri Lanka: IUCN https:/cmsdata.iucn.org/downloads/casestudy01muthurajawela.pdf 
Mangroves of Pakistan: IUCN

http://www.waterinfo.net.pk/sites/default/files/knowledge/Mangroves $\% 20 \mathrm{of} \% 20$ Pakistan $\% 20$ -

\%20Status\%20and\%20Management.pdf

Mangrove of the Pacific: Photo Identification and Resources: Wild Singapore

http://www.wildsingapore.com/wildfacts/plants/mangrove/mangroves.htm

Mangroves on Pacific Islands and Climate Change: UNEP

Gilman et al. 2006. Pacific Island Mangroves in a Changing Climate and Rising Sea:

http://www.unep.org/PDF/mangrove-report.pdf

Mangroves and Plants of the Republic of the Marshall Islands: Hawaii.edu

http://www.Hawaii.edu/cpis/MI/

Mangroves in the RMI and Pacific Climate Change Adaptation: Community Stakeholders for Various

Pacific Islands: SPREP

https://www.sprep.org/biodiversity-ecosystems-management/mangroves-in-the-marshall-islands-to-protect-local$\underline{\text { communities }}$

Mangrove Uses in the RMI: Digital Micronesia

Spennemann, Dirk H.R. (1998). Traditional utilization of Mangroves in the Marshall Islands. Digital

Micronesia. Aubry:

http://marshall.csu.edu.au/Marshalls/html/mangroves/mangroves.html

Mangrove Monitoring Sheets for the Marshall Islands: (RIS) Information (and Datasheets) for Ramsar

Wetland Monitoring in the Marshall Islands: Ramsar

https://rsis.ramsar.org/RISapp/files/RISrep/MH2072RIS.pdf

RMI Traditional Culture, Stories, and Photos:

http://mistories.org/intro.php

Mangroves in the Sundarbans: India/Bangladesh: WWF

http://wwf.panda.org/about_our_earth/ecoregions/sundarbans_mangroves.cfm

Mangroves in the Tanbi Wetland Complex in Gambia: Access Gambia

http://www.accessgambia.com/information/tanbi.html

Photographic Comparisons of Common Mangrove Species: Ron Yeo, Tidechaser

Yeo, Ron. 2011. http://tidechaser.blogspot.com/2011/11/identifying-true-mangrove-plants-of.html 


\section{EXTENDED LINKS}

Conserving Biodiversity on Military Lands: TNC

Benton, N., J.D. Ripley, and F. Powledge (Editors). 2008. Conserving Biodiversity on Military Lands: A Guide for Natural Resources Managers. The Nature Conservancy, Arlington, Virginia. 220 pages. In Particular: See Welde, T. Chapter 7: Invasive Species Management on Military Lands. http://www.dodbiodiversity.org/Full_Publication_Conserving_Biodiversity_on_Military_Lands.pdf

A Global Economic Valuation of Mangrove and Adjacent Ecosystems: CI

Conservation International. 2008. Economic Values of Coral Reefs, Mangroves, and Seagrasses: A Global

Compilation: http://www.icriforum.org/sites/default/files/Economic_values_global\%20compilation.pdf

Intergovernmental Panel on Climate Change's $5^{\text {th }}$ Global Assessment: IPCC

https://www.ipcc.ch/pdf/assessment-report/ar5/syr/SYR_AR5_FINAL_full_wcover.pdf

Living Islands NGO: Namdrik Atoll, RMI, and Portland OR, USA

http://www.livingislands.org

Millennium Ecosystem Assessment - Wetlands and Water Synthesis: MEA

Millennium Ecosystem Assessment, 2005. "Ecosystems and Human Well-Being: Wetlands and Water Synthesis.

World Resources Institute, Washington, DC.

http://www.millenniumassessment.org/documents/document.358.aspx.pdf

Molokai's Endangered Shorebird Conservation: Sponsors Community Stakeholder Molokai, HI

Dibbons-Young. 2013: "State Epidemic Threatens Endangered Waterfowl." The Molokai Dispatch. Sept 18 ${ }^{\text {th }}, 2013$. https://themolokaidispatch.com/state-epidemic-threatens-endangered-waterfowl

Molokai Shrimp Farms near Original Mangrove Introduction Site in Hawaii: Community Stakeholder Molokai, HI

Chaikin, S. 2012. "No Shrimp of a Business." Molokai Dispatch [Kaunakakai, HI]. June 13 ${ }^{\text {th }}, 2012$.

https://themolokaidispatch.com/no-shrimp-of-a-business

Pinterest of Samoan Crabs (Scylla serrata) on Oahu:

https://www.pinterest.com/pin/499688521127574505/

\section{Recommended Citation:}

Harwood, A.S. 2016. Mangrove Enhancement as a Climate Change Adaptation Strategy

in the Republic of the Marshall Islands (RMI): Potential Ecosystem Service Shifts Following Colonization. Living Islands NGO; Lake Oswego, OR.

Acknowledgements: This project was made possible by a National Science Foundation GK-12 Fellowship, a Fellowship through the Institute for Sustainable Solutions at Portland State University, and close partnership with Kianna Juda-Angelo and Jesper Angelo, Executive Director and Co-Founder of the Community Partner for this Project, Living Islands NGO. Special thanks to the Marshallese community and supporters in the Pacific Northwest including Portland State University President Wim Wiewel and Melissa Bennett at the Native American Student and Community Center, as well as an extended thanks to the President of the Republic of the Marshall Islands Christopher Loeak and staff who graced Living Islands and Portland State University by visiting the traditional Marshallese outrigger build site. Assistance by reviewers of this document, including Dr. Yangdong Pan, Dr. Joseph Maser, Dr. Bridget Deemer, the Adjunct Equality Foundation, and Ms. Alice Harwood are greatly appreciated as well. 


\section{APPENDIX 1 \\ STATEMENT of NEED from LIVING ISLANDS NGO \\ Requesting Assistance to: \\ Determine Potential Environmental Impacts form Introducing Mangrove Trees as a Climate Change Adaptation Strategy in the Republic of the Marshall Islands:}

"Living Islands NGO is a non-political, non-religious registered not-for-profit organization of volunteers committed to creating self-sufficient Pacific Islands that will serve as an example to communities all around the world. They are registered under the Marshall Islands Revised Code's Non-Profit Corporation Act (18 MIRC Ch. 3) in the Republic of the Marshall Islands [RMI] and as a registered 501(c)3 tax exempt not-for-profit organization in the United States of America. With a focus on sustainable practices and environmental education, our initiatives are designed to protect the natural resources of Pacific Islands while celebrating and strengthening its vibrant culture (LI Mission Statements, 2015)."

Living Islands has expressed the need for assistance in understanding the potential changes resulting from introducing mangrove trees as a climate change adaptation strategy to protect coastlines in The Republic of the Marshall Islands. Living Islands (LI) is aware that both beneficial and detrimental shifts to local natural resources have occurred following the introduction of some mangrove species in the Pacific, therefor LI requests assistance in examining the intertwining suite of potential environmental changes that mangrove introductions may elicit. To cover the multiple facets of this request, the ecosystem services framework (MEA, 2005) is utilized to explore how various types of mangrove introductions around the globe have both positively and negatively affected provisioning, regulating, supporting, and cultural benefits from nature which sustain human health and well-being (ecosystem services). A review of current scientific literature provides the foundation (and resource base) for making management recommendations regarding mangrove introductions in the Republic of the Marshall Islands (RMI) and other regions around the globe. 


\section{APPENDIX 2 \\ Key Literature Table:}

Table 1 groups some of the key mangrove ecosystem service literature used in developing hypotheses about how non-native mangrove colonization may affect ecosystem service provisioning in novel locations around the globe. References within each ecosystem service category are listed alphabetically by author. Full references are located in the Literature Cited section of the main document.

TABLE A1: Quick Literature Reference Guide

\begin{tabular}{|c|c|c|c|c|}
\hline ES CATEGORY & $\begin{array}{l}\text { LOCATIO } \\
\mathrm{N}\end{array}$ & $\begin{array}{l}\text { ESI, SSI, } \\
\text { or } \\
\text { NATIVE } \\
\text { (N) }\end{array}$ & $\begin{array}{l}\text { TAXA/PROCE } \\
\text { SS INVOLVED }\end{array}$ & REFERENCES \\
\hline \multicolumn{5}{|c|}{ PROVISIONING SERVICES } \\
\hline \multirow{12}{*}{ FISHERIES } & $\begin{array}{l}\text { Gulf of } \\
\text { California }\end{array}$ & $\mathrm{N}$ & Fisheries & $\begin{array}{l}\text { Aburto-Oropeza et } \\
\text { al. } 2009\end{array}$ \\
\hline & $\begin{array}{l}\text { Global } \\
\text { Review }\end{array}$ & $\mathrm{N}$ & Fisheries & Bostrom et al. 2008 \\
\hline & Hawaii & ESI & Crustaceans & $\begin{array}{l}\text { Demopoulos and } \\
\text { Smith, } 2010\end{array}$ \\
\hline & Tanzania & $\mathrm{N}$ & Reef Fish & $\begin{array}{l}\text { Dorenbosch et al. } \\
2004\end{array}$ \\
\hline & Indo-Pacific & $\mathrm{N}$ & Reef Fish & $\begin{array}{l}\text { Dorenbosch et al. } \\
2005\end{array}$ \\
\hline & $\begin{array}{l}\text { Tanzania } \\
\text { and } \\
\text { Indonesia }\end{array}$ & $\mathrm{N}$ & Reef Fish & Igulu et al. 2013 \\
\hline & Hawaii & ESI & $\begin{array}{l}\text { Tidepool } \\
\text { Assemblages }\end{array}$ & $\begin{array}{l}\text { MacKenzie and } \\
\text { Kryss, } 2013\end{array}$ \\
\hline & Red Sea & $\mathrm{N}$ & Reef Fish & $\begin{array}{l}\text { McMahon et al. } \\
2012\end{array}$ \\
\hline & Caribbean & $\mathrm{N}$ & Reef Fish & Mumby et al. 2004 \\
\hline & $\begin{array}{l}\text { Global } \\
\text { Review }\end{array}$ & $\mathrm{N}$ & Reef Fish & $\begin{array}{l}\text { Nagelkerken et al. } \\
2008\end{array}$ \\
\hline & Hawaii & ESI & Crustaceans & Nakahara, 2007 \\
\hline & Philippines & $\mathrm{N}$ & $\begin{array}{l}\text { Shrimp and } \\
\text { Prawns }\end{array}$ & Primavera, 2008 \\
\hline
\end{tabular}




\begin{tabular}{|c|c|c|c|c|}
\hline & Philipines & $\mathrm{N}$ & $\begin{array}{l}\text { Shrimp, Prawns } \\
\text { and Fish }\end{array}$ & $\begin{array}{l}\text { Ronnback et al. } \\
1999\end{array}$ \\
\hline \multirow{3}{*}{$\begin{array}{c}\text { FUEL \& } \\
\text { CONSTRUCTION }\end{array}$} & Senegal & $\mathrm{N}$ & $\begin{array}{l}\text { Fuel and } \\
\text { Construction }\end{array}$ & $\begin{array}{l}\text { Conchedda et al. } \\
2011\end{array}$ \\
\hline & Tanzania & $\mathrm{N}$ & Fuel Wood & McNally et al. 2011 \\
\hline & $\begin{array}{l}\text { Global } \\
\text { Review } \\
\end{array}$ & $\mathrm{N}$ & $\begin{array}{l}\text { Fuel and } \\
\text { Construction }\end{array}$ & Walters et al. 2008 \\
\hline \multirow{2}{*}{$\begin{array}{l}\text { MEDICINAL \& } \\
\text { ORNIMENTAL }\end{array}$} & Hawaii & ESI & $\begin{array}{l}\text { Non-Native } \\
\text { Mangroves }\end{array}$ & $\begin{array}{l}\text { Krauss and Allen, } \\
2003\end{array}$ \\
\hline & $\begin{array}{l}\text { Global } \\
\text { Review }\end{array}$ & $\mathrm{N}$ & Multiple & Walters et al. 2008 \\
\hline \multicolumn{5}{|c|}{ REGULATING SERVICES } \\
\hline \multirow{11}{*}{$\begin{array}{c}\text { COASTAL } \\
\text { PROTECTION }\end{array}$} & Hawaii & ESI & $\begin{array}{l}\text { Sediment } \\
\text { Control }\end{array}$ & Allen, 1998 \\
\hline & Australia & $\mathrm{N}$ & $\begin{array}{l}\text { Wave } \\
\text { Attenuation }\end{array}$ & $\begin{array}{l}\text { Bell and lovelock, } \\
2013\end{array}$ \\
\hline & $\begin{array}{l}\text { Indian } \\
\text { Ocean }\end{array}$ & $\mathrm{N}$ & $\begin{array}{l}\text { Wave } \\
\text { Attenuation }\end{array}$ & $\begin{array}{l}\text { Danielsen et al. } \\
2005\end{array}$ \\
\hline & Hawaii & ESI & $\begin{array}{l}\text { Sediment } \\
\text { Control }\end{array}$ & D'Iorio et al. 2007 \\
\hline & India & $\mathrm{N}$ & $\begin{array}{l}\text { Wave } \\
\text { Attenuation }\end{array}$ & Everard et al. 2014 \\
\hline & Hawaii & ESI & $\begin{array}{l}\text { Sediment } \\
\text { Control }\end{array}$ & Field et al. 2009 \\
\hline & $\begin{array}{l}\text { Global } \\
\text { Review }\end{array}$ & $\mathrm{N}$ & $\begin{array}{l}\text { Wave } \\
\text { Attenuation }\end{array}$ & Gedan et al. 2011 \\
\hline & $\begin{array}{l}\text { Global } \\
\text { Review }\end{array}$ & $\mathrm{N}$ & $\begin{array}{l}\text { Wave } \\
\text { Attenuation }\end{array}$ & Koch et al. 2009 \\
\hline & Rodrigues & ESI & $\begin{array}{l}\text { Sediment } \\
\text { Control }\end{array}$ & $\begin{array}{l}\text { Perry and Berkeley, } \\
2009\end{array}$ \\
\hline & $\begin{array}{l}\text { Indian } \\
\text { Ocean }\end{array}$ & $\mathrm{N}$ & $\begin{array}{l}\text { Wave } \\
\text { Attenuation }\end{array}$ & Walters et al. 2008 \\
\hline & Australia & $\mathrm{N}$ & $\begin{array}{l}\text { Wave } \\
\text { Attenuation }\end{array}$ & Willams et al. 2007 \\
\hline \multirow{2}{*}{$\begin{array}{c}\text { CARBON } \\
\text { SEQUESTRATION, } \\
\text { NUTRIENT CYCLING, } \\
\text { and STAND }\end{array}$} & $\begin{array}{l}\text { Hainan } \\
\text { Province, } \\
\text { China }\end{array}$ & SSI & $\begin{array}{l}\text { Non-Native } \\
\text { Mangroves }\end{array}$ & Chen et al. 2008 \\
\hline & Global & $\mathrm{N}$ & Carbon & Donato et al. 2011 \\
\hline
\end{tabular}




\begin{tabular}{|c|c|c|c|c|}
\hline \multirow[t]{15}{*}{ STRUCTURE } & Review & & Sequestration & \\
\hline & Florida & SSI & Stand Structure & $\begin{array}{l}\text { Escobedo et al. } \\
2010\end{array}$ \\
\hline & Hawaii & ESI & Nutrient Cycling & $\begin{array}{l}\text { Fry and Cormier, } \\
2011\end{array}$ \\
\hline & Madagascar & $\mathrm{N}$ & $\begin{array}{l}\text { Carbon } \\
\text { Sequestration }\end{array}$ & Jones et al. 2014 \\
\hline & Micronesia & $\mathrm{N}$ & $\begin{array}{l}\text { Carbon } \\
\text { Sequestration }\end{array}$ & $\begin{array}{l}\text { Kauffman et al. } \\
2011\end{array}$ \\
\hline & $\begin{array}{l}\text { Dominican } \\
\text { Republic }\end{array}$ & $\mathrm{N}$ & $\begin{array}{l}\text { Carbon } \\
\text { Sequestration }\end{array}$ & $\begin{array}{l}\text { Kauffman et al. } \\
2014\end{array}$ \\
\hline & $\begin{array}{l}\text { Global } \\
\text { Review }\end{array}$ & $\mathrm{N}$ & $\begin{array}{l}\text { PES Blue } \\
\text { Carbon }\end{array}$ & Lau, 2013 \\
\hline & China & SSI & $\begin{array}{l}\text { Construction } \\
\text { Costs }\end{array}$ & Li et al. 2011 \\
\hline & China & SSI & $\begin{array}{l}\text { Carbon } \\
\text { Sequestration }\end{array}$ & Liu et al. 2014 \\
\hline & Australia & $\mathrm{N}$ & $\begin{array}{l}\text { Methane and } \\
\text { NO }\end{array}$ & $\begin{array}{l}\text { Livesley and } \\
\text { Andrusiak, } 2011\end{array}$ \\
\hline & China & SSI & $\begin{array}{l}\text { Carbon } \\
\text { Sequestration }\end{array}$ & Lu et al. 2014 \\
\hline & Belize & $\mathrm{N}$ & $\begin{array}{l}\text { Carbon } \\
\text { Sequestration }\end{array}$ & McLeod et al. 2011 \\
\hline & $\begin{array}{l}\text { Global } \\
\text { Review }\end{array}$ & $\mathrm{N}$ & $\begin{array}{l}\text { Carbon } \\
\text { Sequestration }\end{array}$ & Polidoro et al. 2010 \\
\hline & Hawaii & ESI & $\begin{array}{l}\text { Carbon } \\
\text { Remineralizatio } \\
\mathrm{n}\end{array}$ & $\begin{array}{l}\text { Sweetman et al. } \\
2010\end{array}$ \\
\hline & $\begin{array}{l}\text { Solomon } \\
\text { Islands }\end{array}$ & $\mathrm{N}$ & $\begin{array}{l}\text { Native } \\
\text { Mangroves }\end{array}$ & $\begin{array}{l}\text { Warren-Rhodes et } \\
\text { al. } 2011\end{array}$ \\
\hline \multirow{8}{*}{ BIOREMEDIATION } & Brazil & $\mathrm{N}$ & $\mathrm{PAH}$ & Andrade et al. 2012 \\
\hline & $\begin{array}{l}\text { Mayotte Is. } \\
\text { Indian } \\
\text { Ocean }\end{array}$ & $\mathrm{N}$ & Human Waste & Bouchez et al. 2013 \\
\hline & Hawaii & ESI & Nutrients & $\begin{array}{l}\text { Fry and Cormier, } \\
2011\end{array}$ \\
\hline & $\begin{array}{l}\text { Gulf of } \\
\text { Mexico }\end{array}$ & $\mathrm{N}$ & Nutrients & Genthner et al. 2013 \\
\hline & Hawaii & ESI & Nutrients & Keala et al. 2007 \\
\hline & $\begin{array}{l}\text { Global } \\
\text { Review }\end{array}$ & $\mathrm{N}$ & Nutrients & Krauss et al. 2008 \\
\hline & Hong Kong & SSI & $\mathrm{PAH}$ & Li et al. 2009 \\
\hline & $\begin{array}{l}\text { Gulf of } \\
\text { Mexico }\end{array}$ & $\mathrm{N}$ & PAH & Santos et al. 2011 \\
\hline
\end{tabular}




\begin{tabular}{|l|l|l|l|l|} 
& $\begin{array}{l}\text { Global } \\
\text { Review }\end{array}$ & $\mathrm{N}$ & Nutrients & Walters et al. 2008 \\
\cline { 2 - 5 } & $\begin{array}{l}\text { Futian, } \\
\text { China }\end{array}$ & SSI & Human Waste & Yang et al. 2008 \\
\hline
\end{tabular}

SUPPORTING SERVICES

\begin{tabular}{|c|c|c|c|c|}
\hline \multirow{18}{*}{ BIODIVERSITY } & Hawaii & ESI & Shorebirds & Allen, 1998 \\
\hline & $\begin{array}{l}\text { Global } \\
\text { Review }\end{array}$ & $\mathrm{N}$ & Benthic Infauna & Bertness et al. 2001 \\
\hline & Hawaii & ESI & $\begin{array}{l}\text { Benthic } \\
\text { macrofauna }\end{array}$ & $\begin{array}{l}\text { Demopoulos and } \\
\text { Smith, } 2010\end{array}$ \\
\hline & $\begin{array}{l}\text { Hawaii and } \\
\text { Puerto Rico }\end{array}$ & ESI,N & $\begin{array}{l}\text { Benthic } \\
\text { macrofauna }\end{array}$ & $\begin{array}{l}\text { Demopoulos et al. } \\
2007\end{array}$ \\
\hline & Hawaii & ESI & Shorebirds & Drigot et al. 2001 \\
\hline & $\begin{array}{l}\text { Global } \\
\text { Review }\end{array}$ & ESI,N & $\begin{array}{l}\text { Mangrove } \\
\text { Predators }\end{array}$ & $\begin{array}{l}\text { Farnsworth and } \\
\text { Ellison, } 1997\end{array}$ \\
\hline & Florida & SSI & $\begin{array}{l}\text { Non-Native } \\
\text { Mangroves }\end{array}$ & $\begin{array}{l}\text { Fourqurean et al. } \\
2010\end{array}$ \\
\hline & Hawaii & ESI & Bats & Duffy et al. 2007 \\
\hline & Hawaii & ESI & Shorebirds & Garrison et al. 2002 \\
\hline & Panama & $\mathrm{N}$ & Zooplankton & $\begin{array}{l}\text { Granek and Frasier, } \\
2007\end{array}$ \\
\hline & $\begin{array}{l}\text { Is. of } \\
\text { Rodruiges } \\
\text { Indian } \\
\text { Ocean }\end{array}$ & ESI & Foraminifera & $\begin{array}{l}\text { Langer and Lipps, } \\
2006\end{array}$ \\
\hline & China & SSI & Macrofauna & $\begin{array}{l}\text { Leung and Tam, } \\
2013\end{array}$ \\
\hline & $\begin{array}{l}\text { Global } \\
\text { Review }\end{array}$ & $\mathrm{N}$ & Diverse Taxa & $\begin{array}{l}\text { Nagelkerken et al. } \\
2008\end{array}$ \\
\hline & Hawaii & ESI & Macrofauna & Nakahara, 2007 \\
\hline & $\begin{array}{l}\text { Global } \\
\text { Review }\end{array}$ & $\mathrm{N}$ & $\begin{array}{l}\text { Mangrove } \\
\text { Extinction Risk }\end{array}$ & Polidoro et al. 2010 \\
\hline & Hawaii & ESI & Waterbirds & $\begin{array}{l}\text { Rauzon and Drigot, } \\
2001\end{array}$ \\
\hline & $\begin{array}{l}\text { Southern } \\
\text { China }\end{array}$ & SSI & Invasive Plants & Ren et al. 2009 \\
\hline & Hawaii & ESI & Macrofauna & Siple and Donahue, \\
\hline
\end{tabular}




\begin{tabular}{|c|c|c|c|c|}
\hline & \multirow[b]{2}{*}{ Hawaii } & & & 2013 \\
\hline & & ESI & $\begin{array}{l}\text { Mangrove } \\
\text { Predators }\end{array}$ & Steele et al. 1999 \\
\hline & $\begin{array}{l}\text { Non-Native } \\
\text { Mangroves }\end{array}$ & ESI,N & $\begin{array}{l}\text { Mangrove } \\
\text { Fungus }\end{array}$ & $\begin{array}{l}\text { Volkmann- } \\
\text { Kohlmeyer and } \\
\text { Kohlmeyer, } 1993\end{array}$ \\
\hline & \begin{tabular}{|l|} 
Hainan \\
Province, \\
China \\
\end{tabular} & SSI & $\begin{array}{l}\text { Non-Native } \\
\text { Mangroves }\end{array}$ & Xin et al. 2013 \\
\hline \multicolumn{5}{|l|}{ CULTURAL SERVICES } \\
\hline \multirow{4}{*}{ SPIRITUAL/CULTURAL } & Hawaii & ESI & $\begin{array}{l}\text { Non-Native } \\
\text { Mangroves }\end{array}$ & Farber, 1997 \\
\hline & Hawaii & ESI & $\begin{array}{l}\text { Non-Native } \\
\text { Mangroves }\end{array}$ & Fronda et al. 2008 \\
\hline & $\begin{array}{l}\text { Global } \\
\text { Review }\end{array}$ & $\mathrm{N}$ & Mangroves & Walters et al. 2008 \\
\hline & $\begin{array}{l}\text { Solomon } \\
\text { Islands } \\
\end{array}$ & $\mathrm{N}$ & Mangroves & Warren et al. 2011 \\
\hline \multirow{3}{*}{$\begin{array}{l}\text { ECOTOURISM/RECREATI } \\
\text { ON }\end{array}$} & Iran & $\mathrm{N}$ & Mangroves & $\begin{array}{l}\text { Dehghani et al. } \\
2010\end{array}$ \\
\hline & Egypt & $\mathrm{N}$ & Mangroves & Hergazy et al. 2002 \\
\hline & Gambia & $\mathrm{N}$ & Mangroves & $\begin{array}{l}\text { Satyanarayana et al. } \\
2012\end{array}$ \\
\hline \multirow{3}{*}{ EDUCATION } & Sri Lanka & $\mathrm{N}$ & Mangroves & $\begin{array}{l}\text { Emerton and } \\
\text { Kekulandala, } 2003\end{array}$ \\
\hline & Florida & $\mathrm{N}$ & Mangroves & Finn,1996 \\
\hline & $\begin{array}{l}\text { Sundarba } \\
\text { ns India }\end{array}$ & $\mathrm{N}$ & Mangroves & $\begin{array}{l}\text { Sarkar and } \\
\text { Bhattacharya, } 2003\end{array}$ \\
\hline \multirow{4}{*}{ Social Capital } & Hawaii & ESI & Mangroves & Farber, 1997 \\
\hline & Hawaii & ESI & Mangroves & Kobsa, 2010 \\
\hline & Fiji & $\mathrm{N}$ & Mangroves & O’Garra, 2012 \\
\hline & Columbia & $\mathrm{N}$ & Mangroves & Vilardy et al. 2011 \\
\hline
\end{tabular}




\begin{tabular}{|c|c|c|c|c|}
\hline \multirow{9}{*}{ Multiple Categories } & $\begin{array}{l}\text { Global } \\
\text { Review }\end{array}$ & $\mathrm{N}$ & $\begin{array}{l}\text { Mangrove } \\
\text { Conservation }\end{array}$ & Alongi, 2002 \\
\hline & $\begin{array}{l}\text { Global } \\
\text { Review }\end{array}$ & $\mathrm{N}$ & $\begin{array}{l}\text { Mangrove } \\
\text { Valuation }\end{array}$ & Barbier et al.2011 \\
\hline & $\begin{array}{l}\text { Global } \\
\text { Review }\end{array}$ & $\mathrm{N}$ & $\begin{array}{l}\text { Mangrove } \\
\text { Valuation }\end{array}$ & Brander et al. 2006 \\
\hline & $\begin{array}{l}\text { Global } \\
\text { Review }\end{array}$ & $\mathrm{N}$ & $\begin{array}{l}\text { Mangrove } \\
\text { Valuation }\end{array}$ & $\begin{array}{l}\text { Conservation } \\
\text { International, } 2008 \\
\end{array}$ \\
\hline & $\begin{array}{l}\text { Mumbai, } \\
\text { India }\end{array}$ & $\mathrm{N}$ & Multiple ES & Everard et al. 2014 \\
\hline & $\begin{array}{l}\text { Global } \\
\text { Review }\end{array}$ & $\mathrm{N}$ & Multiple & MEA, 2005 \\
\hline & $\begin{array}{l}\text { South China } \\
\text { Sea }\end{array}$ & $\mathrm{N}$ & $\begin{array}{l}\text { Mangrove } \\
\text { Valuation }\end{array}$ & Pernetta et al. 2013 \\
\hline & $\begin{array}{l}\text { Global } \\
\text { Review }\end{array}$ & $\mathrm{N}$ & $\begin{array}{l}\text { Mangrove } \\
\text { Valuation }\end{array}$ & $\begin{array}{l}\text { Salem and Mercer, } \\
2012\end{array}$ \\
\hline & $\begin{array}{l}\text { Global } \\
\text { Review }\end{array}$ & $\mathrm{N}$ & $\begin{array}{l}\text { Mangrove } \\
\text { Valuation }\end{array}$ & Vo et al. 201 \\
\hline
\end{tabular}




\section{APPENDIX 3 \\ Paths for Future Research:}

Selected figures from the United Nation Environmental Programme (UNEP) report titled Pacific Island Mangroves in a Changing Climate and Rising Sea (Gilman et al. 2006) are presented below and hyperlinked for convinient reference under Literature Cited. This map, in particular, shows the total diversity of mangroves in Oceania, including where genetic hybrids have been detected (Figure 3). This report illustrates the lack of historical data in the Marshall Islands in particular; highlighted again by their Figure 17 and Table (A)2 presented below for convienient reference. This report demonstrates the potential to expand basic science and fill information gaps that are easily identified relating to mangrove population dynamics in the Republic of the Marshall Islands specifically.

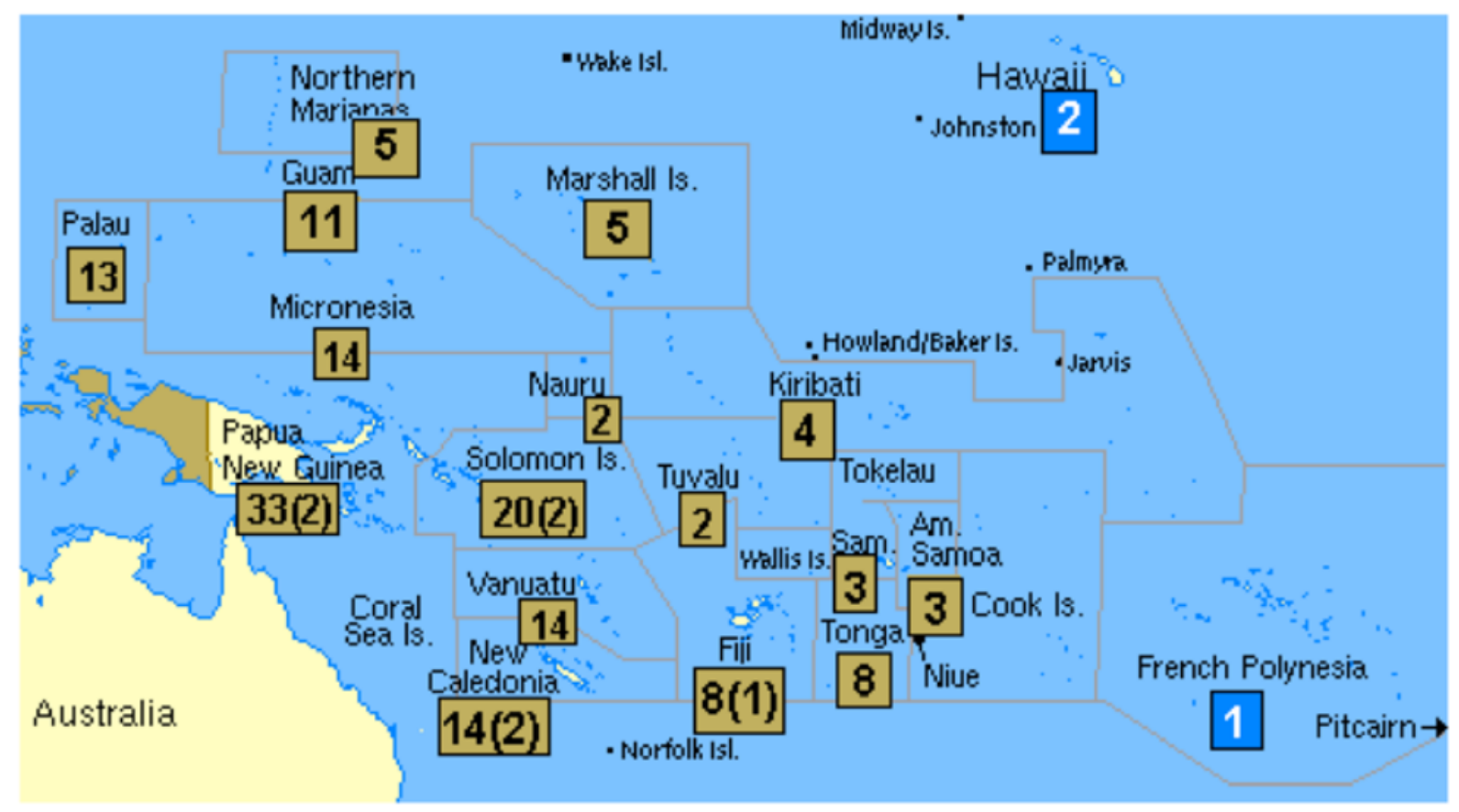

Fig. 3. Mangrove species distributions in the Pacific Islands region (Ellison, 1995). Yellow squares give the number of mangrove species in the 16 countries and territories where mangroves are indigenous, blue squares are the two locations where mangroves are human-introductions. The number of mangrove hybrid species is in parentheses. 
Table (A) 2 shows a listing of the historic records indicate the great deficiency in mangrove knowledge in the RMI. The RMI has made great progress in addressing climate change threats in recent years, however, and many grassroots organizations may already be filling some of these knowledge gaps at the present. None-the-less, the paucity of mangrove research in the Marshall Islands make it exceptionally positioned for adaptive management plans to begin collecting baseline data for more long term ecological research on places like Namdrik and Jaluit atolls which have the community partners and political support ready to assist future researchers.

Table 2. Summary of technical and institutional capacity of ten Pacific Island countries and territories with indigenous mangroves to assess vulnerability and adapt to mangrove responses to relative sea level and climate change.

\begin{tabular}{|c|c|c|c|c|c|c|c|c|c|c|}
\hline \multirow{2}{*}{$\begin{array}{c}\text { Technical and } \\
\text { Institutional } \\
\text { Capacity Attribute }\end{array}$} & \multicolumn{10}{|c|}{ Country or Territory } \\
\hline & $\begin{array}{l}\text { American } \\
\text { Samoa }\end{array}$ & $\mathrm{F}_{\mathrm{i}}$ & Kiribati & $\begin{array}{l}\text { Marshall } \\
\text { Islands }\end{array}$ & $\begin{array}{l}\text { Federated } \\
\text { States of } \\
\text { Micronesia }\end{array}$ & $\begin{array}{l}\text { Northern } \\
\text { Mariana } \\
\text { Islands }\end{array}$ & Palay & $\begin{array}{c}\text { Papua New } \\
\text { Guinea }\end{array}$ & Tonga & Vanuatu \\
\hline $\begin{array}{l}\text { Length of tide gauge } \\
\text { record through Dec. } \\
2005 \text { (years) }\end{array}$ & 56.2 & 31.2 & 11.0 & 58.5 & 47.7 & 23.1 & 33.8 & 39.7 & 13.4 & 10.9 \\
\hline $\begin{array}{l}\text { Largest distance } \\
\text { between tide gauge and } \\
\text { mangrove }(\mathrm{km})\end{array}$ & 6.5 & 800 & $\begin{array}{c}\text { Not } \\
\text { known }\end{array}$ & $\begin{array}{c}\text { Not } \\
\text { known }\end{array}$ & 563 & 10 & 700 & 500 & 17 & $\begin{array}{c}\text { Not } \\
\text { known }\end{array}$ \\
\hline $\begin{array}{l}\text { Percent of mangrove } \\
\text { boundaries delineated } \\
\text { and mapped }\end{array}$ & 100 & 80 & 22 & 0 & 21 & 100 & 99 & $\begin{array}{c}\text { Not } \\
\text { known }\end{array}$ & 90 & 0 \\
\hline $\begin{array}{l}\text { Year of most recent } \\
\text { mangrove boundary } \\
\text { survey }\end{array}$ & 2002 & 1983 & 1998 & $\begin{array}{c}\text { Not } \\
\text { applicable }\end{array}$ & 2002 & 1989 & 1971 & 1993 & 2000 & $\begin{array}{c}\text { Not } \\
\text { applicable }\end{array}$ \\
\hline $\begin{array}{l}\text { Percent of mangrove } \\
\text { islands with topographic } \\
\text { map coverage }\end{array}$ & 100 & 100 & 22 & 0 & 100 & 100 & 87.5 & 86 & 0 & 100 \\
\hline $\begin{array}{l}\text { Percent of mangrove } \\
\text { islands with maps } \\
\text { showing buildings, roads, } \\
\text { and other development }\end{array}$ & 100 & 100 & 25 & 20 & 100 & 100 & 0 & 0 & 33 & 100 \\
\hline $\begin{array}{l}\text { Year of most current } \\
\text { map showing location of } \\
\text { development: }\end{array}$ & 2001 & 1983 & 1998 & 2004 & 2004 & 1999 & $\begin{array}{c}\text { Not } \\
\text { applicable }\end{array}$ & NA & 1998 & $\begin{array}{c}\text { Not } \\
\text { known }\end{array}$ \\
\hline $\begin{array}{l}\text { Date pf earliest imagery } \\
\text { showing mangrove } \\
\text { margin (aerial photos, } \\
\text { satellite magery, maps) }\end{array}$ & 1961 & 1954 & 1960 & 2004 & 1944 & 1940 & 1946 & 1971 & 1995 & 1980 \\
\hline $\begin{array}{l}\text { Have mangrove } \\
\text { sediment erosion/ } \\
\text { accretion rates been } \\
\text { measured? }\end{array}$ & Yes & No & No & No & Yes & No & No & No & No & No \\
\hline $\begin{array}{l}\text { Is there a mangrove } \\
\text { monitoring program }\end{array}$ & Yes & Yes & No & No & Yes & No & No & No & Yes & No \\
\hline $\begin{array}{l}\text { Is there in-country staff } \\
\text { with skills to conduct } \\
\text { mangrove surveys and } \\
\text { inventories? }\end{array}$ & Yes & Yes & Yes & Yes & Yes & Yes & Yes & Yes & Yes & No \\
\hline $\begin{array}{l}\text { Have mangroves been } \\
\text { successfuly } \\
\text { rehabilitated?" }\end{array}$ & No & $\begin{array}{c}\text { Not } \\
\text { known }\end{array}$ & Yes & No & No & Yes & Yes & No & Yes & No \\
\hline $\begin{array}{l}\text { Is there a permit or } \\
\text { zoning program for } \\
\text { coastal development? }\end{array}$ & Yes & Yes & Yes & Yes & Yes & Yes & Yes & Yes & Yes & Yes \\
\hline $\begin{array}{l}\text { Has there been ste- } \\
\text { specific mangrove } \\
\text { vulnerability } \\
\text { assessments? }\end{array}$ & Yes & No & No & No & No & No & No & No & No & No \\
\hline $\begin{array}{l}\text { Is there a plan for } \\
\text { adaptaxion to coastal } \\
\text { ecosystem responses to } \\
\text { climate change effects? }\end{array}$ & No & No & No & No & No & No & No & No & No & No \\
\hline
\end{tabular}

